Uirá Souto Melo

Desvendando as bases moleculares da síndrome SPOAN: deleção em homozigose em região regulatória leva à superexpressão do gene $K L C 2$

Unraveling the molecular basis of SPOAN syndrome: deletion in homozygosis in regulatory region leads to KLC2 gene overexpression

São Paulo

2016 


\section{Uirá Souto Melo}

Desvendando as bases moleculares da síndrome SPOAN: deleção em homozigose em região regulatória leva à superexpressão do gene $K L C 2$

Unraveling the molecular basis of SPOAN syndrome: deletion in homozygosis in regulatory region leads to $K L C 2$ gene overexpression

Tese apresentada ao Instituto de Biociências da Universidade de São Paulo, para a obtenção de Título de Doutor em Ciências, na Área de Genética e Biologia Evolutiva.

Orientador(a): Fernando Kok

Co-orientador(a): Silvana Santos

VERSÃO CORRIGIDA - O original encontra-se disponível no Instituto de Biociências da USP.

São Paulo 


\section{Ficha Catalográfica}

Souto Melo,Uirá

Desvendando as bases moleculares da síndrome SPOAN: deleção em homozigose em região regulatória leva à superexpressão do gene KLC2

80 páginas

Tese (Doutorado) - Instituto de Biociências da Universidade de São Paulo. Departamento de Genética e Biologia Evolutiva.

1. Palavra-Chave Principal - Síndrome SPOAN 2. Palavra-Chave Secundária - Paraplegia espástica 3. Palavra-Chave Secundária - KLC2 4. Palavra-Chave Secundária - Estudo funcional Universidade de São Paulo. Instituto de Biociências. Departamento de Genética e Biologia Evolutiva.

\section{Comissão Julgadora:}

Prof(a). Dr(a).

Prof(a). Dr(a).
Prof(a). Dr(a).

Prof(a). Dr(a).

Prof(a). Dr(a). Fernando Kok

Orientador(a) 


\section{Epígrafe}

Se avexe não...

Amanhã pode acontecer tudo

Inclusive nada

Se avexe não... A lagarta rasteja até o dia

Em que cria asas

Se avexe não... Que a burrinha da felicidade

Nunca se atrasa

Se avexe não... Amanhã ela pára na porta

Da sua casa

Se avexe não...

Toda caminhada começa

No primeiro passo

A natureza não tem pressa

Segue seu compasso

Inexoravelmente chega lá

(...)

Flávio José, A Natureza das Coisas 


\section{Agradecimentos}

Ao meu orientador Prof. Dr. Fernando Kok, por toda a dedicação, amizade, carinho e presteza durante o período de orientação.

À minha eterna "comadre" e co-orientadora Profa. Dra. Silvana Santos, a ela dedico toda minha vida científica.

À minha "ex" mãe científica e eterna colaboradora Profa. Dra. Regina Célia Mingroni Netto e ao excelentíssimo Prof. Dr. Paulo Otto. Agradeço também aos professores Ângela Morgante, Luciana Haddad, Maria Rita Passos Bueno e Merari Ferrari pela oportunidade de aprendizado e discussão sobre ciência. Em especial, agradeço à Profa. Dra. Mayana Zatz pela oportunidade de realizar os experimentos do doutorado em seu laboratório.

Ao Ph.D. Len Pennacchio por ter me recebido no seu laboratório situado na cidade de Berkeley, Estados Unidos, durante meu período de "doutorado-sanduíche”. Também agradeço aos grandes amigos do laborátorio nos EUA: Iros Barrozi, Evgeny Kvon, Remo Monti, Marco Osterwalder, Cailyn Spurrel, Brandon Manion entre outros. Em especial, agradeço a Lindsay Capellot pela companhia e por todo carinho que me deu durante os meses nos EUA.

À Dra. Nora Calcaterra por ter me recebido tão bem em seu laboratório em Rosário, na Argentina. À todos os integrantes desse laboratório, em especial à Ezequiel Margarit, Valeria Mouguelar, Pablo Armas, Gabi Coux, Aldana David e Sofia Heckell. Meus sinceros agradecimentos pela hospitalidade, ajuda e companhia.

Aos bons e velhos amigos do Laboratório de Genética Humana: Leandro Ucela, Dayane Cruz, Ana Carla Batissoco, Lilian Kimura, Renan Lemos, Rodrigo Salazar, Juliana Prior, Teresa Balester. Às minhas queridas amigas Fátima Caly e Maria Raimunda do laboratório da Professora Ângela Morgante, as quais foram pessoas essenciais na minha formação e convivência dentro do espaço da USP. Também agradeço a companhia de Maraísa Sebastião e Paulo Rogério, dois grandes amigos que lembrarei sempre com muito carinho.

Aos grandes amigos do Laboratório de Evolução Humana coordenado pelo querido Prof. Dr. Walter Neves e pelo Prof. Dr. Rui Murrieta, a quem tenho enorme admiração. Agradeço também a amizade dos alunos desse laboratório, em especial ao conterrâneo Carlos Frederico e à Mariana Inglez. 


\section{Agradecimentos}

Aos bons e novos amigos do Laboratório de Doenças Neuromusculares: Melinda Beccari, Naila Lourenço, Antônia Cerqueira, Luiz Caires, Ernesto Goulart, Thiago Rosa, Lucia Inês Macedo Souza, Danyllo Oliveira, Bruno Ghirotto, Giovanna Pontillo, Carolina Rauffus, Gabriel Lauria, Bárbara Bischain e Lucas Leite. Aos bons amigos e colegas do Laboratório de Genética do Desenvolvimento (vulgo sala 200): Carol Malcher, Lucas Alvizi, Roberto Fanganiello, Bela Mayá, Luciano Abreu, Felipe Ishy, Simone Gomes, Gerson Kobayashi, Duda Morgana entre vários outros. Agradeço em especial ao Dr. João Kitajima por todas as trocas de conversa e discussão sobre temas relacionados à bioinformática.

À todos os participantes do NEGE da Universidade Estadual da Paraíba, entre eles: Thalita Figueiredo, Thiago Pequeno, Aluska Matias, Prof. Dr. Mathias Weller, Roberta Smania, Karol Souza, Fernando Lopes entre outros que participaram ativamente da construção do NEGE.

À minha família paulistana, amigos que a vida me apresentou no primeiro ano de residência em São Paulo e que me acompanharam por toda minha trajetória. Agradeço enormemente a vocês: Fernando Mouron, Erika Jessica Maria Alexandra Medina Barrantes, Matheus Soldi Hardt, Francisco Urdinez, Lucio Salles e Alysson Morais.

Aos eternos amigos do curso de Biologia 2006.2 da Universidade Estadual da Paraíba: Mariana Fragoso, Ribamar Lima, Thiago Severo, Magna Barbosa, Fernanda Brito, Ana Amélia Calazans, Daniela Lima e Emmannuel Duarte. Em especial, agradeço a super amizade do meu querido e eterno companheiro Allysson Allan de Farias.

Aos meus pais, Fabíola e Josemir, pelo apoio psicológico, emocional e financeiro. Aos meus irmãos Cauê, Tainá e Anaíra pelo prazer da convivência. À minha avó, aos meus tios e tias, primos e primas. À todos os meus amigos queridos: Edilson Junior, Thiago Alcântara, Felicio Queiroz, Filipi Freire, Jalmair Araújo, Yury Frederico, Felipe Vasconcelos, Fagner Melo, Luciano Lonegro, dentre muitos outros.

Aos pacientes que aceitaram participar deste projeto de pesquisa.

À CAPES pela bolsa de doutorado e "doutorado-sanduíche" concedidas.

À FAPESP pelo auxílio financeiro à realização dos experimentos. 


\section{Índice}

Apresentação da tese de doutorado 1

Resumo 3

Abstract 4

1. Introdução 5

1.1. Paraplegias espásticas hereditárias 5

1.2. Transporte axonal 9

1.3. Cinesinas 12

1.4. Doenças neurodegenerativas associadas ao defeito de transporte axonal 15

$\begin{array}{ll}\text { 1.5. Modelos animais de neurodegeneração } & 16\end{array}$

$\begin{array}{lr}\text { 1.6. Síndrome SPOAN } & 19\end{array}$

1.7. Objetivos 22

1.7.1. Objetivos específicos 22

2. Materias e métodos 23

2.1. Casuística 23

2.2. Estudo molecular realizado no laboratório de doenças neuromusculares do Instituto de Biociências da Universidade de São Paulo 24

2.2.1. Sequenciamento de nova geração e estudo de segregação das variantes 24

2.2.2. Extração de RNA, cDNA e PCR em tempo real (qRT-PCR) 25

2.3. Colaboração com outros centros de pesquisa 26

2.4. Modelo animal de zebrafish 27

2.4.1. Extração de RNA de zebrafish e cDNA 27

2.4.2. Clonagem dos cDNAs do klc2 em plasmídeos 28

2.4.3. Estudo de knockdown do klc2 em zebrafish 30

2.4.4. Superexpressão do $k l c 2$ e resgate de fenótipo em zebrafish 31

2.4.5. Whole-mount in situ hybridization (WISH) 31

2.5. Metodologia do uso do modelo animal de camundongo 32

2.5.1. Plasmídeos e ensaio de gene reporter por LacZ 32

2.5.2. Superexpressão do gene $K L C 2$ humano em camundongo 33 


\section{Índice}

3. Resultados e discussão 35

3.1. Identificação da variante patogênica associada à síndrome SPOAN 35

3.2. Artigo publicado na revista Human Molecular Genetics 38

3.3. Resultados do experimento de WISH em zebrafish 55

3.4. Ensaios realizados em modelo de camundongo 56

3.4.1. Resultados do gene reporter LacZ em embriões de camundongo 57

3.4.2. Superexpressão do KLC2 humano em camundongo 59

3.4.2.1. Camundongos da geração F0 60

3.4.2.2. Camundongos da geração F1 63

4. Considerações finais e perspectivas futuras 68

5. Referências 71 


\section{Índice de Tabelas}

Tabela 1. Loci e genes relacionados às HSPs.................................. 6

Tabela 2. Ortólogos de zebrafish associados à HSPs em Homo sapiens................ 17

Tabela 3. Sequência dos primers utilizados para a amplificação do cDNA do klc2....... 30

Tabela 4. Primers utilizados no estudo de camundongos transgênicos................ 34

Tabela 5. Variantes detectadas em homozigose pelo WES na região cromossômica ligada

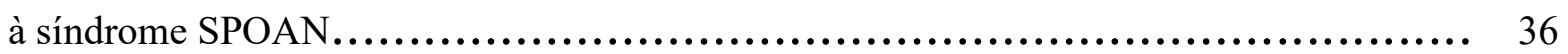




\section{Índice de Figuras}

Figura 1. Representação estrutural das cinesinas e dineínas, e o sentido de locomocação dessas proteínas motoras em relação a polarização do microtúbulo.

Figura 2. As estruturas denominadas de head, neck, stalk e tail são estruturas representativas das KHCs................................................................ 13

Figura 3. A região tetratricopeptídeo (TRP) coiled-coil, que tem como função o reconhecimento de cargas específicas a serem transportadas pela cinesina.................. 14

Figura 4. Genealogia de um grande núcleo familiar da síndrome SPOAN do estado do Rio Grande do Norte........................................................................... 20

Figura 5. Sequência do plasmídeo pCS2+MT com o cDNA do eGFP fusionado............ 29

Figura 6. Padrão de expressão do $k l c 2$ por meio de WISH em embriões no estágio de 4 a 8 células $(\mathrm{a}, \mathrm{c})$ e embriões no estágio de 15 a 20 somitos $(\mathrm{b}, \mathrm{d}, \mathrm{e}, \mathrm{f})$............................... 55

Figura 7. Padrão de expressão do $k l c 2$ por meio de WISH em embriões no estágio de 48hpf $(\mathrm{a}, \mathrm{b}, \mathrm{c}, \mathrm{d})$ e embriões no estágio de $72-\mathrm{hpf}(\mathrm{e}, \mathrm{f})$.......................................... $\quad 56$

Figura 8. Expressão do LacZ em embriões no estágio e.15.5 usando a construção da região regulatória wild-type......................................................................... 58

Figura 9. Expressão do LacZ em embriões no estágio e.15.5 usando a construção da região regulatória com a deleção de $216-$ pb.............................................. 59

Figura 10. Esquematização da localização dos amplicons da PCR no Fosmídeo............ 60

Figura 11. qPCR mostrando o número de cópias do KLC2 humano inseridos no genoma de camundongos da linhagem F0

Figura 12. Gráficos mostrando a avaliação do peso dos camundongos transgênicos e controles durante sete semanas....................................................................

Figura 13. qRT-PCR usando cDNA de cérebro de camundongos transgênicos coletados no estágio de P10 comparados com o mesmo tecido de camundongos wild-type, pareados para a mesma ninhada.

Figura 14. Genealogia dos camundongos e resultado do qPCR mostrando o número de cópias do $K L C 2$ humano nos camundongos transgênicos da geração $\mathrm{F} 1$

Figura 15. Genealogia simples e qPCR mostrando o número de cópias do KLC2 humano nos camundongos transgênicos da geração F2................................................... 


\section{Apresentação da tese de doutorado}

A síndrome SPOAN é uma doença neurodegenerativa de herança autossômica recessiva pertencente ao grande grupo das paraplegias espásticas hereditárias (HSP). As HSPs são um grupo nas quais os pacientes apresentam espasticidade progressiva e fraqueza dos membros inferiores. Até o presente momento mais de 70 loci foram associados à HSP e em mais da metade o gene associado à condição foi identificado. SPOAN é o acrônimo dos principais sinais clínicos, em inglês spastic paraplegia, optic atrophy and neuropathy.

O estudo clínico e genético de indivíduos com a síndrome SPOAN vêm sido realizado no Centro de Estudos do Genoma Humano (CEGH) do Instituto de Biociências da Universidade de São Paulo (USP) desde 2003 sob coordenação da Profa. Dra. Mayana Zatz e do Prof. Dr. Fernando Kok. A casuística foi identificada durante o doutoramento da Profa. Dra. Silvana Santos, hoje docente da Universidade Estadual da Paraíba (UEPB), e foi avaliada clinicamente pela equipe do Prof. Dr. Fernando Kok do Departamento de Neurologia da Faculdade de Medicina da USP (FMUSP). A descrição clínica e genética inicial dessa síndrome foi realizada durante a tese de doutoramento da Dra. Lucia Inês Macedo Souza.

Ao longo do período de dez anos foram identificadas mais de 70 pessoas afetadas com a síndrome SPOAN, oriundas da região do interior do estado do Rio Grande do Norte. Além desse grande cluster, outros três pacientes sem parentesco com os pacientes da região do Rio Grande do Norte também foram diagnosticados com essa síndrome, sendo esses oriundos dos estados de Minas Gerais e Rio Grande do Sul. Em colaboração com Joseph Gleeson, MD, Ph.D., do laboratório de neurogenética da University of California, San Diego, identificamos mais dois pacientes egípcios (irmãos) com essa doença.

Nessa tese de doutorado foram realizados estudos genômicos e funcionais para identificar e avaliar a patogenicidade da variante associada à síndrome SPOAN. A introdução da tese é uma 
revisão da literatura sobre paraplegias espásticas hereditárias, sobre o tráfego de vesículas axonal, sobre as proteínas motoras cinesinas, doenças neurodegenerativas associadas ao defeito de transporte axonal e sobre a síndrome SPOAN. A seção de materiais e métodos apresenta todas as técnicas e procedimentos realizados dos estudos genéticos e funcionais desta tese. A seção dos resultados e discussão consiste na descrição da variante patogênica associada ao fenótipo e estudos funcionais em modelos in vitro e in vivo. Nessa seção também se encontra o artigo originado desta tese, na íntegra, com título "Overexpression of KLC2 due to a homozygous deletion in the non-coding region causes SPOAN syndrome", publicado no periódico internacional Human Molecular Genetics (A1 para área de Genética). Para finalizar, a última seção da tese discerne sobre as considerações finais e perspectivas futuras reune os principais achados experimentais dessa tese de doutoramento e as possíveis novas estratégias para continuar a investigação do mecanismo patofisiológico da síndrome SPOAN. 


\section{Resumo}

A síndrome SPOAN (acrônimo do inglês spastic paraplegia, optic atrophy and neuropathy) é uma doença neurodegenerativa de herança autossômica recessiva que tem como achados clínicos a atrofia ótica congênita não progressiva, paraplegia espástica e neuropatia ambas progressivas. Ela havia sido mapeada na região cromossômica 11q13, porém a variante patogênica e o gene associados à síndrome não haviam sido identificados. Após execução do sequenciamento do genoma completo de um paciente foi detectada a deleção de 216-pb (chr11.hg19:g.66,024,557_66,024,773del) em homozigose localizada em região regulatória upstream do gene $K L C 2$. Surpreendentemente, essa deleção causa superexpressão do $K L C 2$, detectada em estudos de Real-Time Quantitative Reverse Transcription PCR (qRT-PCR) utilizando fibroblastos e neurônios motores de pacientes comparados com controles. Ensaios utilizando o Danio rerio como modelo in vivo mostraram que tanto o knockdown quanto a superexpressão do klc2 em embriões de zebrafish causa o fenótipo de cauda curvada (leve ou grave); fenótipo esse associado às doenças neurodegenerativas e HSPs. Superexpressão de um gene causada por uma pequena deleção em região regulatória é um novo mecanismo que até então não havia sido descrito na condição autossômica recessiva. Estudos funcionais por meio de gene reporter de LacZ avaliando o padrão de expressão espaço-temporal da região regulatória wild-type e com a deleção de 216-pb foram realizados nesse trabalho em modelo de camundongo, porém, não foi possível identificar um padrão de expressão reprodutível do gene reporter nesse modelo. Por fim, camundongos transgênicos para a superexpresão do $K L C 2$ humano foram gerados, no entanto não foram realizados testes físicos e comportamentais para validar o transgênico como modelo para síndrome SPOAN. 


\begin{abstract}
SPOAN (the acronym of its clinical symptoms) syndrome is a neurodegenerative disorder mainly characterized by a progressive spastic paraplegia, congenital non-progressive optic atrophy and progressive neuropathy. A potential causative gene was mapped at 11q13, but so far no gene and mutation were identified. Whole-genome sequencing allowed to detect a homozygous 216-bp deletion (chr11.hg19:g.66,024,557_66,024,773del) located at the regulatory upstream region of the $K L C 2$ gene. Surprisingly, this deletion causes $K L C 2$ overexpression detected by Real-Time Quantitative Reverse Transcription PCR (qRT-PCR) using fibroblasts and motor-neurons from patients compared with controls. Assays using Danio rerio as in vivo model showed that the klc2 knockdown either its overexpression in zebrafish embryos causes mild to severe curly-tail phenotype; phenotype that is already well defined as suggestive of a neurodegenerative disorder and HSP. Overexpression of a gene caused by a small deletion in the regulatory region is a novel mechanism, which to the best of our knowledge, was never reported before in a recessive condition. Functional studies using LacZ reporter assay evaluating the spatiotemporal expression pattern of wild-type regulatory region and with the deletion of 216-bp were performed in this work using mouse, but was not possible to identify an especific gene reporter expression pattern in this animal model. As a last experiment, transgenic mice for human $K L C 2$ overexpression were generated, though behavioral tests were not performed to validate this transgenic animal as a model for SPOAN syndrome.
\end{abstract}




\section{Introdução}

\subsection{Paraplegias espásticas hereditárias}

As paraplegias espásticas hereditárias (HSPs, do inglês hereditary spastic paraplegia) são um grupo diverso de doença genética neurodegenerativa caracterizadas por fraqueza muscular e rigidez progressiva nas extremidades inferiores que resultam da degeneração dos axônios dos neurônios motores superiores (Blackstone et al., 2011; Schule \& Schols, 2011). Com base na presença ou ausência de outros distúrbios neurológicos, as HSPs são classificadas como não complicadas (puras) e complicadas, respectivamente. As HSPs não complicadas têm como achados clínicos apenas a paraparesia progressiva, fraqueza muscular e espasticidade nos membros inferiores. As HSPs complicadas podem apresentar, além das características citadas acima, outros quadros clínicos como surdez, ataxia, retardo mental, sinais extrapiramidais, distúrbios visuais e epilepsia. As HSPs são geralmente progressivas e apresentam idade de início de manifestação muito variável.

A heterogeneidade de apresentação clínica é acompanhada pela heterogeneidade genética. Até o presente, mais de 70 loci, que incluem quase todos os mecanismos de herança, foram associados às HSPs (Blackstone et al., 2011; Schule \& Schols, 2011; Fink, 2006; Salinas et al., 2008; Ikenaka et al., 2012; Finsterer et al., 2012; Millecamps \& Julien, 2013; Lo Giudice et al., 2014). Os casos de HSP apresentam transmissão de herança compatível com autossômico recessivo (AR), autossômico dominante (AD) ou ligado ao cromossomo X. Os loci associados às HSPs recebem o nome de SPG e foram descritos na Tabela 1. Até o presente momento, a maioria dos loci associados à HSP teve a identidade do gene e a variante patogência causadora da doença elucidadas. 
Tabela 1. Locus e genes relacionados às HSPs. Fonte: OMIM, 2016; Finsterer et al., 2012; Millecamps \& Julien, 2013; Novarino et al., 2014; Halevy et al., 2014; Lo Giudice et al., 2014.

\begin{tabular}{|c|c|c|c|c|}
\hline Locus & Definição & Transmissão & Região & Gene \\
\hline SPG1 & Paraplegia espástica 1 & Ligada ao X Recessiva & $\mathrm{Xq} 28$ & LICAM \\
\hline SPG2 & Paraplegia espástica 2 & Ligada ao cromossomo $\mathrm{X}$ & $\mathrm{Xq} 22.2$ & $P L P 1$ \\
\hline SPG3A & Paraplegia espástica 3 & Autossômica Dominante & $14 \mathrm{q} 22.1$ & ATL1 \\
\hline SPG4 & Paraplegia espástica 4 & Autossômica Dominante & $2 \mathrm{p} 22.3$ & SPAST \\
\hline SPG5A & Paraplegia espástica 5 & Autossômica Recessiva & $8 \mathrm{q} 12.3$ & CYP7B1 \\
\hline SPG5B & Paraplegia espástica 5B & Autossômica Recessiva & - & - \\
\hline SPG6 & Paraplegia espástica 6 & Autossômica Dominante & $15 \mathrm{q} 11.2$ & NIPA1 \\
\hline SPG7 & Paraplegia espástica 7 & Autossômica Recessiva & $16 \mathrm{q} 24.3$ & $S P G 7$ \\
\hline SPG8 & Paraplegia espástica 8 & Autossômica Dominante & $8 \mathrm{q} 23-\mathrm{q} 13$ & KIAA0196 \\
\hline SPG9 & Paraplegia espástica 9 & Autossômica Dominante & 10q23.3-24.1 & - \\
\hline SPG10 & Paraplegia espástica 10 & Autossômica Dominante & $12 \mathrm{q} 13.3$ & KIF5A \\
\hline SPG11 & Paraplegia espástica 11 & Autossômica Recessiva & $15 \mathrm{q} 21.1$ & SPG11 \\
\hline SPG12 & Paraplegia espástica 12 & Autossômica Dominante & $19 q 13.32$ & RTN2 \\
\hline SPG13 & Paraplegia espástica 13 & Autossômica Dominante & 2q24-q34 & SSPD1 \\
\hline SPG14 & Paraplegia espástica 14 & Autossômica Recessiva & $3 q 27-q 28$ & - \\
\hline SPG15 & Paraplegia espástica 15 & Autossômica Recessiva & $14 q 24.1$ & ZFYVE26 \\
\hline SPG16 & Paraplegia espástica 16 & Ligada ao $\mathrm{X}$ & Xq11.2 & SPG16 \\
\hline SPG17 & Paraplegia espástica 17 & Autossômica Dominante & $11 q 12-q 14$ & $B S C L 2$ \\
\hline SPG18 & Paraplegia espástica 18 & Autossômica Recessiva & $8 \mathrm{p} 11.23$ & ERLIN2 \\
\hline SPG19 & Paraplegia espástica 19 & Autossômica Dominante & $9 \mathrm{q}$ & - \\
\hline SPG20 & Síndrome de Troyer & Autossômica Recessiva & $13 \mathrm{q} 13.3$ & $S P G 20$ \\
\hline SPG21 & Paraplegia espástica 21 & Autossômica Recessiva & $15 \mathrm{q} 21$ & $S P G 21$ \\
\hline SPG22 & Paraplegia espástica 22 & Ligada ao $\mathrm{X}$ & Xq21 & SLC16A2 \\
\hline SPG23 & Paraplegia espástica 23 & Autossômica Recessiva & 1q24-q32 & - \\
\hline SPG24 & Paraplegia espástica 24 & Autossômica Recessiva & $13 q 14$ & - \\
\hline SPG25 & Paraplegia espástica 25 & Autossômica Recessiva & $6 q 23-q 24.1$ & - \\
\hline SPG26 & Paraplegia espástica 26 & Autossômica Recessiva & 12 p11.1-q14 & $B 4 G A L N T 1$ \\
\hline SPG27 & Paraplegia espástica 27 & Autossômica Recessiva & $10 q 22.1-q 24.1$ & ENTPD1 \\
\hline SPG28 & Paraplegia espástica 28 & Autossômica Recessiva & $14 q 22.1$ & DDHD1 \\
\hline SPG30 & Paraplegia espástica 30 & Autossômica Recessiva & $2 q 37.3$ & KIF $1 A$ \\
\hline SPG31 & Paraplegia espástica 31 & Autossômica Dominante & 2p11.2 & REEP1 \\
\hline SPG32 & Paraplegia espástica 32 & Autossômica Recessiva & $14 q 12-q 21$ & - \\
\hline SPG33 & Paraplegia espástica 33 & Autossômica Dominante & $10 \mathrm{q} 24.2$ & ZFYVE27 \\
\hline SPG34 & Paraplegia espástica 34 & Ligada ao $\mathrm{X}$ & Xq24-q25 & - \\
\hline SPG35 & Paraplegia espástica 35 & Autossômica Recessiva & $16 q 23.1$ & $F A 2 H$ \\
\hline SPG36 & Paraplegia espástica 36 & Autossômica Dominante & $12 \mathrm{q} 23-\mathrm{q} 24$ & - \\
\hline SPG37 & Paraplegia espástica 37 & Autossômica Dominante & $8 \mathrm{p} 21.1-\mathrm{q} 13.3$ & - \\
\hline
\end{tabular}


Continuação da Tabela 1. Locus e genes relacionados às HSPs. Fonte: OMIM, 2016; Finsterer et al., 2012; Millecamps \& Julien, 2013; Novarino et al., 2014; Halevy et al., 2014; Lo Giudice et al., 2014.

\begin{tabular}{|c|c|c|c|c|}
\hline Locus & Definição & Transmissão & Região & Gene \\
\hline SPG38 & Paraplegia espástica 38 & Autossômica Dominante & $4 p 16-p 15$ & - \\
\hline SPG39 & Paraplegia espástica 39 & Autossômica Recessiva & $19 \mathrm{p} 13.2$ & PNPLA6 \\
\hline SPG40 & Paraplegia espástica 40 & Autossômica Dominante & - & - \\
\hline SPG41 & Paraplegia espástica 41 & Autossômica Dominante & $11 \mathrm{p} 14.1-\mathrm{p} 11.2$ & - \\
\hline SPG42 & Paraplegia espástica 42 & Autossômica Dominante & $3 q 25.31$ & SLC33A1 \\
\hline SPG43 & Paraplegia espástica 43 & Autossômica Recessiva & 19p13.11-q12 & C19orf12 \\
\hline SPG44 & Paraplegia espástica 44 & Autossômica Recessiva & $1 \mathrm{q} 42.13$ & GJC2 \\
\hline SPG45 & Paraplegia espástica 45 & Autossômica Recessiva & $10 \mathrm{q} 24.3-\mathrm{q} 25.1$ & ERLINI \\
\hline SPG46 & Paraplegia espástica 46 & Autossômica Recessiva & $9 \mathrm{p} 13.3$ & $G B A 2$ \\
\hline SPG47 & Paraplegia espástica 47 & Autossômica Recessiva & $1 \mathrm{p} 13.2-1 \mathrm{p} 12$ & $A P 4 B 1$ \\
\hline SPG48 & Paraplegia espástica 48 & Autossômica Recessiva & $7 \mathrm{p} 22.1$ & AP5Z1 \\
\hline SPG49 & Paraplegia espástica 49 & Autossômica Recessiva & $14 q 32.31$ & TECPR2 \\
\hline SPG54 & Paraplegia espástica 54 & Autossômica Recessiva & $8 p 11.23$ & DDHD2 \\
\hline SPG55 & Paraplegia espástica 55 & Autossômica Recessiva & $12 \mathrm{q} 24.31$ & C12ORF65 \\
\hline SPG56 & Paraplegia espástica 56 & Autossômica Recessiva & $4 q 25$ & CYP2U1 \\
\hline SPG57 & Paraplegia espástica 57 & Autossômica Recessiva & $3 q 12.2$ & $T F G$ \\
\hline SPG58 & Paraplegia espástica 58 & Autossômica Recessiva & $17 \mathrm{p} 13.2$ & KIFIC \\
\hline SPG59 & Paraplegia espástica 59 & Autossômica Recessiva & $15 \mathrm{q} 21.2$ & USP8 \\
\hline SPG60 & Paraplegia espástica 60 & Autossômica Recessiva & $3 \mathrm{p} 22.2$ & WDR48 \\
\hline SPG61 & Paraplegia espástica 61 & Autossômica Recessiva & $16 \mathrm{p} 12.3$ & ARL6IP1 \\
\hline SPG62 & Paraplegia espástica 62 & Autossômica Recessiva & $10 \mathrm{q} 24.31$ & ERLIN1 \\
\hline SPG63 & Paraplegia espástica 63 & Autossômica Recessiva & $1 \mathrm{p} 13.3$ & $A M P D 2$ \\
\hline SPG64 & Paraplegia espástica 64 & Autossômica Recessiva & $10 \mathrm{q} 24.1$ & ENTPD1 \\
\hline SPG65 & Paraplegia espástica 65 & Autossômica Recessiva & $10 \mathrm{q} 24.3-\mathrm{q} 25.1$ & NT5C2 \\
\hline SPG66 & Paraplegia espástica 66 & Autossômica Recessiva & $5 q 32$ & $A R S I$ \\
\hline SPG67 & Paraplegia espástica 67 & Autossômica Recessiva & $2 \mathrm{q} 33.1$ & $P G A P 1$ \\
\hline SPG68 & Paraplegia espástica 68 & Autossômica Recessiva & $11 \mathrm{q} 13.1$ & FLRT1 \\
\hline SPG69 & Paraplegia espástica 69 & Autossômica Recessiva & $1 \mathrm{q} 41$ & $R A B 3 G A P 2$ \\
\hline SPG70 & Paraplegia espástica 70 & Autossômica Recessiva & $12 \mathrm{q} 13.3$ & $M A R S$ \\
\hline SPG71 & Paraplegia espástica 71 & Autossômica Recessiva & $5 \mathrm{p} 13.3$ & $Z F R$ \\
\hline- & - & Autossômica Recessiva & $9 \mathrm{p} 13.2$ & EXOSC 3 \\
\hline
\end{tabular}

Mais da metade dos casos de HSPs na América do Norte e do norte europeu podem ser atribuídos a defeitos de organelas (Soderblom \& Blackstone, 2006). Em geral, as variantes patogênicas que causam HSP modificam a estrutura do retículo endoplasmático (RE) ou 
interrompem a relação de transporte intracelular de vesículas e macromoléculas do RE com o complexo de Golgi. O RE é composto por uma rede de túbulos de membrana e cisternas que se estendem por todo o citoplasma e encerram no núcleo (Voeltz et al., 2002; Renvoise \& Blackstone, 2010; Friedman \& Voeltz, 2011). Vários fatores contribuem para estrutura do ER, incluindo as proteínas da membrana REEP e proteínas da família reticulon, os reguladores do citoesqueleto de microtúbulos e os componentes da via de secreção da vesícula, que controlam a biogênese e excreção (Voeltz et al., 2006; Audhya et al., 2007; Park et al., 2010; Park \& Blackstone, 2010; Dykstra et al., 2010; Valenzuela et al., 2011; Zanetti et al., 2012).

Dentre as diferentes formas de HSP, estão melhores caracterizados os genes SPAST, ATL1 e REEP1, os quais codificam as proteínas espastina, atlastina GTPase-1, e REEP1, respectivamente; proteínas essas responsáveis pela organização da estrutura do RE, bem como atuam na regulação do transporte intracelular de vesículas e macromoléculas entre o RE e o complexo de Golgi. As variantes patogênicas em SPAST foram as primeiras a serem identificadas e são as mais frequentes em pacientes com HSP não complicada de transmissão AD (Hazan et al., 1999). A proteína espastina se liga aos microtúbulos do citoesqueleto, e dessa forma, atua regulando a morfologia e a estrutura do RE (Park et al., 2010; Connell et al., 2009). Variantes patogênicas no ATL1 também são frequentes em formas de HSP não complicada (Zhao et al., 2001) e a ausência dessa proteína na célula interfere na formação da estrutura do ER e inibe o alongamento axonal nos neurônios corticais de ratos (Zhu et al., 2006; Bian et al., 2011). Variantes patogênicas em REEPl causam HSP não complicada, e esse gene, juntamente com reticulon, é responsável por gerar e manter as curvas das membranas do RE (Zuchner et al., 2006; Friedman \& Voeltz, 2011; Montenegro et al., 2012). Outros estudos demonstraram que a espastatina interage bioquimicamente com proteínas da família da atlastina, REEP e reticulon, sugerindo que essas proteínas estejam fortemente associadas na formação e manutenção do RE 
(Mannan et al., 2006). Além disso, o efeito das variantes patogênicas nos genes que causam HSP sugere que o próprio RE deva desempenhar uma função importante na manutenção do axônio até então ainda pouco conhecida.

Além de defeitos no RE, variantes patogênicas em genes relacionados à função mitocondrial, mielinização, tráfego de vesículas e transporte de membranas também estão relacionados à HSP (Lo Giudice et al., 2014). Defeitos de mitocôndria já estão associados com HSPs desde o final da década de 90. Variantes patogênicas em $S P G 7$, por exemplo, que codifica a proteína paraplegina, podem causar HSP não complicada e complicada em famílias com padrão de herança $\mathrm{AR}$, indicando o possível envolvimento da disfunção da fosforilação oxidativa mitocondrial desencadeando o fenótipo de HSP (Casari et al., 1998). Outro gene com função mitocondrial associado à HSP é o HSPD1, que codifica a proteína chaperonina e está envolvido com o dobramento e montagem de proteínas importadas pela mitocôndria (Hansen et al., 2002). Ademais, acredita-se que SPG20, também associado à HSP, tenha algum envolvimento com atividade mitocondrial (Blackstone et al., 2011). Outro mecanismo importante para o desenvolvimento de HSPs, entre outras doenças neurodegenerativas, é o defeito no transporte axonal neuronal (Stevanin et al., 2008; Dion et al., 2009). Este tema está discutido na seção 1.4 desse capítulo.

\subsection{Transporte axonal}

O transporte axonal é responsável pelo tráfego bidirecional de vesículas (mitocôndrias, lisossomos, vesículas sinápticas entre outras) e macromoléculas (RNA, proteínas, lipídeos, etc.) entre o corpo celular neuronal e sua terminação axonal (Millecamps \& Julien, 2013). Esse transporte, juntamente com outros mecanismos de tráfego neuronal, é de fundamental importância para formação da dinâmica das estruturas pré e pós-sinápticas, e para o 
desenvolvimento e manutenção de processos axonais e dendríticos (Maeder et al., 2014). O transporte axonal tem de ser efetivo, visto que o axônio é uma estrutura delgada e longa, que pode chegar até um metro de comprimento em neurônios motores, e que necessita uma coordenação específica do transporte de carga, em especial das mitocôndrias, para realização funcional do tráfego interno (Lin \& Sheng, 2015).

O transporte axonal é realizado por meio da ligação de proteínas motoras aos microtúbulos. Os microtúbulos do axônio são uniformemente polarizados, o que permite com que proteínas motoras "trafeguem" em apenas um sentido, diferentemente dos microtúbulos localizados na região dendrítica, que são polarizados em ambos os sentidos. O sentido da polarização do microtúbulo é essencial para diferenciar o transporte axonal anterógrado de retrógrado. O transporte anterógrado é definido pelo tráfego de cargas do corpo celular até a terminação axonal e é majoritariamente realizado pelas proteínas da família das cinesinas. O transporte retrógrado se dá no sentido inverso, carregando as cargas presentes na terminação axonal até o corpo celular (Figura 1), sendo as proteínas da família dineína responsáveis por esse transporte (Carter, 2013). Ambas as proteínas motoras (cinesinas e dineínas) hidrolisam ATP para realizar o transporte das vesículas e macromoléculas (Hirokawa et al., 2010). Na Figura 1 estão representadas as estruturas dessas proteínas. 


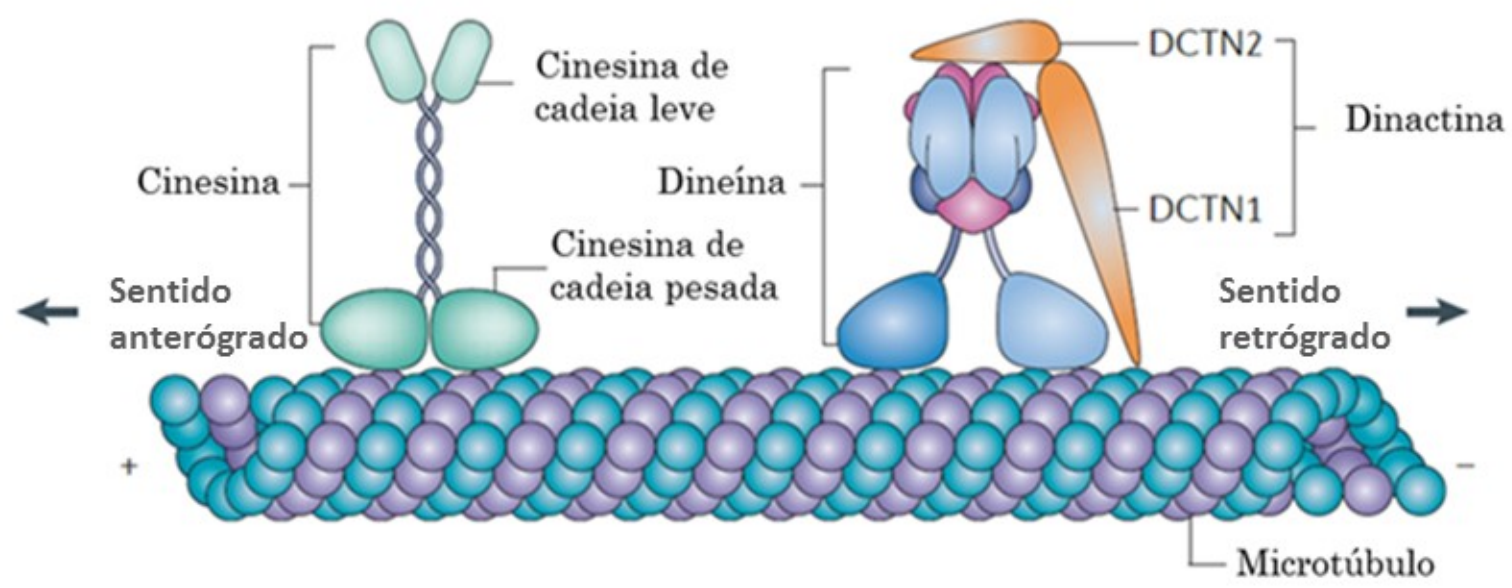

Figura 1. Representação estrutural das cinesinas e dineínas, e o sentido de locomocação dessas proteínas motoras em relação à polarização do microtúbulo. Figura modificada de Millecamps \& Julien (2013).

O reconhecimento específico das vesículas e macromoléculas a serem transportadas através do axônio é feito pela extremidade das proteínas cinesinas e dineínas, com auxílio ou não de proteínas adaptadores. Essas proteínas motoras se ligam em sua região C-terminal a diversos adaptadores, os quais apresentam ligações específicas a um grupo restrito de vesículas e macromoléculas (Millecamps \& Julien, 2013). Várias dessas proteínas adaptadoras são bem estudadas como, por exemplo, as proteínas da família TRAK, MIRO, JNK, entre outras (Fujita et al., 2007; Cho et al., 2007; Lin \& Sheng, 2015). No modelo animal de Drosophila, a proteína adaptadora MIRO foi bem caracterizada por reconhecer o domínio de ligação de cargas das cinesinas (Glater et al., 2006). Em relação aos mamíferos que não possuem a proteína MIRO, foram caracterizados ortólogos desse adaptador, que são as proteínas TRAK1 e TRAK2 (Koutsopoulos et al., 2010; Macaskill et al., 2009), e variantes patogênicas nessas proteínas adaptadoras estão relacionadas direta ou indiretamente com neurodegeneração (ver seção 1.4). 


\subsection{Cinesinas}

As cinesinas são proteínas que atuam como "motores" responsáveis pelo transporte axonal de vesículas e organelas no sentido anterógrado (i.e., do corpo celular para a terminação axonal) por meio de microtúbulos (Pernigo et al., 2013; Birsa et al., 2013). As cinesinas se organizam em heterotetrâmeros e se ligam direta ou indiretamente às cargas que são transportadas ao longo do axônio (Akhmanova \& Hammer, 2010; Baird \& Bennett, 2013). Até o momento 45 genes, pertencentes a 14 superfamílias de cinesinas, já foram descritos (Hirokawa et al., 2009; Verhey \& Hammond, 2009). Dentre o grupo dessa superfamília proteica, a mais estudada é a cinesina-1, comumente chamada de KIF5 e está principalmente relacionada ao transporte axonal anterógrado de mitocôndrias (Hurd \& Saxton, 1996; Pilling et al., 2006; Tanaka et al., 1998). As três proteínas da superfamília KIF5 que atuam na formação do complexo cinesina-1 são KIF5A, KIF5B e KIF5C.

A estrutura proteica das cinesinas de diferentes proteínas da mesma superfamília apresenta alta conservação estrutural. O complexo das cinesinas é formado por duas cinesinas de cadeias pesadas (KHC, do inglês kinesin heavy chain) que se ligam diretamente ao microtúbulo e se movem ao longo do axônio, estando associadas ou não à duas cinesinas de cadeia leve (KLC, do inglês kinesin light chain), cuja função está relacionada à ligação às vesículas e macromoléculas a serem transportadas pelo complexo da cinesina (Bloom et al., 1988; Yip et al., 2016). A porção N-terminal das KHCs é denominada domínio motor ou head e, por meio de hidrólise de ATP, faz a ligação e se move ao longo dos microtúbulos (Figura 2). A estrutura head da cinesina pesada está conectada ao stalk por meio da estrutura neck. O stalk é composto por extensas repetições peptídicas em espiral (do inglês coil) que se dimerizam para formar a estrutura de corpo das cinesinas, sendo o stalk também responsável pelo reconhecimento e ligação às KLCs (Hackney, 2007). Já a subunidade C-terminal das KHCs (tail) está relacionada 
ao reconhecimento e ligação aos adaptadores e cargas (Hirokawa et al., 2010; Diefenbach et al., 1998).

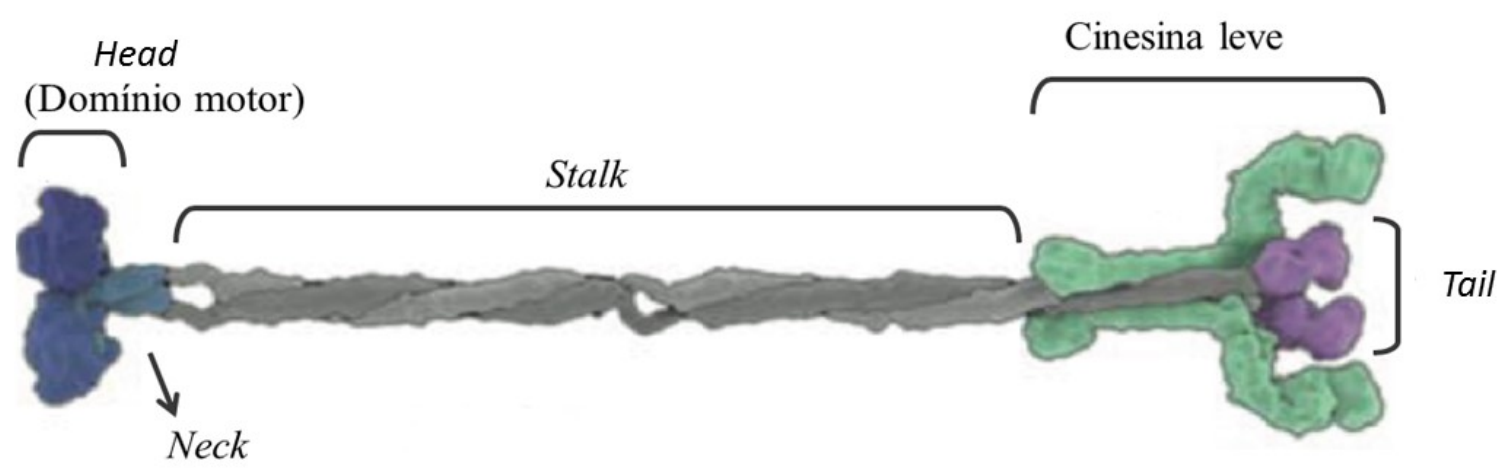

Figura 2. As estruturas denominadas de head, neck, stalk e tail são estruturas representativas das KHCs. As KLCs estão representadas na cor verde. Figura modificada de Carter (2013).

As cinesinas de cadeia leve também são divididas em três domínios: a região N-terminal formada por domínios coiled-coil, compostos por repetições heptapeptídicas que reconhecem a região coiled-coil das KHCs; a região de domínio repetitivo de tetratricopeptídeos (TRPs) e a região C-terminal (Figura 3). As duas últimas regiões citadas são as mais bem estudadas e têm como função realizar a ligação das cinesinas às mais diversas cargas (Kamal \& Goldstein, 2002; Zhu et al., 2012). Os domínios TRP são chamados de módulos de interação proteína-proteína, no qual consistem em repetições de 34 aminoácidos e são os domínios-chave para reconhecimento de cargas específicas (D’Andrea \& Regan, 2003). Esses domínios apresentam diversidade estrutural dentro o grupo das KLCs. 


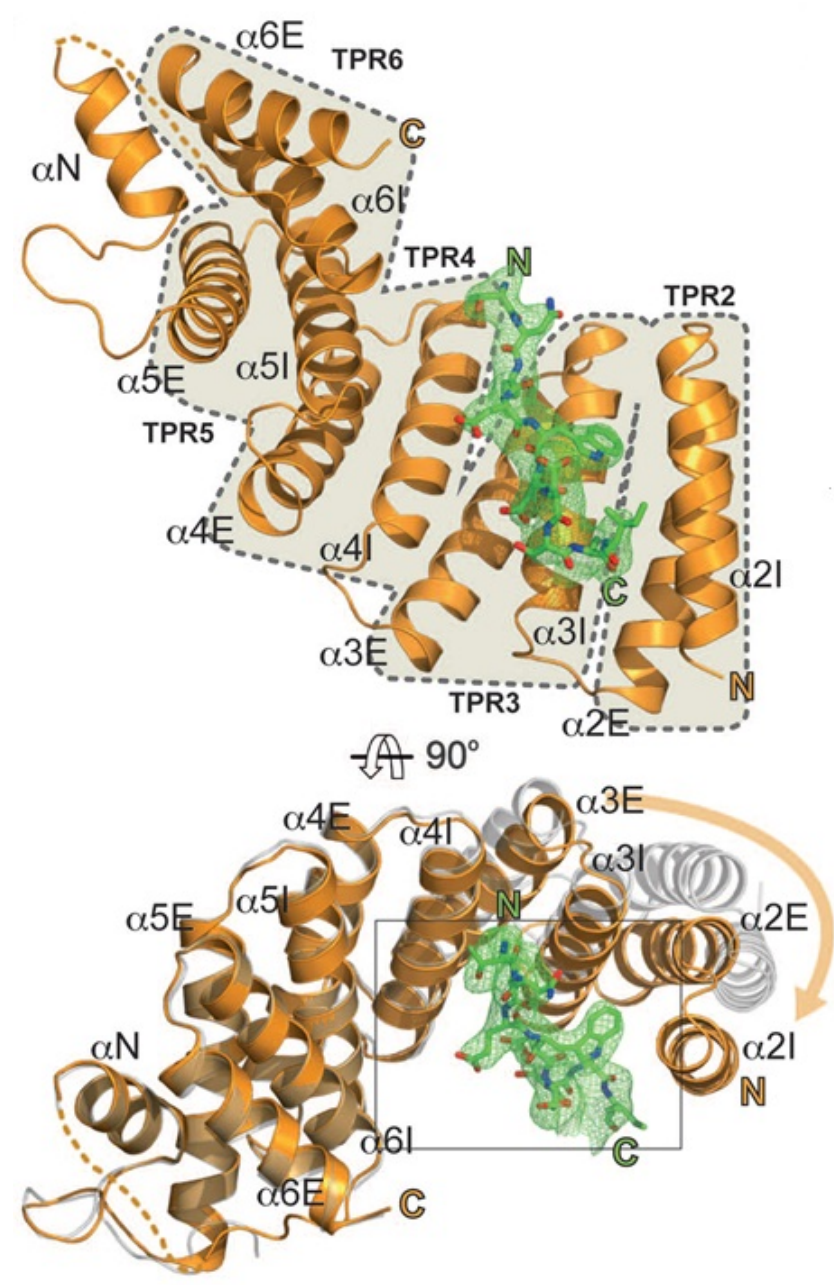

Figura 3. A região tetratricopeptídeo (TRP) coiled-coil, que tem como função o reconhecimento de cargas específicas a serem transportadas pela cinesina. A região TRP está delimitada dentro da linha tracejada sombreada em cinza (Zhu et al., 2012).

Quatro proteínas da família das cinesinas de cadeia leve foram descritas até o momento e são codificadas por quatro diferentes genes $(K L C 1, K L C 2, K L C 3$ e $K L C 4)$, sendo as proteínas KLC1 e KLC2 as mais estudadas e apresentam $67 \%$ de identidade proteica entre si (Morihara et al., 2014). O $K L C 1$, bem como o $K L C 2$, apresenta alta expressão em tecido cerebral e em neurônios, e as proteínas codificadas por esses genes se ligam à diversas proteínas adaptadoras e à cargas neuronais (McGuire et al., 2006; Kamm et al., 2004; Bracale et al., 2007; Kimura et al., 
2005; Lalioti et al., 2009; Araki et al., 2007; Konecna et al., 2006). Muitas proteínas adptadoras e várias cargas são reconhecidas por ambas as cinesinas KLC1 e KLC2, porém algumas são reconhecidas apenas pela região TRP de uma das duas cinesinas de cadeia leve, tornando essencial o funcionamento de ambas em tecidos e tempos diferentes (Zhu et al., 2012). Sabe-se também que o KLC2 tem papel importante na ligação física e tráfego de mitocôndrias e da enzima Na,K-ATPase (Trejo et al., 2010).

A cinesina de cadeia leve-2 se liga fisicamente com as cinesinas de cadeia pesada KIF5A e KIF5B (Morton et al., 2010). O KLC2, localizado na região cromossômica 11q13.2 (chr11:66025174-66035332), apresenta 14 transcritos e duas isoformas proteicas conhecidas com 622 (CCDS8130) e 545 (CCDS44653) resíduos de aminoácidos. O maior transcrito tem aproximadamente $3-\mathrm{Kb}$ e possui 16 éxons, sendo o primeiro deles não codificador. $\mathrm{O} K L C 2$ expressa-se principalmente em tecido nervoso central e periférico (Cabeza-Arvelaiz et al., 1993; Rahman et al. 1998). Até o presente momento, variantes patogênicas em $K L C 2$ não haviam sido associadas a qualquer doença genética.

\subsection{Doenças neurodegenerativas associadas ao defeito de transporte axonal}

Defeitos relacionados à formação e manutenção dos microtúbulos geralmente são deletérios e acarretam a morte neuronal (Rahman et al., 1999; Mandelkow \& Mandelkow, 2002). Defeitos de transporte axonal, principalmente o defeito de transporte de mitocôndrias, também estão relacionados a diversos casos de doenças neurodegenerativas e de distúrbios neurológicos (Sheng \& Cai, 2012; Gindhart et al., 1998; Rahman et al., 1999; Mandelkow \& Mandelkow, 2002; Stokin et al., 2005; Perlson et al., 2010; Millecamps \& Julien, 2013). Tanto as proteínas motoras como as adaptadoras envolvidas no transporte axonal podem causar, quando mutadas, neurodegeneração. Alterações estruturais ou que levem a diminuição da expressão das proteínas 
adaptadoras MIRO e TRAK causam deficiência no transporte anterógrado de mitocôndrias (Stowers et al., 2002; van Spronsen et al., 2013; Brickley \& Stephenson, 2011). Variantes patogênicas em genes da família da dineína (Lipka et al., 2013) e das cinesinas de cadeia pesada $(K I F 2 A, K I F 1 B, K I F 5 C$ e KIF21A) já foram associadas a várias doenças neurodegenerativas (revisão em Maday et al., 2014). Entre as cinesinas de cadeia leve, KLC1 é mais investigada e foi a primeira a ser associada à neurodegeneração, tal como há sugestões da importância dessa cinesina na doença de Alzheimer (Morihara et al., 2014), e ela apresenta 67\% de identidade a nível proteico com KLC2.

Dentro do espectro das paraplegias espásticas hereditárias, variantes patogênicas em três cinesinas de cadeia pesada (KIF5A, KIF 1A e KIF1C) foram associadas à HPS (Reid et al., 2002; Ebbing et al., 2008; Novarino et al., 2014; Caballero Oteyza et al., 2014). Variantes patogênicas em $K I F 5 A$, que codifica a proteína cinesina de cadeia pesada da isoforma 5A, por exemplo, causam diminuição da afinidade e velocidade de transporte de macromoléculas através do axônio, resultando na HSP conhecida como SPG10 (Ebbing et al., 2008). Recentemente foi descrita uma família com HSP apresentando uma variante patogênica em homozigose na cinesina de cadeia leve-4 codificada por KLC4 (Bayrakli et al., 2015), evidenciando que a perda de função das cinesinas, tanto da cadeia pesada quanto da leve, tem papel fundamental no distúrbio do transporte axonal, causando neurodegeneração e levando ao fenótipo de paraplegia espástica hereditária.

\subsection{Modelos animais de neurodegeneração}

Diversos modelos animais mostraram que defeito de transporte axonal causa neurodegeneração. Várias espécies de animais, desde Drosophila melonogaster até murinos como Mus Musculus e Rattus Novergicus já foram usados como modelo para doenças 
neurodegenerativas humanas (Munch et al., 2005; Falzone et al., 2009; Hirokawa et al, 2010). O modelo animal de zebrafish (Danio rerio) tem sido utilizado com bastante frequência em estudos genéticos, uma vez que seu genoma, ainda que parcialmente duplicado, apresenta vários genes em cópia única. Além disso, esse modelo animal apresenta um curto período de desenvolvimento embrionário, facilitando a geração de animais knockdown ou transgênicos. Estudos funcionais por meio de knockdown realizados em genes de zebrafish, no qual os genes ortólogos em humanos foram previamente associados à HSP, demonstraram que a perda de função desses genes apresentaram fenótipo sugestivo de neurodegeneração no embrião (Tabela 2). Em resumo, vários estudos demonstraram que a perda de função de genes associados a HSPs, geralmente realizada por knockdown em zebrafish utilizando morfolinos, causa fenótipo de cauda-curvada, déficit de nado do embrião, letalidade e defeitos no eixo corporal no peixe.

Tabela 2. Ortólogos de zebrafish associados à HSPs em Homo sapiens.

\begin{tabular}{|c|c|c|c|}
\hline Locus & $\begin{array}{c}\text { Gene } \\
\text { (Homo sapiens) }\end{array}$ & $\begin{array}{c}\text { Gene ortólogo } \\
\text { (Danio rerio) }\end{array}$ & Referência \\
\hline SPG3A & ATL1 & atll & Fassier et al., 2010 \\
\hline SPG4 & $S P A S T$ & spast & Butler et al., 2010 \\
\hline SPG8 & KIAA0196 & strumpellin & Valdmanis et al., 2007; Clemen et al., 2010 \\
\hline SPG11 & SPG11 & $\operatorname{spg} 11$ & Southgate et al., 2010; Martin et al., 2012 \\
\hline SPG15 & ZFYVE26 & zfyve 26 & Martin et al., 2012 \\
\hline SPG39 & PNPLA6 & pnpla6 & Song et al., 2013 \\
\hline SPG42 & SLC33A1 & slc33al & Lin et al., 2008 \\
\hline SPG46 & $G B A 2$ & $g b a 2$ & Martin et al., 2013 \\
\hline SPG59 & USP8 & usp 8 & Novarino et al., 2014 \\
\hline SPG61 & ARL6IP1 & arloip 1 & Novarino et al., 2014 \\
\hline SPG67 & $P G A P 1$ & pgapl & Novarino et al., 2014 \\
\hline SPG70 & MARS & Mars & Novarino et al., 2014 \\
\hline
\end{tabular}

Apesar do zebrafish ser bastante usado como modelo animal de doenças humanas, o modelo murino é uma excelente alternativa para geração de linhagens estáveis de diversas doenças neurodegenerativas devido sua maior semelhança genética com o Homo sapiens. A 
esclerose lateral amiotrófica (ELA) e a distrofia muscular de Duchenne, por exemplo, apresentam diversos modelos de ratos e camundongos transgênicos gerados (Collard et al., 1995; revisão em Vainzof et al. 2008; revisão em Philips \& Rothstein, 2015). Camundongos trangênicos vem sendo utilizados como modelo de doenças neurodegenerativas desde a década de 80 quando o grupo de Bulfield et al. (1984) desenvolveu o primeiro modelo de distrofia de Duchenne. Esse animal apresentava elevados níveis de creatina quinase em tecido muscular e de piruvato quinase no soro, além de apresentarem lesões histológicas características de distrofia muscular. Após esse primeiro modelo murino, dezenas de camundongos transgênicos modelados para doenças neurodegenerativas foram gerados (Vainzof et al., 2012). Em geral, os camundongos transgênicos para doenças neurodegenerativas apresentam como características clínicas a distrofia esquelética de leve a grave, cardiopatia e fraqueza muscular. Testes físicos, testes comportamentais e avaliação da longevidade são os melhores experimentos e critérios utilizados como indicadores para diagnosticar e acompanhar a perda ou progressão da disfunção neuromuscular.

Doenças neurodegenerativas relacionadas ao defeito de transporte axonal já foram estudadas por meio de modelos murinos transgênicos para os genes mutados nessas doenças. Camundongos apresentando variantes patogênicas em genes relacionados ao tráfego neuronal apresentam características bem definidas de neurodegeneração nesse modelo animal (revisão em Roy et al., 2005). Em relação aos modelos animais envolvendo cinesinas, o modelo knockdown do Klc1 em camundongo (Klc1 $\left.1^{\mathrm{tm} 1 \mathrm{Gsn}} / \mathrm{Klc} 1^{\mathrm{tm} 1 \mathrm{Gsn}}\right)$ apresentou fenótipo de neurodegeneração, sendo os principais achados a morfologia anormal axonal, defeito de transporte axonal, defeito morfológico da matéria branca cerebral e da medula espinhal, degeneração axonal e depósito de proteínas tau (Rahman et al., 1999). De acordo com o banco de dados Mouse Genome Database (MGD; http://www.informatics.jax.org/), camundongos knockdown do Klc2 
$\left(\mathrm{Klc}^{\mathrm{tmle(EUCOMM)Wtsi}} / \mathrm{Klc} 2^{\text {tmle(EUCOMM)Wtsi }}\right)$ apresentaram alterações de comportamento, tais como hiperatividade e de respostas neurológicas, como ausência do reflexo auditivo, além de outros defeitos relacionados à audição e de homeostasia e metabolismo (Eppig et al., 2015). Outro banco de dados relacionado à fenótipos em camundongos (https://www.mousephenotype.org/) mostrou que animais knockdown do Klc2 apresentam principalmente defeitos auditivos, além de defeitos secundários não significativos (que não aparecerem em replicatas biológicas): defeitos neurológicos, de crescimento, da estruturação esquelética, visuais entre outros.

\subsection{Síndrome SPOAN}

A síndrome SPOAN (OMIM \#609541), acrônimo do inglês spastic paraplegia, optic atrophy and neuropathy, é uma doença neurodegenerativa de herança AR que tem como achados clínicos a atrofia ótica congênita e aparentemente não progressiva; a paraparesia espástica de início na primeira década de vida, levando à perda da deambulação autônoma antes da adolescência; a neuropatia periférica, com início clínico após a primeira década de vida e causando perda progressiva da função dos membros superiores, o que leva a comprometimento da sensibilidade profunda e do agravamento da fraqueza muscular; as deformidades articulares e da coluna; a resposta de sobressalto a sons inesperados e ausência de comprometimento cognitivo e auditivo (Macedo-Souza et al., 2005; Macedo-Souza et al., 2009). Em estudo clínico e fisiológico mais detalhado sobre essa síndrome, Amorim et al. (2014) avaliou 27 pacientes com a síndrome SPOAN e os principais achados clínicos desse estudo foram fraqueza distal e atrofia muscular, deformidade nos pés e na coluna, e ausência de reflexos no tornozelo de todos os pacientes.

A síndrome SPOAN foi identificada pela primeira vez em um município do interior do estado do Rio Grande do Norte, Serrinha dos Pintos, com população de 4.538 habitantes (IBGE, 
2010). Em estudo realizado por Santos et al. (2010) foi averiguado que 32,5\% das uniões encontradas nesse município ocorrem entre pessoas aparentadas. Nesse município foram identificadas 18 pessoas afetadas pela síndrome SPOAN (Macedo-Souza et al., 2005). Estima-se que um em cada 250 habitantes de Serrinha dos Pintos seja afetado por essa síndrome e que 11\% dos habitantes desse município sejam heterozigotos para a variante patogênica da síndrome SPOAN (Macedo-Souza et al., 2009).

No total foram diagnosticados 75 com a síndrome SPOAN por meio de avaliação clínica e com genótipo confirmado para a variante patogênica. A maioria dos indivíduos afetados é oriunda da região do interior do Rio Grande do Norte, Nordeste brasileiro (Figura 4). Além dos pacientes brasileiros, dois irmãos egípcios (filhos de pais consanguíneos) foram classificados com essa síndrome devido à presença em homozigose da variante patogênica causadora da síndrome SPOAN e por apresentarem o mesmo diagnóstico clínico dos pacientes brasileiros.

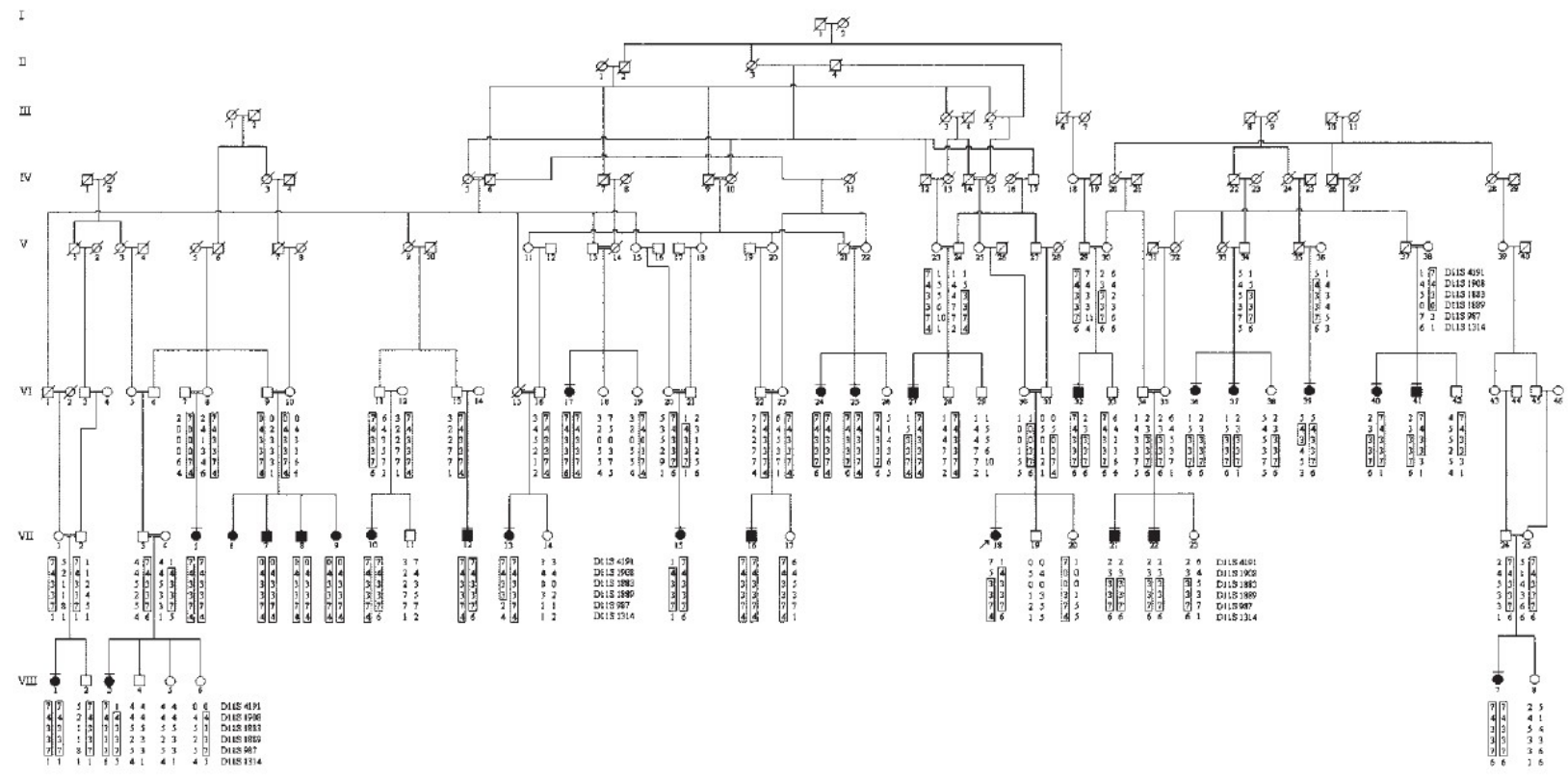

Figura 4. Genealogia de um grande núcleo familiar da síndrome SPOAN do estado do Rio Grande do Norte. Nota-se vários pacientes com essa síndrome e a relação endogâmica dos pais dos pacientes. Figura obtida em Macedo-Souza et al. (2005). 
Até a realização dos experimentos desta tese de doutorado, era conhecido apenas a região cromossômica (11q13) onde estava mapeada a variante patogênica causativa da síndrome SPOAN, identificada por meio de estudo de ligação utilizando marcadores moleculares do tipo microssatélites. A primeira região mapeada possuía 4.8-Mb de comprimento, com o valor de LOD score de 14,43, localizada próxima ao marcador D11S1883 (Macedo-Souza et al., 2005). Essa região mapeada foi posteriormente reduzida a 2.3-Mb com a adição de amostras de mais pacientes à casuística (Macedo-Souza et al., 2009). Com base na análise da região cromossômica mapeada, os três melhores genes candidatos (expressos em tecido cerebral) foram selecionados para sequenciamento de Sanger dos éxons codificadores: $L R F N 4$, que codifica uma glicoproteína que tem função no desenvolvimento do sistema nervoso central; $K L C 2$, que codifica a proteína cinesina de cadeia leve-2, cuja função está relacionada ao transporte axonal de vesículas e macromoléculas; e CCS, que codifica uma proteína chaperona que é responsável pela manutenção do cobre intracelular. Entretanto, nenhuma variante patogênica foi encontrada em homozigose nos éxons codificadores de aminoácidos desses genes nos pacientes (Macedo-Souza et al., 2009).

Essa tese de doutorado teve como intenção continuar o estudo genético de identificação da variante patogênica associada à síndrome SPOAN e a realização de estudos funcionais utilizando os modelos in vitro e in vivo para responder as questões relacionadas à patogenicidade da variante e compreender os mecanismos patofisiológicos dessa síndrome. Estudo de segregação de variantes candidatas, análise de expressão do gene candidato por meio de qRT-PCR, ensaios de knockdown e superexpressão do gene associado à síndrome em modelo de zebrafish, e a geração de camundongos transgênicos como modelo animal da síndrome SPOAN foram executados durante o período de doutoramento e estão descritos nesta tese. 


\subsection{Objetivo}

O objetivo deste trabalho identificar a variante patogênica e o gene associados à síndrome SPOAN e buscar subsídios da variante patogênica como causadora da síndrome por meio de estudos in vitro e in vivo.

\subsubsection{Objetivos específicos}

- Identificar a variante patogênica causadora da síndrome SPOAN.

- Realizar experimentos in vitro para avaliar a expressão do gene alterado nos pacientes com a síndrome SPOAN em comparação com controles saudáveis.

- Realizar experimentos in vivo de knockdown e superexpressão do gene alterado em modelo de zebrafish.

- Gerar linhagens estáveis de camundongos transgênicos como modelo animal da síndrome SPOAN. 


\section{Materiais e métodos}

\subsection{Casuística}

A casuística deste estudo foi composta por 75 pacientes diagnosticados clínica e geneticamente com a síndrome SPOAN. Esses pacientes são oriundos ou tem ancestrais provenientes do interior do estado do Rio Grande do Norte e estados circunvizinhos $(\mathrm{n}=70)$. Outros pacientes originários dos estados de Minas Gerais $(n=1)$ e Rio Grande do Sul $(n=2)$, sem relação de parentesco com as famílias do Nordeste também foram diagnosticados com a síndrome SPOAN e foram incluídos nesse estudo. Além da casuística brasileira, foram investigadas amostras de dois irmãos com fenótipo dessa síndrome provenientes do Egito, por meio de colaboração com o grupo coordenado por Joseph Gleeson, MD, Ph.D., do laboratório de neurogenética da University of California, San Diego. Todos os pacientes, além de controles normais familiares, tiveram amostras de sangue coletadas para extração de DNA.

Para realização de ensaios sobre expressão gênica, foram coletadas amostras de sangue de pacientes com a síndrome SPOAN $(n=7)$, de heterozigotos para a variante patogênica $(n=7)$ e homozigotos wild-type familiares $(n=6)$ para extração de RNA. Amostras de fibroblastos de pele também foram coletadas para extração de RNA de pacientes $(n=5)$, de heterozigoto para a variante patogênica da síndrome SPOAN $(n=1)$ e de controles saudáveis normais $(n=4)$. Fibroblastos de pacientes e controles foram diferenciados em neurônios motores (NM) pela Dr. Lúcia Inês Macedo-Souza, segundo protocolo descrito em Melo et al. (2015). Esse projeto foi aprovado pelo comitê de ética em pesquisa em seres humanos do Instituto de Biociências da Universidade de São Paulo (Protocolo CEP 010/2003). 
2.2. Estudo molecular realizado no laboratório de doenças neuromusculares do Instituto de Biociências da Universidade de São Paulo

\subsubsection{Sequenciamento de nova geração e estudos de segregação das variantes}

Como parte desse estudo, duas amostras de pacientes com a síndrome SPOAN, sendo um de origem brasileira e outro de origem egípcia, foram submetidas ao sequenciamento de nova geração do exoma (WES, do inglês whole-exome sequencing) usando o kit da Agilent SureSelect Human All Exon 50Mb e foi sequenciado no Illumina HiSeq2000 (Illumina, San Diego, CA, EUA). A amostra do paciente brasileiro foi sequenciada nas dependências do laboratório Broad Institute of MIT and Harvard, enquanto que a amostra do paciente egípcio foi sequenciada no laboratório da Howard Hughes Medical Institute.

A análise de bioinformática foi realizada pelo Dr. João Kitajima da Mendelics (São Paulo, SP), o qual efetuou o alinhamento das sequências usando a montagem do genoma GRCh37 por meio do software BWA (Li \& Durbin, 2010). A genotipagem foi realizada usando o GATK (McKenna et al., 2010), SNPs e InDels foram anotados usando o ANNOVAR (Wang et al., 2010) e a detecção de CNVs foi avaliada usando o pacote em R do ExomeDepth (Plagnol et al., 2012). A cobertura média do exoma na região de ligação foi de 40x na amostra brasileira e $77 x$ na amostra egípcia. As variantes detectadas no exoma dos dois pacientes foram filtradas por frequência menor que 1\% usando os bancos do 1000 genomas (http://www.1000genomes.org/), NHLBI GO Exome Sequencing Project (ESP, http://evs.gs.washington.edu/EVS/), Exome Aggregation Consortium (ExAC, http://exac.broadinstitute.org/), e do banco interno da Mendelics com 1484 amostras brasileiras. As variantes candidatas foram sequenciadas pelo método de Sanger para checar a segregação com o fenótipo, e essa etapa do estudo de cosegregação das variantes foi realizada pela Dra. Lúcia Inês Macedo-Souza (Relatório FAPESP, 2012). 
Após a realização do experimento para checar a segregação com o fenótipo das variantes detectadas no WES, nenhuma variante apontou como forte candidata a explicar o fenótipo. Dessa forma decidimos submeter uma amostra de outro paciente brasileiro para o sequênciamento do genoma completo (WGS, do inglês whole-genome sequencing) utilizando o kit Illumina TruSeq DNA. A análise de bioinfórmatica também foi realizada pelo Dr. João Kitajima, utilizando o mesmo pipeline descrito acima no WES. A cobertura do WGS na região de ligação da síndrome SPOAN foi de 26x. As variantes detectadas nesse experimento foram filtradas usando os mesmos parâmetros e bancos de dados citados acima, e após a filtragem, a deleção de 216-pb localizada na região upstream do KLC2 (chr11.hg19:g.66,024,557_66,024,773del) foi detectada em homozigose no paciente com a síndrome SPOAN. Essa variante foi genotipada para checar a cosegregação usando os primers forward: 5'-GCCCTGGGTTCATTGACTTA-3' e reverse: 5'ACCCAGACGGACAAGCTAGA-3' por meio da técnica de amplificação do DNA por PCR seguida de eletroforese em gel de agarose. Essa variante também foi checada em controles familiares $(n=111)$ e controles normais não-aparentados brasileiros $(n=474)$.

\subsubsection{Extração de RNA e PCR em tempo real (qRT-PCR)}

A extração de RNA de fibroblastos de pacientes $(n=5)$, heterozigoto $(n=1)$ e controles normais $(n=4)$, bem como a extração de RNA de NM derivados de iPSC dos mesmos indivíduos foi realizada utilizando TRIZOL (Invitrogen) e o kit da Norgen Biotek RNA/DNA/Protein Purification (Norgen Biotek Corp., Ontário, Canadá). A extração de RNA de sangue total de pacientes $(n=7)$, heterozigotos $(n=7)$ e controles familiares wild-type $(n=6)$ foi realizada utilizando o kit PAXgene Blood RNA (Qiagen). O RNA extraído de todas as amostras foi submetido à eletroforese em gel de agarose para verificar a integridade do material. O RNA 
extraído dos três tipos celulares foi retrotranscrito utilizando primers de oligo(dT) com o kit SuperScript ${ }^{\mathrm{TM}}$ III First-strand Synthesis System (Life Technologies).

Os estudos de PCR em tempo real (qRT-PCR) foram realizados utilizando cDNA de fibroblastos, de NM derivados de iPSC e de sangue, de pacientes e controles. Os primers para o qRT-PCR foram desenhados entre a junção éxon 3-4 do $K L C 2$, a fim de amplificar todas os transcritos desse gene. A sequência dos primers foram: forward: 5'GACGTCCCCAAAGACACACT-3'; reverse: 5'-CATGCTGACCAGACACATCC-3'. A reação de qRT-PCR foi normalizada para os genes endógenos $G A P D H$ e $T B P$ utilizando o aparelho LightCycler® 480 (Roche). A expressão relativa do $K L C 2$ foi calculada utilizando o método do $2^{-\Delta \Delta \mathrm{CT}}$ (Schmittgen \& Livak, 2008).

\subsection{Colaboração com outros centros de pesquisa}

O estudo funcional utilizando o modelo animal do zebrafish foi realizado em colaboração com o grupo coordenado pela Profa. Dra. Nora Beatriz Calcaterra, do Instituto de Biologia Molecular e Celular da Universidade de Rosário, Argentina. Esse laboratório é especializado no uso desse animal como modelo de doenças genéticas humanas relacionadas ao desenvolvimento embrionário. Experimentos de knockdown, superexperssão e de localização do klc2 em zebrafish foram realizados nas dependências desse laboratório na Argentina durante o período de Março a Junho de 2014.

O estudo funcional utilizando o modelo de camundongo foi realizado durante o período do "doutorado-sanduíche", entre Março a Dezembro de 2015, em colaboração com o grupo de pesquisa do laboratório Mammalian Functional Genomics Laboratory coordenado por Len Pennacchio, Ph.D., do Lawrence Berkeley National Laboratory, em Berkeley, Estados Unidos. $\mathrm{Na}$ tentativa de compreender o mecanismo patofisiológico e molecular da síndrome SPOAN, 
foram realizados experimentos de gene reporter e geração de camundongo transgênico para o KLC2 humano nas dependências desse laboratório.

\subsection{Modelo animal de zebrafish}

O modelo animal selecionado para estudo in vivo da função do gene klc2 relacionado à síndrome SPOAN foi o zebrafish (Danio rerio), devido seu curto período de desenvolvimento embrionário e esse modelo possui a proteína ortóloga com $79 \%$ de similaridade proteica em relação à humana (Altschul et al., 1997). Além disso, esse gene está em apenas uma cópia no genoma do Danio rerio (ZFIN ID: ZDBGENE-030131-2670), tornando factível a utilização do desse modelo animal nesse estudo e ensaios de knockdown e de hibridação in situ desse gene em zebrafish não haviam sido realizados até o presente estudo. Nós realizamos também a técnica de WISH (whole-mount in situ hybridization) para identificar os locais de expressão do klc2 em diferentes fases do desenvolvimento embrionário do zebrafish, utilizando o protocolo descrito em Weiner et al. (2012).

Embriões adultos de zebrafish foram mantidos a $28^{\circ} \mathrm{C}$ durante $14 \mathrm{~h}$ expostos à luz e $10 \mathrm{~h}$ no escuro, seguindo protocolo estabelecido pelo laboratório supervisionado pela Dra. Nora Calcaterra. Os embriões utilizado nos experimentos foram obtidos por fecundação natural. Os ensaios usando Danio rerio nesse estudo foram aprovados pelo comitê de ética em experimento animal do departamento de ciências farmacológicas e bioquímicas da Universidade Nacional de Rosário, Argentina (Protocolo No. 429/2014).

\subsubsection{Extração de RNA de zebrafish e cDNA}

Embriões em diferentes estágios embrionários (6, 24, 48 e 72-hours post fertilization; hpf) foram selecionados para esse estudo. Para extração do RNA foi utilizado o reagente TRIZOL® (Invitrogen) e as amostras de RNA dos quatro estágios embrionários selecionados foram 
misturadas e armazenadas a $-70^{\circ} \mathrm{C}$. A reação de transcrição reversa foi realizada pela enzima SuperScript Reverse Transcriptase (Invitrogen), usando o primer 5'CAACAGCACTTTCCCCACG-3', que hibrida na região 3'UTR desse gene. Esse mesmo cDNA foi utilizado para todas as outras etapas do estudo funcional em zebrafish.

\subsubsection{Clonagem dos cDNAs do $k l c 2$ em plasmídeos}

O plasmídeo pCS2+MT+eGFP foi utilizado para inserção completa do cDNA de aproximadamente 2-kb do $k l c 2$ com a finalidade de gerar clones de mRNA desse gene. Esse plasmídeo apresenta um polylinker fusionado ao cDNA de eGFP entre os sítios EcoRI e XhoI e a descrição da sequência do plasmídio está descrita na Figura 5. Os primers desse estudo foram desenhados para a amplificação do cDNA com a sequência das enzimas de restrição EcoRI e SacI, e estão descritos na Tabela 3. Foram adicionados nucleotídeos (um ou dois) às sequências dos primers para manter a matriz de leitura (ORF). O cDNA amplificado foi submetido à eletroforese em gel de agarose, sendo as bandas de aproximadamente 2-kb recortadas e purificadas. Os produtos (cDNA amplificado e Plasmídeo) foram digeridos com EcoRI e SacI a $37^{\circ}$ overnight. Posteriormente foi efetuada a ligação do cDNA ao plasmídeo e foram utilizadas bactérias E. coli competentes para fazer a transformação. O cDNA das colônias que se desenvolveram foram checadas por meio do sequenciamento de Sanger para verificar se continham o inserto e a direção ao qual o inserto foi incluído no vetor. 


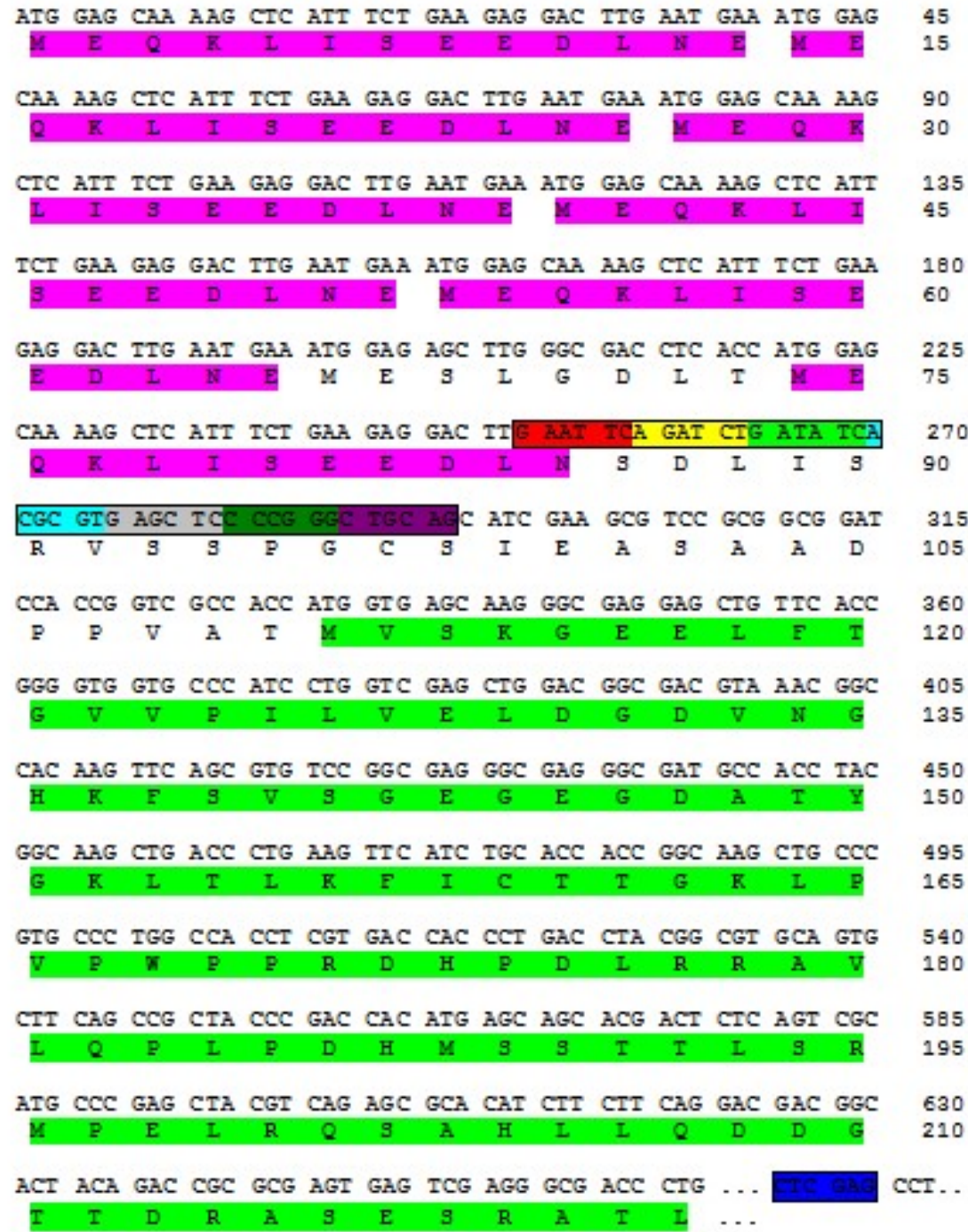

Figura 5. Sequência do plasmídeo pCS2+MT com o cDNA do eGFP fusionado. Na cor rosa estão os epítopos marcados do Myc; em vermelho EcoRI; em amarelo BglII; em verde e com contorno EcoRV; em anil MluI; Em cinza SacI; em verde escuro SmaI; em roxo PstI; em verde e sem contorno eGFP; e em azul escuro XhoI. 
Tabela 3. Sequência dos primers utilizados para a amplificação do cDNA do $k l c 2$. Em destaque vermelho e negrito estão as sequências para amplificação dos sítios de restrição da EcoRI e SacI. Foram adicionados nucleotídeos na região 5' dos primers para certificar a ligação da enzima de restrição com a sequência. Também foram adicionados nucleotídeos após a sequência dos sítios de restrição para manter a matriz de leitura.

\begin{tabular}{ll}
\hline Primers & Sequência 5'-3' \\
\hline Forward & GGGGAATTCAATGTCCACCATGGTTTACCCTC \\
Reverse & CCCGAGCTCACACTGATCAGAGAGTTGCGTCT \\
\hline
\end{tabular}

O plasmídeo pGEM-T Easy Vector System (Promega) foi utilizado para inserção das sondas do cDNA do klc2 para realização do experimento de WISH. As sondas foram amplificadas utilizando os primers: forward: 5'-TGGGCGCAGATGATCCAAAT-3'; e reverse: 5'-CAACAGCACTTTCCCCACG-3'. O cDNA amplificado foi submetido a eletroforese em gel de agarose, sendo as bandas de aproximadamente 830-pb recortadas e purificadas. Após a inserção das sondas no plasmídeo pGEM-T Easy, colônias com E. coli competentes foram utilizadas para a transformação. Foi utilizado o antibiótico ampicilina para seleção de colônias com o inserto e foi adicionado X-gal como controle negativo. O cDNA obtido das colônias foi checado por meio de PCR utilizando os mesmos primers usados para amplificar as sondas e o cDNA das colônias que foram sequenciados para verificar o sentido do inserção.

\subsubsection{Estudo de knockdown do klc2 em zebrafish}

A técnica de knockdown foi executada por meio de microinjeções de morfolinos no saco vitelino de embriões de zebrafish no estágio de uma a quatro células, nas concentrações de 4 e 6ng. A sequência do morfolino de bloqueio de tradução $\left(\mathrm{MO}^{k l c 2-\mathrm{TB}}\right)$ foi 5'GGTGGACATCACCCACTGACACACA-3'(o controle mismatch [misMO $\left.{ }^{k l c 2-\mathrm{TB}}\right]$ foi 5'- 
GGaGcACATgACCCAgTcACACACA-3') e a sequência do morfolino de bloqueio de splicing $\left(\mathrm{MO}^{k l c 2-\mathrm{SP}}\right)$ foi 5'-CGTGTGTGTTTCACCTGTGCTTCCC-3' $^{\prime} \quad\left(\operatorname{misMO}^{k l c 2-\mathrm{SP}}\right.$ foi ${ }^{\prime}$ 'CGTcTcTGTTTgACCTcTcCTTCCC-3').

\subsubsection{Superexpressão do klc2 e resgate de fenótipo em zebrafish}

A técnica de superexpressão do klc2 em zebrafish foi realizada por meio de microinjeções do mRNA (mRNA ${ }^{k l c 2-e G F P}$ ) no saco vitelino de embriões no estágio de uma a quatro células, nas concentrações de 100, 150 e 200pg. As mesmas concentrações foram microinjetadas utilizando o $\mathrm{mRNA}^{\text {eGFP }}$ como controle. Os embriões fluorescentes foram selecionados no estágio de 24-hpf para imagem e caracterização do fenótipo. O resgate de fenótipo foi realizado por meio de coinjeção de 6 ng de $\mathrm{MO}^{\text {klc2-SP }}$ com 100pg de mRNA ${ }^{\text {klc2-eGFP }}$ no saco vitelino de embriões no estágio de uma a quatro células.

\subsubsection{Whole-mount in situ hybridization (WISH)}

A técnica de WISH foi utilizada para identificar os locais de expressão do klc2 em diferentes estágios do desenvolvimento embrionário do zebrafish (4- a 8-células, 15 a 20 somitos, 48- e 72-hpf), e foi realizado de acordo com protocolo descrito em Thisse \& Thisse (2008). O mRNA antisenso foi sintetizado in vitro usando como molde o cDNA full-lenght do klc2 que foi clonado no plasmídeo pCS2+MT+eGFP, sendo marcado com digoxigenina uridina-5'- trifosfato (Digoxigenina-11-UTP). Após a hibridação, a localização das sondas marcadas foi visualizada imunoquimicamente usando o anticorpo anti-digoxigenina. Essas sondas foram hibridadas em embriões fixados overnight a 4\% em paraformaldeído. No estágio final, os embriões foram visualizados e registrados utilizando os equipamentos MVX10 Olympus Microscope e 
MVXTV1XC Olympus digital câmera, disponíveis no laboratório de ciências moleculares da Universidade de Rosário, Argentina.

\subsection{Metodologia do uso do modelo animal de camundongo}

O modelo murino selecionado para gerar linhagens transgênicas do KLC2 humano foi o camundongo (Mus musculus) da linhagem FVB, visto que várias estudos usam esse modelo animal para mimetizar o fenótipo de doenças neurodegenerativas. Devido a síndrome SPOAN ser acarretada pela superexpressão do $K L C 2$, nesse presente estudo geramos camundongos que superexpressam o $K L C 2$ humano para avaliar o fenótipo do aumento da expressão desse gene em camundongos. Também realizamos ensaios de gene reporter utilizando a região regulatória wildtype e a com a deleção de 216-pb para verificar o padrão de expressão tempo-espacial dessa região regulatória.

\subsubsection{Plasmídeos e ensaio de gene reporter por LacZ}

A região regulatória wild-type e a com a deleção de 216-bp foram usados para estudo de gene reporter por LacZ usando o modelo de camundongo. Para a amplificação da região regulatória foram utilizados o primer forward: 5'CACTAAAGGGAACAAAAGCTGGTACCGTGAGGGCTGAAGGATCACA-3', o qual foram adicionados nucleotídeos referentes ao sítio de restrição da enzima $K p n I$ e mais 20 nucleotídeos para Gibson assembly assay (GAA); $\mathrm{O}$ primer reverse foi 5'TTtGGATGTTCCTGGAGCTCGGTACCCCGCCCCGGATTAGGTAAA-3，， também com nucleotídeos para o KpnI e mais 19 nucleotídeos para GAA. Os produtos da PCR foram purificados de géis de agarose e clonados no vetor Hsp-68-promoter-LacZ reporter (Visel et al., 2009) conforme o protocolo do Gibson Assembly (NEB, MA, EUA). Os dois vetores, um com a 
região regulatória wild-type e outro com a deleção de 216-pb foram linearizados usando NotI, e foram injetados em embriões de camundongo por meio de microinjeção pronuclear. Embriões transgênicos foram coletados no estágio embrionário de 15 dias e meio (e15.5) e foram corados para visualizar a atividade do gene reporter LacZ (Nobrega et al., 2003). O comitê de ética em animais do Lawrence Berkeley National Laboratory (AWRC) aprovou o uso dos camundongos como modelo animal para esse estudo.

\subsubsection{Superexpressão do $K L C 2$ humano em camundongo}

Para realização do estudo transgênico da síndrome SPOAN em modelo de camundongo, nós obtivemos o Fosmídeo G248P85490B12, que daqui em diante será chamado de Fosmídeo do KLC2. Esse fosmídeo contém aproximadamente 44-kb de comprimento (chr11:66.000.28366.044.619), que inclui todo o $K L C 2$ e sua região regulatória, além de um gene vizinho $(R A B 1 B)$. O Fosmídeo do $K L C 2$ foi linearizado por $R s r I I$ (que interrompe a transcrição do $R A B 1 B$ ) e foi inserido no embrião por microinjeção pronuclear. O número de cópias do trangene nos camundongos foi detectado por qPCR usando os primers forward: 5'TGGGCAAGTTTCACCCAGAT-3' e reverse: 5'-TTCCACCTCCTCAGCTTTGC-3' (Tabela 4), usando o LightCycler ${ }^{\circledR} 480$ (Roche Diagnostics). Os primers desenhados para esse experimento se hibridam por completo no éxon 8 tanto no genoma do Homo sapiens (NM_001134775) quanto no do Mus musculus. A reação do qPCR foi normalizada usando o $D B H$ e o número de cópias do Fosmídeo do $K L C 2$ foi calculado usando o método $2^{-\triangle \Delta C T}$ (Schmittgen \& Livak, 2008). 
Tabela 4. Primers utilizados no estudo de camundongos transgênicos

\begin{tabular}{lcl}
\hline Primers & \multicolumn{1}{c}{ Sequência (5'-3') } & \multicolumn{1}{c}{ Finalidade } \\
\hline Forward & TGGGCAAGTTTCACCCAGAT & Avaliar o número de cópias do Fosmídeo do KLC2 \\
Reverse & TTCCACCTCCTCAGCTTTGC & nos camundongos transgênicos por qPCR \\
\hline Forward & CGGGCATGAGGGTTCCATAG & Checar o tamanho do Fosmídeo do KLC2 na região \\
Reverse & GGTTGGTGGGGTGCTATTCA & 5'UTR \\
\hline Forward & GCCTGGTTGTTAGCCTCTGT & Checar a presença do Fosmídeo do $K L C 2$ na região \\
Reverse & TGCCACTCAGGTGTCATTCC & central \\
Forward & GGACAGTGTGTCTCGCTCAA & Checar o tamanho do Fosmídeo do $K L C 2$ na região \\
Reverse & TTGCCTTCTGGGGCTTGTAG & 3'UTR \\
Forward & CACTGGAGATCCGGGAGAAG & Avaliar a expressão do transgene $K L C 2$ por qRT- \\
\hline Reverse & GGCCACATCTGGGTGAAACT & PCR \\
\hline
\end{tabular}

Amostras de cérebro de camundongos F1 no estágio de P10 (10 dias pós nascimento) foram coletadas para extração de RNA. A extração de RNA foi realizada usando TRIZOL e o RNA foi retrotranscrito em cDNA usando primers oligo(dT), utilizando o kit SuperScriptTM III First-strand Synthesis System (Life Technologies). A variação de expressão do KLC2 humano em camundongos foi analisada por qRT-PCR usando os primers descritos na Tabela 4, também usando o LightCycler ${ }^{\circledR} 480$ (Roche Diagnostics). Os primers desenhados para esse experimento se hibridam por completo no exon-boundary 7-8 tanto no genoma do Homo sapiens (NM_001134775) quanto no do Mus musculus. A reação do qRT-PCR foi normalizada para o endógeno da $B-A C T$ e a quantificação da expressão foi calculada usando o método $2^{-\triangle \Delta C T}$. 


\section{Resultados e discussão}

\subsection{Identificação da variante patogênica associada à síndrome SPOAN}

Neste estudo realizamos o WES na tentativa de detectar a variante patogênica em homozigose associada à síndrome SPOAN. Inicialmente realizamos a busca de variantes provavelmente patogênicas e com baixa frequência em bancos de dados populacionais $(<1 \%$ no 1000 genomas, http://www.1000genomes.org/) em genes já associados à HSPs (ver Tabela 1), e não foram identificadas variantes que pudessem ser candidatas a causar o fenótipo da doença. Em uma segunda análise restrita à região cromossômica mapeada da síndrome SPOAN (11q13), foram detectadas variantes nos genes $A C T N 3, M R P L 11, N U D T 8$ e $R B M 4 B$ presentes no WES da amostra brasileira. Além dessas variantes, detectamos variantes em homozigose em CLCF1 e RIN1 na amostra do paciente egípcio. Essas variantes foram triadas em pacientes, em controles familiares (das famílias do Brasil e do Egito) e em controles não familiares brasileiros, e foram utilizados dois critérios para exclusão de associação da variante à doença: a) Variante não detectada em homozigose em todos os pacientes; b) Variante encontrada em homozigose em controles. Três variantes foram descartadas como candidatas (RIN1, NUDT8 e CLCF1). As variantes que segregaram junto com o fenótipo (nos genes MRPL11, ACTN3 e RBM4B) são variantes de ponto (SNPs) em regiões não codificadoras, provavelmente sem efeito fenotípico significativo, e também provavelmente devem estar em desequilíbrio de ligação com a variante patogênica causadora da síndrome SPOAN. 
Tabela 5. Variantes detectadas em homozigose pelo WES na região cromossômica ligada à síndrome SPOAN.

\begin{tabular}{|c|c|c|c|c|c|c|c|c|c|c|c|}
\hline \multirow{2}{*}{ Genes } & \multirow{2}{*}{$\begin{array}{c}\text { Posição } \\
\text { cromossômica e } \\
\text { variantes }\end{array}$} & \multirow{2}{*}{$\begin{array}{l}\text { Localização } \\
\text { da variante }\end{array}$} & \multicolumn{3}{|c|}{ Pacientes } & \multicolumn{3}{|c|}{$\begin{array}{l}\text { Controles } \\
\text { familiares }\end{array}$} & \multicolumn{3}{|c|}{$\begin{array}{c}\text { Controles } \\
\text { brasileiros }\end{array}$} \\
\hline & & & $-/-$ & $+/-$ & $+/+$ & $-/-$ & $+/-$ & $+/+$ & $-/-$ & $+/-$ & $+/+$ \\
\hline CLCF1 & $67,135,092 \mathrm{~A}>\mathrm{G}$ & Exon 2 & 48 & 0 & 0 & 18 & 0 & 62 & NR & NR & NR \\
\hline RIN1 & $66,102,179 \mathrm{~A}>\mathrm{C}$ & Exon 5 & 0 & 0 & 20 & NR & NR & NR & NR & NR & NR \\
\hline MRPL11 & $66,205,845 \mathrm{C}>\mathrm{T}$ & $\mathrm{RNC}$ & 71 & 0 & 0 & 0 & 46 & 23 & 0 & 0 & 140 \\
\hline ACTN3 & $66,326,677 \mathrm{G}>\mathrm{A}$ & $\mathrm{RNC}$ & 65 & 0 & 0 & 0 & 40 & 20 & 0 & 40 & 102 \\
\hline$R B M 4 B$ & $66,444,626 \mathrm{G}>\mathrm{A}$ & $\mathrm{RNC}$ & 71 & 0 & 0 & 0 & 47 & 23 & 0 & 46 & 169 \\
\hline NUDT8 & $67,396,600 \mathrm{G}>\mathrm{C}$ & $\mathrm{RNC}$ & 29 & 1 & 0 & NR & NR & NR & 8 & 61 & 24 \\
\hline
\end{tabular}

Legenda: RNC - Região não codificadora; NR - Teste molecular não realizado; -/-, +/- e +/+ significam homozigoto para o alelo mutado, heterozigoto e homozigoto para o alelo normal, respectivamente.

Até o presente momento foram descritas variantes patogênicas em três genes associados à HSP localizadas na mesma região ou próxima a região mapeada da síndrome SPOAN (FLRT1, BSCL2 e CAPN1), porém nenhuma variante patogênica no WES dos dois pacientes foi detectada em homozigose nesses genes (Gan-Or et al., 2016). Recentemente foi identificada uma família consanguínea de origem árabe composta por 12 pacientes apresentando paraplegia espástica, atrofia ótica e neuropatia periférica, que os autores denominaram essa doença de SPOAN-like (Lossos et al., 2015). Estudos de ligação mapearam a variante patogênica dessa família na região cromossômica 1q e o sequenciamento do exoma identificou a variante c.678A>G (p.Q226Q) no IBA57 como causadora da doença. Pouco tempo depois, Debray et al. (2015) identificaram a variante patogênica c.436C $>\mathrm{T}$ (p.R146W) em homozigose em IBA57 como causadora de leucodistrofia fatal infantil. Checamos as variantes detectadas pelo WES na região de código e regiões intrônicas desse gene e nenhuma variante apareceu como candidata à síndrome SPOAN.

Após o sequenciamento do genoma completo de um paciente brasileiro, nosso grupo identificou uma deleção de 216-pb (chr11.hg19:g.66,024,557_66,024,773del) em homozigose na região regulatória upstream do $K L C 2$. Essa deleção foi detectada em homozigose em todos os 
pacientes com a síndrome SPOAN, incluindo os dois irmãos egípcios; não foi detectada em homozigose em 111 controles familiares e não foi encontrada em 600 controles brasileiros. A deleção de 216-pb sobrepõe 9-pb da região 5' UTR do maior transcrito do $K L C 2$ (NM_001134775.1). Essa variante também se sobrepõe à região regulatória que contém sítios de DNase hypersensitivity sites (DHS); se sobrepõe à diversos sítios de ligação de fatores de transcrição (TFBS); à marcas de histonas; e à metilação de DNA, podendo esta região atuar como promotor ou enhancer em diferentes tipos celulares (Ernst et al., 2011). Essa região regulatória apresenta alta conservação entre os primatas e tem baixo índice de fixação (do inglês fixation index; $\mathrm{F}_{\mathrm{ST}}$ ) entre as regiões 10-kb up e downstream do KLC2. Três SNPs localizados próximos a região da deleção (rs116801155, rs190099601 e rs76627914) também mostraram baixa frequência de $\mathrm{F}_{\mathrm{ST}}$ em diversas populações. Esses dados evidenciam que essa região é conservada, com pouca tolerância à variações.

O KLC2 é expresso em neurônios e a proteína codificada por esse gene, uma cinesina de cadeia leve, está associada ao transporte de cargas ao longo do axônio (Ebbing et al., 2008). As cinesinas são moléculas que atuam como motores responsáveis pelo transporte axonal de vesículas e organelas no sentido anterógrado ao longo do axônio por meio dos microtúbulos (Pernigo et al.., 2013; Birsa et al., 2013). A KLC2 é componente do complexo das cinesinas, juntamente com outras proteínas (KIF5A, KIF5B; Morton et al., 2010). Dessa forma, os indícios aqui apresentados sugerem que a deleção 216-pb em homozigose na região regulatória upstream do KLC2 seja causadora da síndrome SPOAN.

Estudos funcionais in vitro foram realizados para avaliar o padrão de expressão do $K L C 2$ em indivíduos com a deleção de 216-pb em homozigose em comparação com controles, por meio de qRT-PCR. Estudos funcionais in vivo utilizando o modelo animal de zebrafish foram realizados durante o período de Março a Junho de 2014 em colaboração com o Instituto de 
Biologia Molecular e Celular da Universidade de Rosário, Argentina, sob supervisão da Profa. Dra. Nora Calcaterra. Nesse período foram realizados os ensaios de knockdown e superexpressão do klc2 em embriões de zebrafish. A variante patogênica da síndrome SPOAN (deleção de 216pb em homozigose localizada no cromossomo 11) e os resultados e discussão dos estudos funcionais in vitro e in vivo validando a superexpressão do $K L C 2$ como causa dessa síndrome foram publicados no periódico internacional Human Molecular Genetics. O artigo encontra-se na íntegra abaixo.

\subsection{Artigo publicado na revista Human Molecular Genetics}




\title{
Overexpression of KLC2 due to a homozygous deletion in the non-coding region causes SPOAN syndrome
}

\author{
Uirá S. Melo ${ }^{1, \dagger}$, Lucia I. Macedo-Souza1,†, Thalita Figueiredo ${ }^{2,3}$, Alysson R. \\ Muotri' ${ }^{4}$, Joseph G. Gleeson ${ }^{5}$, Gabriela Coux ${ }^{6}$, Pablo Armas ${ }^{6}$, Nora B. Calcaterra ${ }^{6}$, \\ João P. Kitajima ${ }^{7}$, Simone Amorim ${ }^{8}$, Thiago R. Olávio ${ }^{1}$, Karina Griesi-Oliveira ${ }^{1}$, \\ Giuliana C. Coatti ${ }^{1}$, Clarissa R.R. Rocha ${ }^{9}$, Marinalva Martins-Pinheiro ${ }^{9}$, \\ Carlos F.M. Menck ${ }^{9}$, Maha S. Zaki ${ }^{10}$, Fernando Kok ${ }^{1,7}$, Mayana Zatz ${ }^{1, *}$ \\ and Silvana Santos, 2,3
}

\begin{abstract}
${ }^{1}$ Human Genome and Stem Cell Research Center, Department of Genetics and Evolutionary Biology, Biosciences Institute, University of Sao Paulo (USP), Sao Paulo, SP 05508-090, Brazil, ${ }^{2}$ Northeast Biotechnology Network (RENORBIO), Federal University of Paraiba (UFPB), Joao Pessoa, PB 58051-900, Brazil, ${ }^{3}$ Department of Biology, Paraiba State University (UEPB), Campina Grande, PB 58429-500, Brazil, ${ }^{4}$ Department of Pediatrics/Rady Children's Hospital San Diego, University of California San Diego, La Jolla, CA 92093, USA, ${ }^{5}$ Laboratory for Pediatric Brain Disease, The Rockefeller University, New York, NY 10065, USA, ${ }^{6}$ Instituto de Biología Molecular y Celular de Rosario (IBR), Consejo Nacional de Investigaciones Científicas y Técnicas (CONICET) - Facultad de Ciencias Bioquímicas y Farmacéuticas, Universidad Nacional de Rosario (UNR), Rosario, SF S2002LRK, Argentina, ${ }^{7}$ Mendelics Genomic Analysis, São Paulo, SP 04013-000, Brazil, ${ }^{8}$ Department of Neurology, School of Medicine, University of Sao Paulo (USP), São Paulo, SP 01246-903, Brazil, ${ }^{9}$ Department of Microbiology, Institute of Biomedical Sciences, University of São Paulo (USP), São Paulo, SP 05508-900, Brazil and ${ }^{10}$ Department of Clinical Genetics, Human Genetics and Genome Research Division, National Research Center, Cairo 12311, Egypt

*To whom correspondence should be addressed at: Rua do Matao, 277, Cidade Universitária, São Paulo, SP CEP 05508-900, Brazil. Tel: +55 1130917563; Fax: +55 1130917419; Email: mayazatz@usp.br
\end{abstract}

\begin{abstract}
SPOAN syndrome is a neurodegenerative disorder mainly characterized by spastic paraplegia, optic atrophy and neuropathy (SPOAN). Affected patients are wheelchair bound after 15 years old, with progressive joint contractures and spine deformities. SPOAN patients also have sub normal vision secondary to apparently non-progressive congenital optic atrophy. A potential causative gene was mapped at 11q13 ten years ago. Here we performed next-generation sequencing in SPOAN-derived samples. While whole-exome sequencing failed to identify the causative mutation, whole-genome sequencing allowed to detect a homozygous 216-bp deletion (chr11.hg19:g.66,024,557_66,024,773del) located at the non-coding upstream region of the KLC2 gene. Expression assays performed with patient's fibroblasts and motor neurons derived from SPOAN patients showed KLC2 overexpression. Luciferase assay in constructs with 216-bp deletion confirmed the overexpression of gene reporter, varying from 48 to $74 \%$, as compared with wild-type. Knockdown and overexpression of klc2 in Danio rerio revealed mild to severe
\end{abstract}


curly-tail phenotype, which is suggestive of a neuromuscular disorder. Overexpression of a gene caused by a small deletion in the non-coding region is a novel mechanism, which to the best of our knowledge, was never reported before in a recessive condition. Although the molecular mechanism of KLC2 up-regulation still remains to be uncovered, such example adds to the importance of non-coding regions in human pathology.

\section{Introduction}

Hereditary spastic paraplegias (HSPs) are common neurodegenerative genetic disorders in which patients present progressive spasticity and lower limbs weakness. Up to date, more than 70 loci had been associated with HSPs and at least 50 genes have been identified (1). In 2005, our group identified in a geographic isolate in the backlands of Northeastern Brazil, 26 Caucasian individuals belonging to consanguineous families with an autosomal recessive (AR) complicated form of HSP, which associates spastic paraplegia, optic atrophy and neuropathy (SPOAN syndrome, OMIM \#609541) (2). This condition is characterized by onset of progressive spastic paraplegia in infancy, and progressive motor and sensory axonal neuropathy in late childhood/ early adolescence leading to severe motor disability. All patients are wheelchair bound after 15 years old, with progressive joint contractures and spine deformities. Patients also have sub normal vision secondary to apparently non-progressive congenital optic atrophy, dysarthria starting in the third decade of life and exacerbated acoustic startle response. Patients show no intellectual impairment. Ten years after the gene mapping, more than 70 individuals from this cluster, three unrelated affected individuals from Southern and Southeast Brazil, and a pair of Egyptian siblings were diagnosed with SPOAN. Although, all patients share the same haplotype spanning $2.3 \mathrm{Mb}$ into chromosome region $11 \mathrm{q} 13$, Sanger sequencing of candidate genes failed to reveal the causative gene (3). Here we describe the SPOAN causative mutation, a small deletion in the non-coding region that causes gene overexpression. Gain of function in a recessive condition is a novel mechanism that, to the best of our knowledge, was never reported before.

\section{Results}

\section{Next-generation sequencing and SPOAN mutation}

Whole-exome sequencing (WES) was performed in genomic DNA from one Brazilian and one Egyptian patient diagnosed with SPOAN syndrome. We identified six homozygous variants at the critical region, but population frequency and segregation analysis excluded four variants, while the remaining two were SNPs located in non-coding region, suggesting that these two were unlikely to be associated to the clinical phenotype (Supplementary Material, Table S1). Although WES failed to reveal the SPOAN mutation, the sequencing allowed us to refine the critical interval on chromosome $11 \mathrm{q} 13$ to $1.77 \mathrm{Mb}$, between markers rs508548 ( $\mathrm{A}>\mathrm{G}$ at $65,626,289$ position in CFL1) and an undescribed variant located at $67,395,410$ (G>C in NUDT8). Next, using wholegenome sequencing (WGS), we identified a homozygous 216-bp deletion (chr11.hg19:g.66,024,557_66,024,773del), located at the non-coding upstream region of kinesin light chain-2 (KLC2) (Supplementary Material, Fig. S1). This variant was detected in homozygosity in all affected Brazilian individuals $(n=73)$, and in the Egyptian affected siblings, while it was not present in homozygosity in 111 healthy Brazilian relatives. This 216-bp deletion was also absent in 474 Brazilian healthy controls and is not described in the 1000 genomes database.

\section{Gene expression analysis}

To verify if the deletion affects the expression level of genes located in SPOAN critical region, we performed expression array using cDNA from fibroblasts. Several genes ( $n=23$; Supplementary Material, Table S2) showed differential expression in patients compared with controls $(P<0.01)$. Unexpectedly, this assay revealed KLC2 overexpression. Quantitative reverse transcription PCR (RT-qPCR) performed using fibroblast cDNA samples confirmed the expression array results (Fig. 1A). We next generated induced pluripotent stem-cells (iPSC) which were differentiated into motor neurons (MN). RT-qPCR using MN samples revealed KLC2 up-regulation in SPOAN patients compared with healthy controls, confirming the over expression observed in the previous experiments (Fig. 1C). Also we investigated KLC2 expression in blood, using a larger number of cDNA samples from healthy controls, heterozygotes and affected individuals. This assay did not reveal any difference in expression levels between heterozygotes compared with SPOAN's and to healthy controls (Fig. 1E).

To investigate if the 216-bp deletion is the cause of KLC2 upregulation, we performed luciferase gene reporter assay using three cell lines (HEK293T, U87MG and MN), which were transfected with two constructs: a KLC2 wild-type promoter and KLC2 216-bp deleted regulatory region driving the Luciferase gene. In the three cell lines, the construct with the 216-bp deletion produced a luciferase activity increment compared with wild-type promoter, varying from 48 to $74 \%$ (Fig. 1F).

\section{Klc2 knockdown and overexpression in Danio rerio}

We then used Danio rerio as an animal model to study the 'in vivo' effect of klc2 knockdown and overexpression. Knockdown regulation was achieved by microinjecting zebrafish embryos with two different klc2 morpholinos (translation blocking morpholino $\left[\mathrm{MO}^{\mathrm{klc2}-\mathrm{TB}}\right]$ and splice morpholino $\left.\left[\mathrm{MO}^{\mathrm{klc} 2 \mathrm{SP}}\right]\right)$, each one at doses of 4 and $6 \mathrm{ng}$. Mild phenotype was defined for embryos showing curly-tail and circular swimming whereas severe phenotype for embryos with dramatically shortened and twisted tail and that were unable to swim. Both phenotypes became evident at $48-\mathrm{h}$ post fertilization (hpf) (Fig. 2A). In all cases, statistically significant differences were observed between mismatch-MO and specific-MO injected embryos. For both morpholino strategies when comparing to the respective mismatch-MO controls, an increase in lethality and/or frequency of phenotypes was mainly observed in detriment of normal phenotype. Furthermore, this difference was more evident when higher amount of either $\mathrm{MO}^{k l c 2-\mathrm{TB}}$ or $\mathrm{MO}^{\text {klc2-SP }}$ was injected (Fig. 2B). Phenotype rescue assays were performed by coinjection of $100 \mathrm{pg}$ of $\mathrm{mRNA}^{\text {klc2-eGFP }}$ and splice morpholino at $6 \mathrm{ng}$ (Fig. $2 \mathrm{C}$ ), and an improvement of $\sim 33 \%(\mathrm{P}<0.01)$, from severe to mild phenotype, was consistently observed (Fig. 2D).

As SPOAN syndrome seems to result from KLC2 up-regulation, we mimicked this condition in zebrafish by microinjecting $\mathrm{mRNA}^{\text {klc2-eGFP }}$ in specific concentrations in embryos. Fluorescent embryos displayed similar phenotype to klc2 morphants (Fig. 3A). A high lethality (over than $70 \%$ ) was observed in embryos microinjected with mRNA ${ }^{\text {klc2-eGFP }}$ at $200 \mathrm{pg}$ at 24-hpf stage and we excluded this concentration data in phenotype analysis (Fig. 3B). We observed higher frequency of curly-tail phenotype in 
A

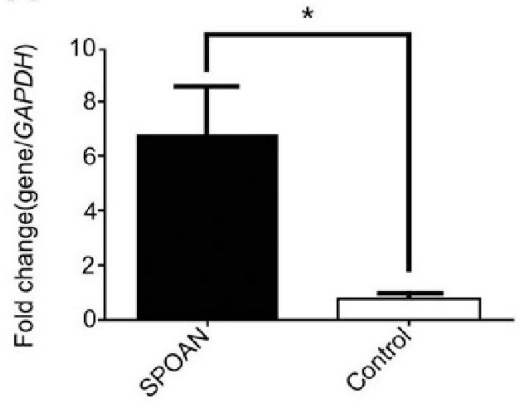

B

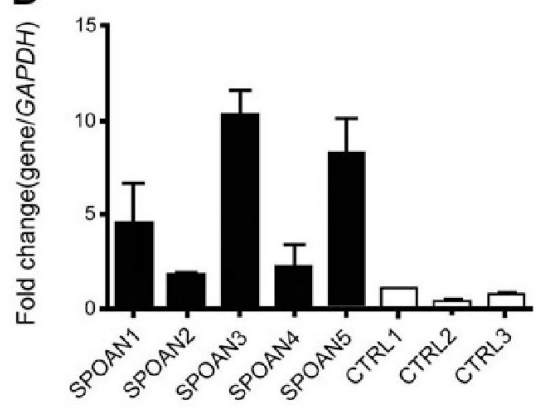

C

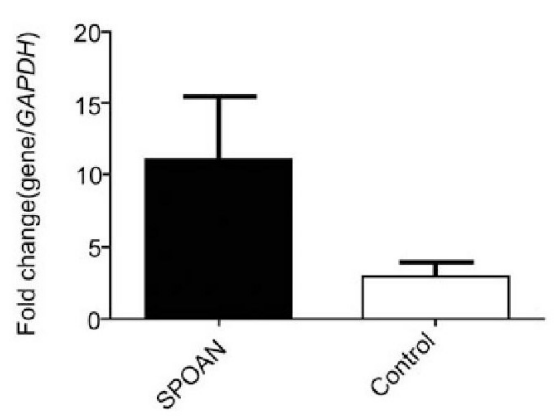

D

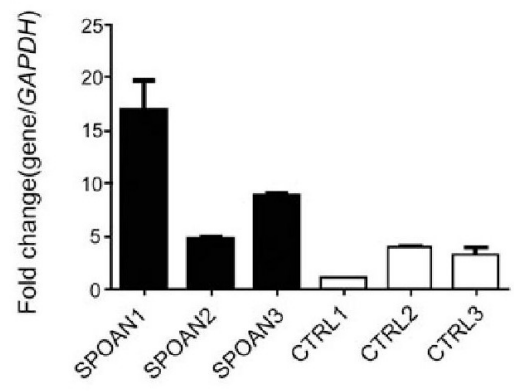

E

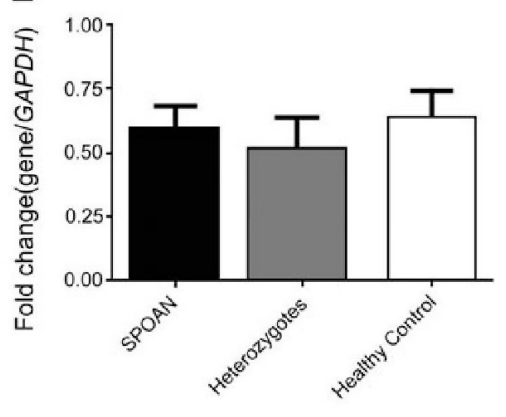

F

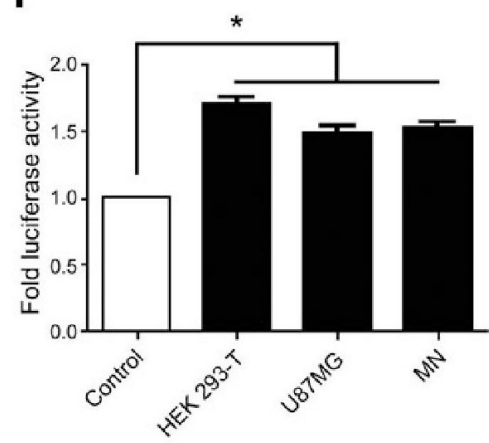

Figure 1. Effect of 216-bp deletion on KLC2 expression. (A) Relative expression of KLC2 measured by RT-qPCR performed on fibroblast cDNA isolated from SPOAN patients and healthy controls $(\mathrm{P}<0.05$; Nonparametric test [Mann-Whitney]). (B) KLC2 relative expression measured on fibroflast samples from individual patients and healthy controls. (C) Relative expression of KLC2 measured by RT-qPCR using MN. (D) KLC2 relative expression measured on MN samples from individual patients and healthy controls. (E) KLC2 relative expression measured on whole-blood cDNA samples from affected (homozygotes), heterozygotes and healthy controls. Each RT-qPCR experiment was performed in triplicate and each sample was replicated twice. (F) Expression of luciferase reporter gene controlled by the 216-bp-deleted KLC2 regulatory region relative to the expression controlled by the wild-type KLC2 regulatory region measured in HEK293 T, U87MG and MN cells. Each experiment was performed in triplicate and each cell type was replicated twice $(P<0.05$; One-way ANOVA).

embryos microinjected with mRNA ${ }^{\text {klc2-eGFP }}$ compared with control (mRNA ${ }^{\text {eGFP }}$ ), being statistical significant in embryos microinjected at $150 \mathrm{pg}$ mRNA concentration $(P<0.05)$ (Fig. 3C).

\section{Discussion}

We previously mapped the SPOAN gene, responsible for a syndromic form of AR spastic paraplegia, at 11q13 (2,3). Based on next-generation sequencing, we were able to uncover a new causative mechanism for this condition. We observed that a small deletion in KLC2 non-coding region is responsible for the gene up-regulation and SPOAN phenotype. Additionally, BSCL2 and FLRT1, two genes previously associated with HSP and located nearby but outside the 11q13 critical region, were excluded as candidates $(4,5)$. The Egyptian patients reported in this study as SPOAN carried the c.T2023C (stop loss) homozygous mutation in FLRT1, and were previously assigned by Novarino et al. (5) (Family 709) as SPG68. However, here we suggest that 216-bp deletion, shared by all SPOAN patients, is probably the causative mutation in both Egyptian siblings, rather than the reported FLRT1 mutation.

KLC2 codes for KLC2, a protein involved in anterograde axoplasmatic transport of organelles and macromolecules cargoes (6-10). KLC2 is a part of kinesin protein-1 complex (11), which binds to kinesins heavy chain in a stoichiometric ratio of 1:1 (12), being highly expressed in neurons. Several neurodegenerative diseases show impairment in axonal transport $(13,14)$ and some kinesins heavy chains (KIF5A, KIF1A and KIF1C) have been associated with HSP (15-18). Animal models have also shown that disturbance of axonal transport proteins cause neurodegenerative disease and axon degeneration (10,19-21). Although the disease mechanism described here involves a homozygous deletion in a non-coding region, all these observations strongly suggest that KCL2 is the causative gene for SPOAN.

According to the RepeatMask database, KLC2 upstream region was generated by a non-LTR retrotransposon (L3/CR-1) insertion. DNA footprint and alignment of L3/CR-1 did not show conservation among distant species, but the high conservation observed among primates suggests it was inserted during the divergence of primates from other mammals. In several human populations, KLC2 surrounding region (10-kb up- and downstream) and three described SNPs surrounding the mutation location have low fixation index $\left(\mathrm{F}_{\mathrm{ST}}\right)$ (Supplementary Material, Fig. S2) (rs116801155, rs190099601 and rs76627914 with $\mathrm{F}_{\mathrm{ST}}$ of $0.0044,0.0002$ and 0.0427 , respectively), indicating a high conservation in humans.

Surprisingly, the small deletion in its non-coding upstream region causes KLC2 overexpression, suggesting a novel molecular mechanism never report before, a gain of function in recessive condition. Intriguingly, the 216-bp deletion overlaps 9-bp of $5^{\prime}$-untranslated region (5'-UTR) of the largest KLC2 transcript (NM_001134775.1), which means that this mutation is located at KLC2 promoter region (upstream of the transcription start site [TSS]) and it should cause gene downregulation instead gain of function. Although this region has characteristics of a promoter (enrichment of H3Kme3, DNase I hypersensitive sites [DHS], RNA pol II binding sites, etc.), transcription factors complexes that bind at this region may act as transcriptional repressor, which could explain the gene up-regulation. Additionally, this 

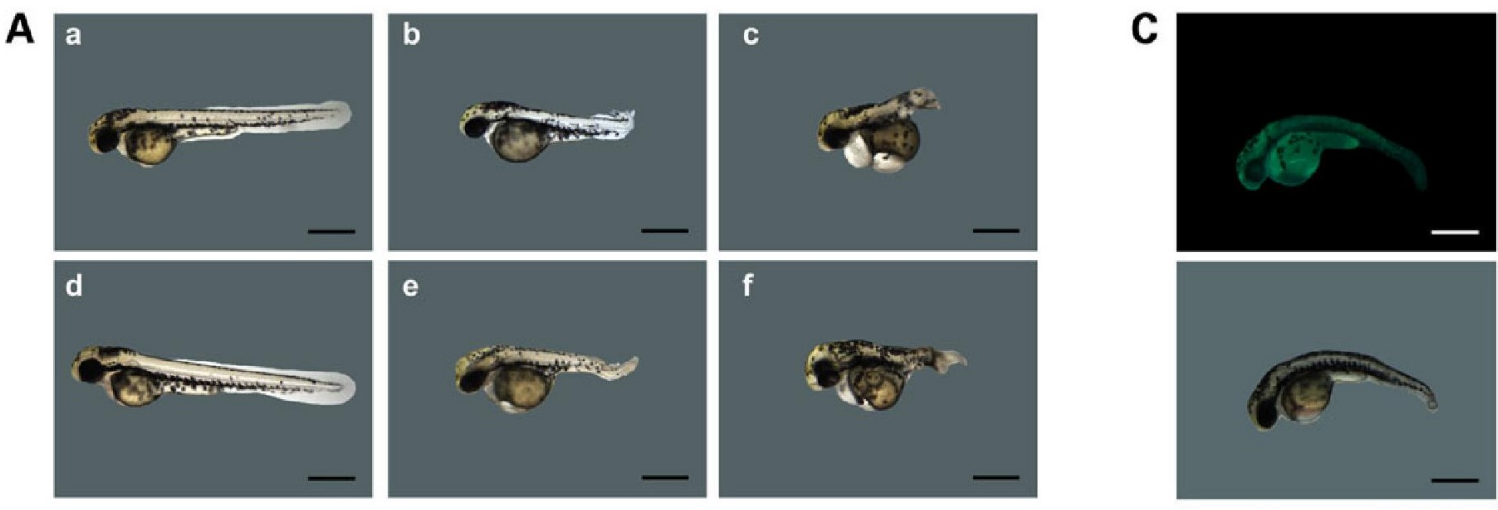

B
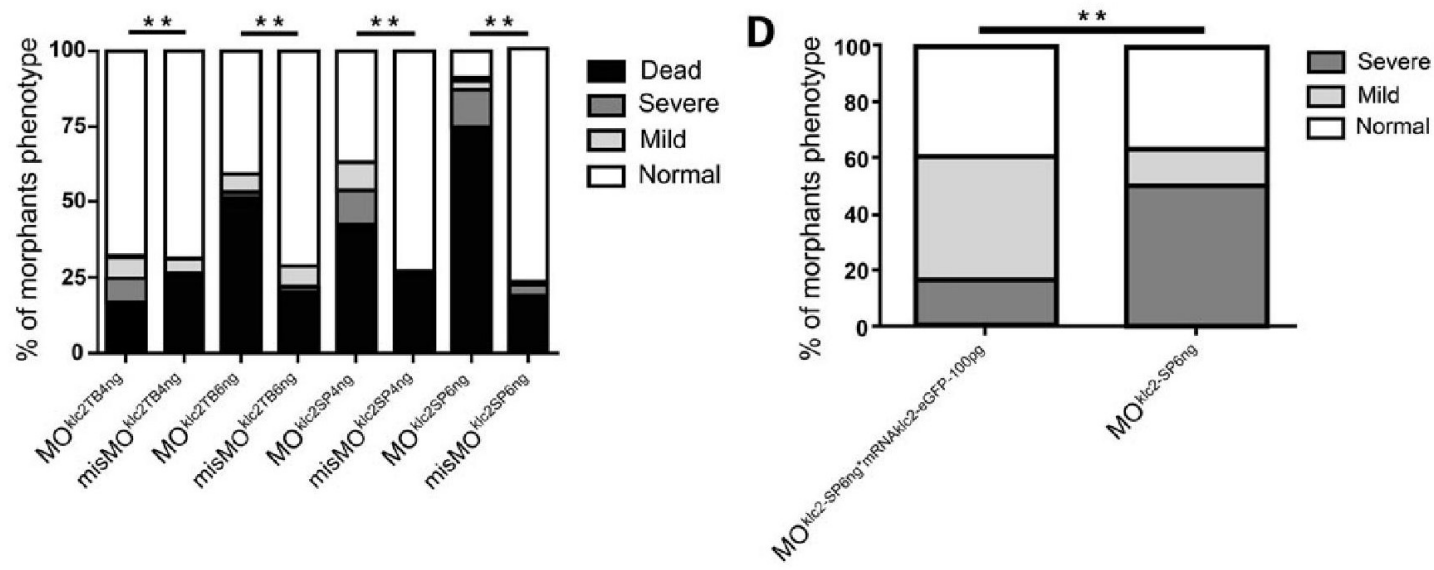

Figure 2. Effect of klc2 knockdown in zebrafish. (A) (a and d) Embryos microinjected with control splicing blocking morpholino: (a) misMO ${ }^{k l c 2-s P 4 n g}$ (d) misMO ${ }^{\text {klc2-SP6ng }}$

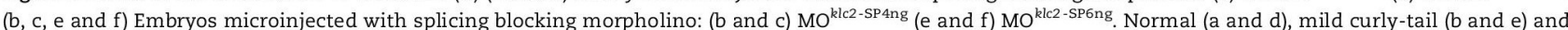
severe curly-tail (c-f) phenotypes were recorded at 48-hpf. (B) Frequencies of observed phenotypes among morphants. Number of microinjected embryos: MO ${ }^{\text {klc2-TB4ng }}$

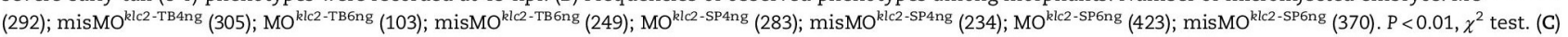
Fluorescent embryo coinjected with $6 \mathrm{ng} \mathrm{MO} \mathrm{O}^{\mathrm{klc2}-\mathrm{SP}}$ and $100 \mathrm{pg} \mathrm{mRNA}{ }^{\text {klc2-eGFP }}$ (selected by fluorescence at 24-hpf) showing mil-curly tails was recorded at 48-hpf. Scale bar $200 \mu \mathrm{m}$. (D) Embryos coinjected with $6 \mathrm{ng} \mathrm{MO} \mathrm{O}^{k l c 2-S P}$ and $100 \mathrm{pg} \mathrm{mRNA}{ }^{k l c 2-e G F P}$ ( $n=70$ embryos) showed a partial rescue of morphant phenotype compared with $\mathrm{MO}^{\mathrm{klc} 2 \text {-SPGng }}\left(n=30\right.$ embryos). $P<0.01, \chi^{2}$ test.

deletion overlaps an unspliced antisense long non-coding RNA (lncRNA, AU311830.1) and regulatory elements: DHS, several transcription factors binding sites (TFBS), histone marks and DNA methylation (Supplementary Material, Fig. S1). Thus, a disruption of this non-coding and regulatory region might alter the expression level of downstream genes, which can explain SPOAN gain of function.

Expression analysis showed an unexpected KLC2 overexpression from fibroblast and MN SPOAN samples. Because SPOAN is a recessive condition, we tried to check the KLC2 expression pattern in heterozygous samples. Whole-blood samples collected from a large number of heterozygotes did not reveal increased KLC2 expression, when compared with homozygotes and healthy controls. These results suggest a tissue-specific effect since 216-bp deletion causes KLC2 up-regulation in fibroblast and MN cell-lines, but does not in blood. Also, luciferase assay showed that reporter constructs with 216-bp deletion have increased luciferase activity when compared with the wild-type. These results support the hypothesis that the 216-bp deletion located at non-coding region is likely the responsible for the KLC2 overexpression.

Zebrafish has been an interesting animal model used in genetic studies due to its fast embryonic development and the fact it carries several human orthologues genes. The percentages of lethality and animals with curly-tail phenotype observed in morphants in this study were similar to those reported in several reports that employed zebrafish for other HSP (22-28). Microinjection of mRNA klc2-eGFP in zebrafish embryos showed a similar phenotype of klc2 morphants, which reinforces our hypothesis that klc2 is an essential gene for MN function and development. Thus, we hypothesize that imbalance of KLC2 gene expression results in neurodegenerative phenotype in humans.

Gene overexpression had been associated with several neurological disorders but none of them have AR inheritance. For example, duplication or triplication of PLP1 cause Pelizaeus-Merzbacher disease (OMIM \#312080) (29-33) and PMP22 duplication causes Charcot-Marie-Tooth disease type 1A (OMIM \#118220), a hereditary demyelinating neuropathy $(34,35)$. Variants detected upstream APP region were associated with up-regulation of APP protein in Alzheimer disease and Down syndrome patients (36) Additionally, downregulation or complete disruption of protein synthesis is usually the common mechanism in HSP in which functional studies have been conducted. For instance, this is the case in X-linked [e.g. L1CAM (37)], autosomal dominant [e.g. ATL1 (38) and SPAST (39)] and AR conditions [as SPG20 (40) and FA2H (41)]

In short, several unexpected and surprising results were observed during SPOAN syndrome molecular investigation. Although the molecular mechanism of this up-regulation still 
A
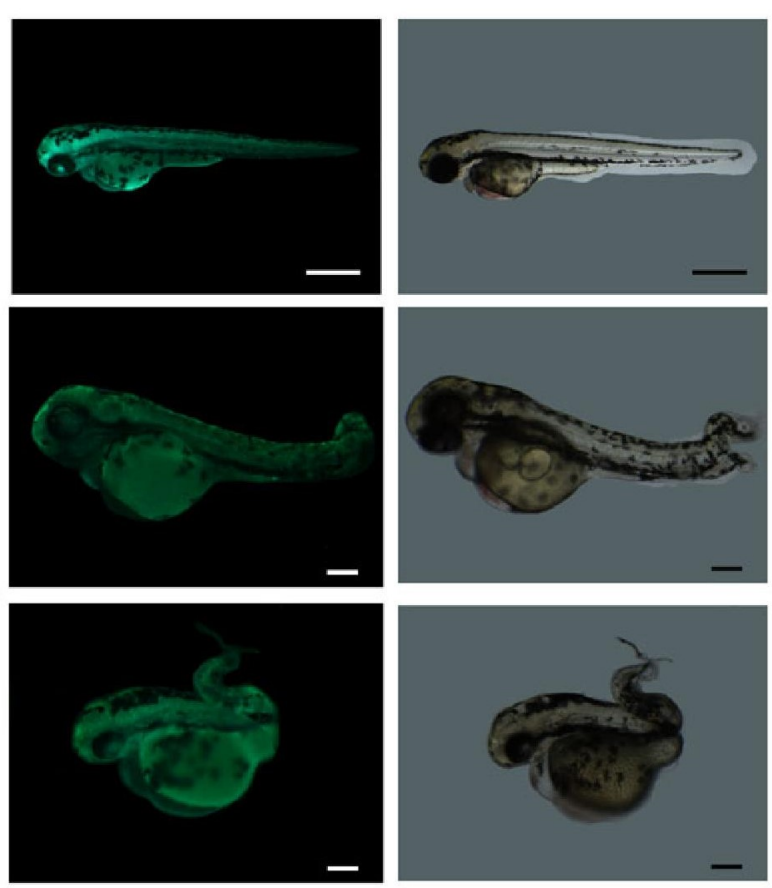

B

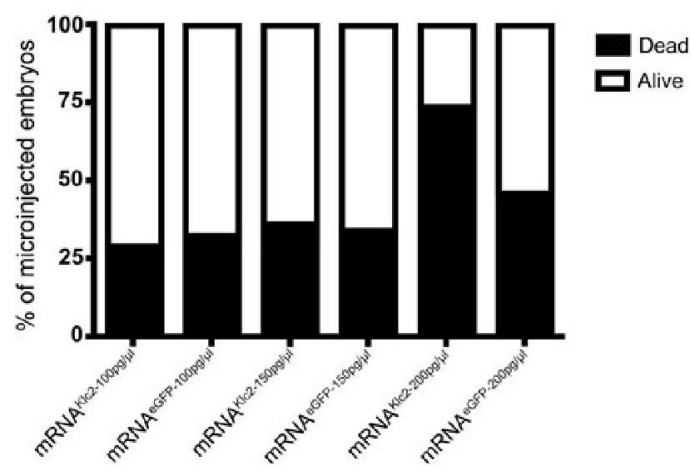

C

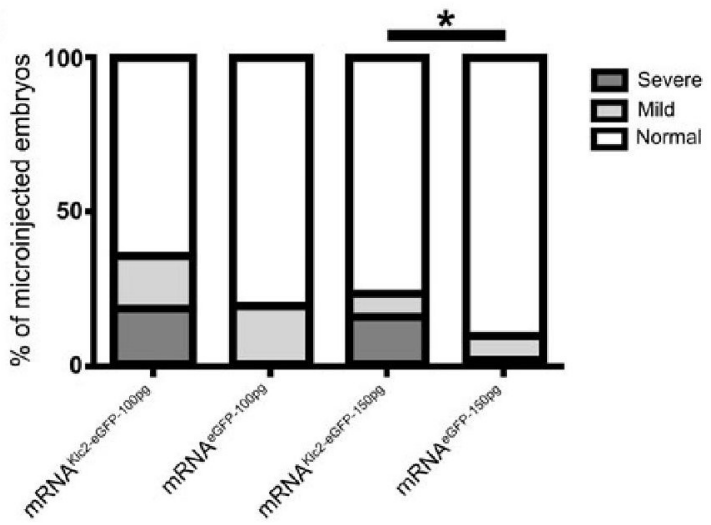

Figure 3. Effect of klc2 overexpression in zebrafish. (A) (a and b) Embryos microinjected with $100 \mathrm{pg}$ of mRNA ${ }^{\mathrm{eGFP}}$ and (c-f) embryos microinjected with 100 pg of mRNA $^{\text {klc2-eGFP }}$ were selected by fluorescence at 24-hpf, and recorded at 48-hpf. (a and b) Normal Embryos, (c and d) mild curly-tail and (e and f) severe curly-tail phenotypes. Scale bars: (a and b) $200 \mu \mathrm{m}$; (c-f) $100 \mu \mathrm{m}$. (B) Lethality frequency observed in embryos at 24-hpf stage. Embryos microinjected with 200 pg mRNA $\mathrm{m}^{\mathrm{kl} 2 \text {-eGFP }}$ showed high lethality and were excluded form phenotype analysis. (C) Frequencies of observed phenotypes among GFP-fluorescent embryos. Numbers of embryos selected by fluorescence: $\mathrm{mRNA}^{\text {klc2-eGFP-100pg }}=32 ; \mathrm{mRNA}^{\text {eGFP-100pg }}=16 ; \mathrm{mRNA}^{\text {klc2-eGFP-150pg }}=43 ; \mathrm{mRNA}^{\text {klc2-eGFP-150pg }}=52$. $P<0.05, \chi^{2}$ and Fisher's exact tests.

remains to be uncovered, it adds another example of the importance of non-coding regions in human pathology.

\section{Materials and Methods}

\section{Patients}

Clinical information regarding SPOAN patients in the geographic cluster detected in northeastern Brazil was detailed elsewhere $(2,3)$. Additionally, we evaluated another three Brazilian patients, with different ancestors from northeastern Brazil and two Egyptians siblings with the identified 216-bp deletion and same clinical symptoms. Blood samples were used for DNA extraction from all patients, from several obligated carriers and from unaffected siblings. Fibroblasts were obtained from dermal biopsies from five patients, one heterozygote and four Brazilian healthy controls, following informed consent under protocols approved by the Biosciences Institute, University of São Paulo (Protocol CEP 010/2003).

\section{Molecular analysis}

Previous studies conducted by our group using Sanger sequencing did not identify deleterious variants in exons of candidates genes located in the critical region for SPOAN (LRFN4, KLC2 and CCS) (3). To have a more comprehensive and detailed view over this region, WES was performed using DNA samples from two SPOAN subjects using Agilent SureSelect Human All Exon $50 \mathrm{Mb}$ Kit and sequenced in Illumina HiSeq2000 (Illumina, San Diego, CA, USA). Alignment against reference GRCh37 was performed with BWA (42); genotyping with GATK (43); SNP and InDel annotation with Annovar (44) and CNV detection with the $\mathrm{R}$ package ExomeDepth (45). The WES coverage achieved at the candidate region was $40 x$ and $77 x$ in the Egyptian and Brazilian samples, respectively. The 216 -bp deletion was not detectable by WES. Variants detected in the mapped linkage region were filtered by their frequency, compared with 1000 Genomes database, NHLBI GO Exome Sequencing Project (ESP), Exome Aggregation Consortium (ExAC) and with sequences obtained from 1484 Brazilian controls.

Whole-genome sequencing was performed in DNA from a third affected patient (a distant cousin from Brazilian series) using Illumina TruSeq DNA kit. Alignment against reference GRCh37 was performed with BWA (42); genotyping with GATK (43); SNP and InDel annotation with SnpEff (46) and CNV detection using R package ExomeDepth (45) restricted to exon regions (using bedfile template of the Agilent V4Plus kit), Pindel and additional manual screening in the target linkage region. The achieved coverage at the candidate region was $26 \times$. Variants were filtered by comparison with 1000 Genomes. SPOAN mutation (chr11.hg19:g.66,024,557_66,024,773del) was checked for cosegregation in affected and family health controls (also checked in 474 unrelated health controls) by PCR followed by agarose gel electrophoresis using primer ID 1 (Supplementary Material, Table S3).

\section{Induced pluripotent stem-Cells (iPSC)}

Retrovirus vectors containing the Oct4, c-Myc, Klf4 and Sox2 human cDNAs were obtained from Muotri's group and the 
protocol is described elsewhere (47). Embryoid bodies (EBs) were formed by mechanical dissociation of cell clusters (pre-treated with dorsomorphin, $1 \mathrm{nM}$, for 2 days) and plating onto low-adherence dishes in NB media (DMEM/F12 plus 0.5X N2 and 0.5X B27 supplements) plus dorsomorphin for 2 days and in the next 5 days in NB media plus FGF and EGF. After that, mature EBs were dissociated with accutase for $5 \mathrm{~min}$ at $37^{\circ} \mathrm{C}$ and plated in matrigel in NB media plus FGF $20 \mathrm{ng} / \mathrm{ml}$ and EGF $20 \mathrm{ng} / \mathrm{ml}$. Rosettes were visible for collection after 7 days and were then dissociated with accutase (Chemicon, EMD Millipore, Darmstadt, Germany) and plated onto poly-ornitine/laminin-coated dishes (Sigma) with NB media plus FGF and EGF. Homogeneous populations of neural progenitor cells (NPCs) were achieved after 1-2 passages with accutase in the same condition. To improve cell differentiation, brain-derived neurotrophic factor $(20 \mathrm{ng} / \mathrm{ml})$, glial cellderived neurotrophic factor $(20 \mathrm{ng} / \mathrm{ml})$, insulin-like growth factor-1 $(20 \mathrm{ng} / \mathrm{ml})$, Ri $(5 \mathrm{uM})$ and SHH $(100 \mathrm{ng} / \mathrm{ml}$; neuronal maturation medium) were added to neuronal cultures for 5 weeks. NPCs were differentiated in MN following a protocol modified from study described elsewhere (48).

\section{Human RNA extraction and cDNA synthesis}

RNA extraction from fibroblasts ( $n=5$ affected; $n=1$ heterozygote; $n=4$ healthy controls) and MN ( $n=3$ affected; $n=1$ heterozygote; $n=3$ healthy controls) was performed with TRIZOL $\Theta$ reagent (Invitrogen) and Norgen Biotek RNA/DNA/Protein Purification Kit (Norgen Biotek Corp., Ontario, Canada); RNA from wholeblood ( $n=7$ affected; $n=7$ heterozygotes; $n=6$ family healthy controls +1 unrelated healthy control from the same region) were extracted using PAXgene Blood RNA Kit (Qiagen); RNA was reverse-transcribed with oligo(dT) primers using SuperScript $\mathrm{t}^{\mathrm{TM}}$ III First-strand Synthesis System (Life Technologies).

\section{Expression array}

Fibroblast cDNA samples were submitted to array expression assay using GeneChip ${ }^{\circledR}$ Scanner $30007 \mathrm{G}$ System (Affymetrix, Santa Clara, CA, USA). The results of expression array were normalized by Robust Multi-array Average (49) and statistical method (test-T) was performed using CLCbio Genomics Workbench, adjusted by Bonferroni and false discovery rate (FDR). Data weresubmitted to GEO (accession number: GSE67527).

\section{Quantitative reverse transcription PCR (RT-qPCR)}

KLC2 primers for RT-qPCR were detailed in Supplementary Material, Table S3 (primer ID 2). RT-qPCR was normalized to GAPDH and was performed using LightCycler $\circledast 480$ (Roche Diagnostics). KLC2 expression data were calculated using $2^{-\Delta \Delta C T}$ method (50). Mann-Whitney test (Nonparametric) was performed using GraphPad Prism version 5.00 (San Diego, CA, USA). Each experiment was performed in triplicate and each sample was replicated twice.

TaqMan Gene Expression Assay probes: MNX1/HB9 (Hs00907365 m1), CHAT (Hs00252848_m1) and ISL1 (Hs00158126_m1) were used to validate the neurons derived cells from iPSC as MN (Applied Biosystems, USA). RT-qPCR was normalized to Human ACTB ( $\beta$-actin; Hs01060665_g1). RT-qPCR was performed using the Applied Biosystems ${ }^{\circledR} 7500$ Fast Real-time PCR System.

\section{Immunofluorescence and MN validation}

For immunofluorescence evaluation of MN, cells were fixed with $4 \%$ paraformaldehyde, followed by permeabilization and blocking with $0.05 \%(\mathrm{v} / \mathrm{v})$ Triton X in PBS containing $5 \%(\mathrm{v} / \mathrm{v})$ donkey serum. Primary antibodies were incubated overnight at $4^{\circ} \mathrm{C}$. Samples were washed three times before secondary antibodies incubation (Alexa Fluor Dyes, Life Technologies). Dapi was added in the last $20 \mathrm{~min}$ of secondary antibody incubation. Primary antibody concentrations were: a-NeuN mouse monoclonal 1:500 (Millipore); a-Hb9 mouse polyclonal 1:500 (DSHB) and a-Islet 1 rabbit polyclonal 1:1000 (BD Bio-science). Images were obtained through Axio Observer.A1 immunofluorescence microscope (Zeiss). cDNA obtained from fibroblasts, NPC and MN were used for MN validation using TaqMan probes described above. RTqPCR using fibroblast samples did not show expression of MN probes. RT-qPCR of MN samples showed expression of MNX1/ HB9 probe, which was not amplified in NPC samples. MN samples showed higher significant $(P<0.05)$ expression of CHAT compared with NPC (Supplementary Material, Fig. S3B). We confirmed the presence of 216-bp deletion in DNA extracted from MN patient samples (Supplementary Material, Fig. S3C).

\section{Gene reporter assay}

The full-length (3,313-bp) and deleted 216-bp (3,097-bp) KLC2 upstream region was synthesized (Genone) and cloned into promoterless firefly luciferase vector pGL4 (Promega). pShuttle/RL was used for transfection normalization, which expresses the reporter gene Renilla luciferase (51). Assays using HEK239T, U87MG and MN about $1 \times 10^{4}$ cells were plated in 96-well dishes in triplicate for each point. In HEK239T and U87MG a total of $200 \mathrm{ng}$ of plasmids (180 ng pGL4 and 20 ng pShuttle/RL) were used for transfection using Lipofectamine 2000 Transfection Reagent (Invitrogen). In MN we used 480 ng pGL4 and 20 ng pShuttle/RL. Two days after DNA transfection, the luciferase activities were measured in Glomax luminometer (Promega) with the Dual-Glo Luciferase Assay System (Promega) according to manufacturer's instructions. One-way ANOVA was performed using GraphPad Prism version 5.00 (San Diego, CA, USA).

\section{Zebrafish animal model}

Adult zebrafish were maintained at $28^{\circ} \mathrm{C}$ on a $14 \mathrm{~h}$ light/10 $\mathrm{h}$ dark cycle and the embryos were obtained by natural mating. Zebrafish presents only one klc2 gene in its genome (ZFIN ID: ZDBGENE-030131-2670), which turns appropriate the use Danio rerio as animal model in this study. The use of Danio rerio in this study was approved by the Committee on the Ethics of Animal Experiments of Pharmacology and Biochemistry Sciences department of National University of Rosario, Argentina (No. 429/2014).

\section{Zebrafish RNA extraction and cDNA synthesis}

Total RNA was extracted from whole embryos at different embryonic stages (6, 24, 48 and 72-hpf). RNA extraction was performed using TRIZOL $®$ reagent (Invitrogen), following the manufacturer's protocol. First-strand cDNA was synthetized using SuperScript Reverse Transcriptase (Invitrogen) with a specific primer (primer ID 3) for Danio rerio klc2 gene transcript (Ensembl ENSDARG00000075485). The complete klc2 CDS was amplified by PCR using primers ID 4, forward including EcoRI and reverse including SacI restriction sites.

\section{Plasmids and DNA constructs}

The complete CDS sequence from klc2 $\left(\mathrm{mRNA}^{k l c 2}\right)$ was cloned using EcoRI and Sacl sites into an engineered version of pCS2 $+\mathrm{MT}$ as described elsewhere (52). This plasmid was used to 
transcribe mRNA ${ }^{\text {klc2-eGFP }}$ coding for KLC2 fused to eGFP. Plasmid without klc2 insert was used to transcribe $\mathrm{mRNA}^{\text {eGFP }}$ as a control. For $\mathrm{mRNA}^{\text {klc2-eGFP }}$ and $\mathrm{mRNA}^{\text {eGFP }}$ transcription, plasmids were linearized by NotI and the SP6 promoter was used for in vitro transcription using mMESSAGE MMACHINE® Kit (Ambion, Applied Biosystems). The mRNA ${ }^{\text {klc2-eGFP }}$ was used to perform the overexpression assay and for rescue of morphant's phenotype.

\section{Knockdown and overexpression assays}

Microinjection of morpholino oligonucleotides (MO) in the yolk of embryos at one- to two-cell stage were performed in specific concentrations (4 and $6 \mathrm{ng}$ ). Translation blocking morpholino (MO ${ }^{\text {klc2-TB }}$ ) sequence was 5'-GGTGGACATCACCCACTGACACACA-3' (misMo ${ }^{\text {klc2-TB }}$ was 5'-GGaGcACATgACCCAgTcACACACA-3') and splicing blocking morpholino ( $\mathrm{MO}^{\text {klc2-SP }}$ ) sequence was $5^{\prime}$-CGTGT GTGTTTCACCTGTGCTTCCC-3' (misMO ${ }^{\text {klc2-SP }}$ was $5^{\prime}$-CGTCTCT GTTTgACCTCTCCTTCCC-3'). MO ${ }^{\text {klc2-SP }}$ target exon 2 of klc2 gene. The rescue of phenotype was performed by co-injecting $6 \mathrm{ng}$ $\mathrm{MO}^{\text {klc2-SP }}$ and $100 \mathrm{pg} \mathrm{mRNA}^{\text {klc2-eGFP }}$ in the yolk of embryos staged at one- to two-cells. Chi-square and Fisher's exact tests were performed using GraphPad Prism version 5.00 (San Diego, CA, USA).

Overxpression of klc2 gene in zebrafish was performed by microinjecting $m R N A^{\text {klc2-eGFP }}$ at specific concentrations (100, 150 and $200 \mathrm{pg}$ ), as described in previous study (53). Same concentrations of mRNA ${ }^{\text {eGFP }}$ were microinjected in zebrafish embryos to be used as controls. Both microinjected embryos (mRNA ${ }^{\text {klc2-eGFP }}$ and mRNA $^{\text {eGFP }}$ ) were selected by fluorescence at 24 -hpf stage and evaluated at 48-hpf under MVX10 Olympus Microscope, and recorded with MVXTV1XC Olympus digital camera. Chi-square test was performed using GraphPad Prism version 5.00 (San Diego, CA, USA).

\section{Supplementary Material}

Supplementary Material is available at HMG online.

\section{Acknowledgements}

We are grateful to $\mathrm{H}$. Miranda for her help in conducting MN differentiation. We also thank R. Moura for his contribution in bioinformatics analysis.

Conflict of Interest statement. None declared.

\section{Funding}

This work was supported by Propesq/UEPB, PPSUS/FAPESQ/PB, Coordenação de Aperfeiçoamento de Pessoal de Nível Superior (CAPES), Instituto Nacional de Ciência e Tecnologia (INCT), Fundação de Amparo à Pesquisa do Estado de São Paulo (FAPESP)/ Centro de Pesquisa, Inovação e Difusão (CEPID) and National Counsel of Technological and Scientific Development (CNPq).

\section{References}

1. Lo Giudice, T., Lombardi, F., Santorelli, F.M., Kawarai, T. and Orlacchio, A. (2014) Hereditary spastic paraplegia: clinicalgenetic characteristics and evolving molecular mechanisms. Exp. Neurol. Nou., 261, 518-539.

2. Macedo-Souza, L., Kok, F., Santos, S., Amorim, S.C., Starling, A., Nishimura, A., Lezirovitz, K., Lino, A.M. and Zatz, M. (2005) Spastic paraplegia, optic atrophy, and neuropathy is linked to chromosome 11q13. Ann. Neurol., 57, 730-737.
3. Macedo-Souza, L., Kok, F., Santos, S., Licinio, L., Lezirovitz, K., Cavaçana, N., Bueno, C., Amorim, S., Pessoa, A., Graciani, Z. et al. (2009) Spastic paraplegia, optic atrophy, and neuropathy: new observations, locus refinement, and exclusion of candidate genes. Ann. Hum. Genet., 73, 382-387.

4. Windpassinger, C., Auer-Grumbach, M., Irobi, J., Patel, H., Petek, E., Hörl, G., Malli, R., Reed, J.A., Dierick, I., Verpoorten, N. et al. (2004) Heterozygous missense mutations in BSCL2 are associated with distal hereditary motor neuropathy and Silver syndrome. Nat. Genet., 36, 271-276.

5. Novarino, G., Fenstermaker, A.G., Zaki, M.S., Hofree, M., Silhavy, J.L., Heiberg, A.D., Abdellateef, M., Rosti, B., Scott, E., Mansour, L. et al. (2014) Exome sequencing links corticospinal motor neuron disease to common neurodegenerative disorders. Science, 31, 506-511.

6. Vale, R.D. (2003) The molecular motor toolbox for intracellular transport. Cell, 112, 467-480.

7. Hirokawa, N., Noda, Y., Tanaka, Y. and Niwa, S. (2009) Kinesin superfamily motor proteins and intracellular transport. Nat. Reu. Mol. Cell Biol., 10, 682-696.

8. Visscher, K., Schnitzer, M.J. and Block, S.M. (1999) Single kinesin molecules studied with a molecular force clamp. Nature, 400, 184-189.

9. Verhey, K.J. and Hammond, J.W. (2009) Traffic control: regulation of kinesin motors. Nat. Rev. Mol. Cell Biol., 10, 765-777.

10. Hirokawa, N., Niwa, S. and Tanaka, Y. (2010) Molecular motors in neurons: transport mechanisms and roles in brain function, development, and disease. Neuron, 68, 610-638.

11. Pernigo, S., Lamprecht, A., Steiner, R.A. and Dodding, M.P. (2013) Structural basis for kinesin-1: cargo recognition. Science, 340, 356-359.

12. Rahman, A., Friedman, D.S. and Goldstein, L.S.B. (1998) Two kinesin light chain genes in mice: identification and characterization of the encoded proteins. J. Biol. Chem., 273, 1539515403.

13. Perlson, E., Maday, S., Fu, M.M., Moughamian, A.J. and Holzbaur, E.L. (2010) Retrograde axonal transport: pathways to cell death? Trends Neurosci., 33, 335.

14. Millecamps, S. and Julien, J.P. (2013) Axonal transport deficits and neurodegenerative diseases. Nat. Reu. Neurosci., 14, 161176.

15. Reid, E., Kloos, M., Ashley-Koch, A., Hughes, L., Bevan, S., Svenson, I.K., Graham, F.L., Gaskell, P.C., Dearlove, A., Pericak-Vance, M.A. et al. (2002) A kinesin heavy chain (KIF5A) mutation in hereditary spastic paraplegia (SPG10). Am. J. Hum. Genet., 71, 1189-1194.

16. Ebbing, B., Mann, K., Starosta, A., Jaud, J., Schöls, L., Schüle, R. and Woehlke, G. (2008) Effect of spastic paraplegia mutations in KIF5A kinesin on transport activity. Hum. Mol. Genet., 17, 1245-1252.

17. Caballero Oteyza, A., Battaloğlu, E., Ocek, L., Lindig, T., Reichbauer, J., Rebelo, A.P., Gonzalez, M.A., Zorlu, Y., Ozes, B., Timmann, D. et al. (2014) Motor protein mutations cause a new form of hereditary spastic paraplegia. Neurology, 3 , 2007-2016.

18. Lee, J., Srour, M., Kim, D., Hamdan, F.F., Lim, S.H., BrunelGuitton, C., Décarie, J.C., Rossignol, E., Mitchell, G.A., Schreiber, A. et al. (2015) De novo mutations in the motor domain of KIF1A cause cognitive impairment, spastic paraparesis, axonal neuropathy and cerebellar atrophy. Hum. Mutat., 36, 69-78.

19. Munch, C., Rosenbohm, A., Sperfeld, A.D., Uttner, I., Reske, S., Krause, B.J., Sedlmeier, R., Meyer, T., Hanemann, C.O., Stumm, G. et al. (2005) Heterozygous R1101K mutation of 
the DCTN1 gene in a family with ALS and FTD. Ann. Neurol., $58,777$.

20. Falzone, T.L., Stokin, G.B., Lillo, C., Rodrigues, E.M., Westerman, E.L., Williams, D.S. and Goldstein, L.S. (2009) Axonal stress kinase activation and tau misbehavior induced by kinesin-1 transport defects. J. Neurosci., 29, 5758.

21. Füger, P., Sreekumar, V., Schüle, R., Kern, J.V., Stanchev, D.T., Schneider, C.D., Karle, K.N., Daub, K.J., Siegert, V.K., Flötenmeyer, M. et al. (2012) Spastic paraplegia mutation N256S in the neuronal microtubule motor KIF5A disrupts axonal transport in a Drosophila HSP model. PLoS Genet., 8, e1003066.

22. Valdmanis, P.N., Meijer, I.A., Reynolds, A., Lei, A., MacLeod, P., Schlesinger, D., Zatz, M., Reid, E., Dion, P.A., Drapeau, P. et al. (2007) Mutations in the KIAA0196 gene at the SPG8 locus cause hereditary spastic paraplegia. Am. J. Hum. Genet., 80, 152-161.

23. Lin, P., Li, J., Liu, Q., Mao, F., Li, J., Qiu, R., Hu, H., Song, Y., Yang, Y., Gao, G. et al. (2008) A missense mutation in SLC33A1, which encodes the acetyl-CoA transporter, causes autosomal-dominant spastic paraplegia (SPG42). Am. J. Hum. Genet., 83, 752-759.

24. Clemen, C.S., Tangavelou, K., Strucksberg, K.H., Just, S., Gaertner, L., Regus-Leidig, H., Stumpf, M., Reimann, J., Coras, R., Morgan, R.O. et al. (2010) Strumpellin is a novel valosin-containing protein binding partner linking hereditary spastic paraplegia to protein aggregation diseases. Brain, 133, 2920-2941.

25. Fassier, C., Hutt, J.A., Scholpp, S., Lumsden, A., Giros, B., Nothias, F., Schneider-Maunoury, S., Houart, C. and Hazan, J. (2010) Zebrafish atlastin controls motility and spinal motor axon architecture via inhibition of the BMP pathway. Nat. Neurosci., 13, 1380-1387.

26. Martin, E., Yanicostas, C., Rastetter, A., Naini, S.M., Maouedj, A., Kabashi, E., Rivaud-Péchoux, S., Brice, A., Stevanin, G. and Soussi-Yanicostas, N. (2012) Spatacsin and spastizin act in the same pathway required for proper spinal motor neuron axon outgrowth in zebrafish. Neurobiol. Dis., 48, 299-308.

27. Martin, E., Schüle, R., Smets, K., Rastetter, A., Boukhris, A., Loureiro, J.L., Gonzalez, M.A., Mundwiller, E., Deconinck, T., Wessner, M. et al. (2013) Loss of function of glucocerebrosidase GBA2 is responsible for motor neuron defects in hereditary spastic paraplegia. Am. J. Hum. Genet., 92, 238-244.

28. Song, Y., Wang, M., Mao, F., Shao, M., Zhao, B., Song, Z., Shao, C. and Gong, Y. (2013) Knockdown of Pnpla6 protein results in motor neuron defects in zebrafish. Dis. Model Mech., 6, 404-413.

29. Cremers, F.P.M., Pfeiffer, R.A., van de Pol, T.J., Hofker, M.H., Kruse, T.A., Wieringa, B. and Ropers, H.H. (1987) An interstitial duplication of the $\mathrm{X}$ chromosome in a male allows physical fine mapping of probes from the Xq13-q22 region. Hum. Genet., 77, 23-27.

30. Hodes, M.E., Pratt, V.M. and Dlouhy, S.R. (1993) Genetics of Pelizaeus-Merzbacher disease. Dev. Neurosci., 15, 383-394.

31. Inoue, K., Osaka, H., Sugiyama, N., Kawanishi, C., Onishi, H., Nezu, A., Kimura, K., Yamada, Y. and Kosaka, K. (1996) A duplicated PLP gene causing Pelizaeus-Merzbacher disease detected by comparative multiplex PCR. Am. J. Hum. Genet., 59, 32-39.

32. Mimault, C., Giraud, G., Courtois, V., Cailloux, F., Boire, J.Y., Dastugue, B. and Boespflug-Tanguy, O. (1999) Clinical European network on brain dysmyelinating disease. Proteolipoprotein gene analysis in 82 patients with sporadic Pelizaeus-Merzbacher disease: duplications, the major cause of the disease, originate more frequently in male germ cells, but point mutations do not. Am. J. Hum. Genet., 65, 360-369.

33. Carvalho, C.M.B., Ramocki, M.B., Pehlivan, D., Franco, L.M., Gonzaga-Jauregui, C., Fang, P., McCall, A., Pivnick, E.K., Hines-Dowell, S., Seaver, L.H. et al. (2011) Inverted genomic segments and complex triplication rearrangements are mediated by inverted repeats in the human genome. Nat. Genet., 43, 1074-1081.

34. Hertz, J.M., Borglum, A.D., Brandt, C.A., Flint, T. and Bisgaard, C. (1994) Charcot-Marie-Tooth disease type 1A: the parental origin of a de novo 17p11.2-p12 duplication. Clin. Genet., 46, 291-294.

35. Sorour, E., Thompson, P., MacMillan, J. and Upadhyaya, M. (1995) Inheritance of CMT1A duplication from a mosaic father. J. Med. Genet., 32, 483-485.

36. Theuns, J., Brouwers, N., Engelborghs, S., Sleegers, K., Bogaerts, V., Corsmit, E., De Pooter, T., van Duijn, C.M., De Deyn, P.P. and Van Broeckhoven, C. (2006) Promoter mutations that increase amyloid precursor-protein expression are associated with Alzheimer disease. Am. J. Hum. Genet., 78, 936-946.

37. Nagaraj, K., Kristiansen, L.V., Skrzynski, A., Castiella, C., GarciaAlonso, L. and Hortsch, M. (2009) Pathogenic human L1-CAM mutations reduce the adhesion-dependent activation of EGFR. Hum. Mol. Genet., 18, 3822-3831.

38. Meijer, I.A., Dion, P., Laurent, S., Dupré, N., Brais, B., Levert, A., Puymirat, J., Rioux, M.F., Sylvain, M., Zhu, P.P. et al. (2007) Characterization of a novel SPG3A deletion in a French-Canadian family. Ann. Neurol., 61, 599-603.

39. Havlicek, S., Kohl, Z., Mishra, H.K., Prots, I., Eberhardt, E., Denguir, N., Wend, H., Plötz, S., Boyer, L., Marchetto, M.C. et al. (2014) Gene dosage-dependent rescue of HSP neurite defects in SPG4 patients' neurons. Hum. Mol. Genet., 15, 2527-2541.

40. Bakowska, J.C., Wang, H., Xin, B., Sumner, C.J. and Blackstone, C. (2008) Lack of spartin protein in Troyer syndrome: a loss-offunction disease mechanism? Arch. Neurol., 65, 520-524.

41. Kruer, M.C., Paisán-Ruiz, C., Boddaert, N., Yoon, M.Y., Hama, H., Gregory, A., Malandrini, A., Woltjer, R.L., Munnich, A., Gobin, S. et al. (2010) Defective FA2H leads to a novel form of neurodegeneration with brain iron accumulation (NBIA). Ann. Neurol., 68, 611-618.

42. Li, H. and Durbin, R. (2010) Fast and accurate long-read alignment with Burrows-Wheeler transform. Bioinformatics, 26, 589-595.

43. McKenna, A., Hanna, M., Banks, E., Sivachenko, A., Cibulskis, K., Kernytsky, A., Garimella, K., Altshuler, D., Gabriel, S., Daly, M. et al. (2010) The Genome Analysis Toolkit: a MapReduce framework for analyzing next-generation DNA sequencing data. Genome Res., 20, 1297-1303.

44. Wang, K., Li, M. and Hakonarson, H. (2010) ANNOVAR: Functional annotation of genetic variants from next-generation sequencing data. Nucleic Acids Res., 38, e164.

45. Plagnol, V., Curtis, J., Epstein, M., Mok, K.Y., Stebbings, E., Grigoriadou, S., Wood, N.W., Hambleton, S., Burns, S.O., Thrasher, A.J. et al. (2012) A robust model for read count data in exome sequencing experiments and implications for copy number variant calling. Bioinformatics, 28, 2747-2754.

46. Cingolani, P., Platts, A., Wang le, L., Coon, M., Nguyen, T., Wang, L., Land, S.J., Lu, X. and Ruden, D.M. (2012) A program for annotating and predicting the effects of single nucleotide polymorphisms, SnpEff: SNPs in the genome of Drosophila melanogaster strain w1118; iso-2; iso-3. Fly, 6, 80-92.

47. Marchetto, M.C., Carromeu, C., Acab, A., Yu, D., Yeo, G.W., Mu, Y., Chen, G., Gage, F.H. and Muotri, A.R. (2010) A model for 
neural development and treatment of Rett syndrome using human induced pluripotent stem cells. Cell, 12, 527-539.

48. Mitne-Neto, M., Machado-Costa, M., Marchetto, M.C., Bengtson, M.H., Joazeiro, C.A., Tsuda, H., Bellen, H.J., Silva, H.C., Oliveira, A.S., Lazar, M. et al. (2011) Downregulation of VAPB expression in motor neurons derived from induced pluripotent stem cells of ALS8 patients. Hum. Mol. Genet., 15, 36423652.

49. Irizarry, R.A., Hobbs, B., Collin, F., Beazer-Barclay, Y.D., Antonellis, K.J., Scherf, U. and Speed, T.P. (2003) Exploration, normalization, and summaries of high density oligonucleotide array probe level data. Biostatistics, 4, 249-264.

50. Schmittgen, T.D. and Livak, K.J. (2008) Analyzing real-time PCR data by the comparative C(T) method. Nat. Protoc., 3, 1101-1108.
51. Soltys, D.T., Rocha, C.R., Lerner, L.K., de Souza, T.A., Munford, V., Cabral, F., Nardo, T., Stefanini, M., Sarasin, A., Cabral-Neto, J.B. et al. (2013) Novel XPG (ERCC5) mutations affect DNA repair and cell survival after ultraviolet but not oxidative stress. Hum. Mutat., 34, 481-489.

52. Favaro, F.P., Alvizi, L., Zechi-Ceide, R.M., Bertola, D., Felix, T.M., de Souza, J., Raskin, S., Twigg, S.R., Weiner, A.M., Armas, P. et al. (2014) A noncoding expansion in EIF4A3 causes Richieri-Costa-Pereira syndrome, a craniofacial disorder associated with limb defects. Am. J. Hum. Genet., 94, 120-128.

53. Niederriter, A., Davis, E.E., Golzio, C., Oh, E.C., Tsai, I.C. and Katsanis, N. (2013) In vivo modeling of the morbid human genome using Danio rerio. J. Vis. Exp., 24, e50338. 


\section{Human Molecular Genetics}

\section{Supplemental material}

Overexpression of $K L C 2$ due to a homozygous deletion in the non-coding region causes SPOAN syndrome

Uirá S. Melo, Lucia I. Macedo-Souza, Thalita Figueiredo, Alysson R. Muotri, Joseph G. Gleeson, Gabriela Coux, Pablo Armas, Nora B. Calcaterra, João P. Kitajima, Simone Amorim, Thiago R.

Olávio, Karina Griesi-Oliveira, Giuliana C. Coatti, Clarissa R.R. Rocha, Marinalva MartinsPinheiro, Carlos F.M. Menck, Maha S. Zaki, Fernando Kok, Mayana Zatz, Silvana Santos. 

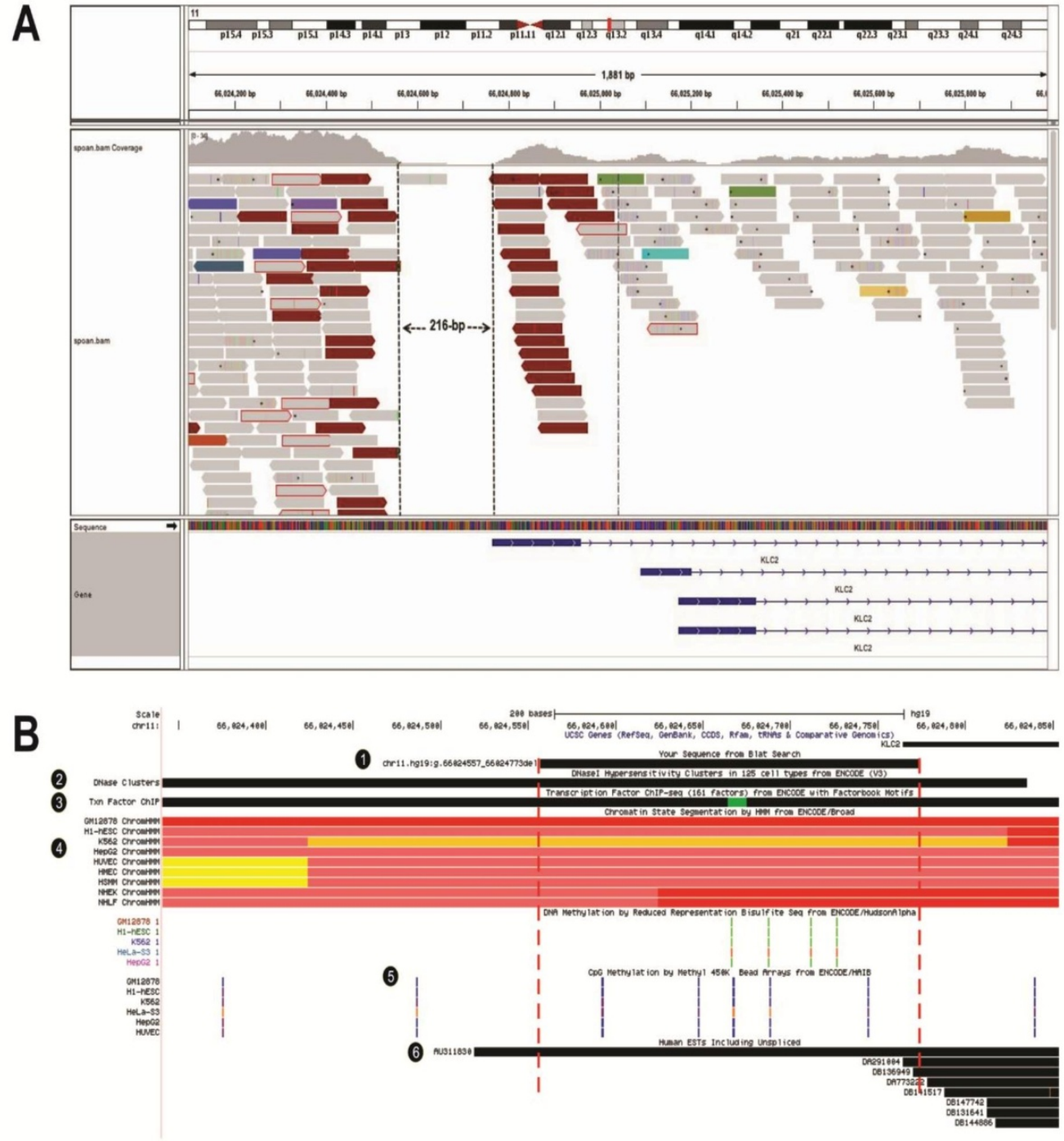

Figure S1. (A) BAM file of WGS result from one SPOAN patients showing the alignment of $K L C 2$ upstream region, highlighting the 216-bp deletion, visualized in IGV 2.3 software (Broad institute). (B) Screenshot retrieved from UCSC genome browser showing $K L C 2$ upstream region, highlighting the 216-bp deletion (sorrounded by red dashed lines). Numbers inside black circles means: 1- SPOAN mutation (216-bp deletion); 2- DHS; 3- TFBS; 4- Chromatin state segmentation by HMM, in which yellow/orange bars means that region probably acts as enhancer (Ernst et al., 2011); 5- DNA methylation; 6- IncRNA (AU311830.1) 
A

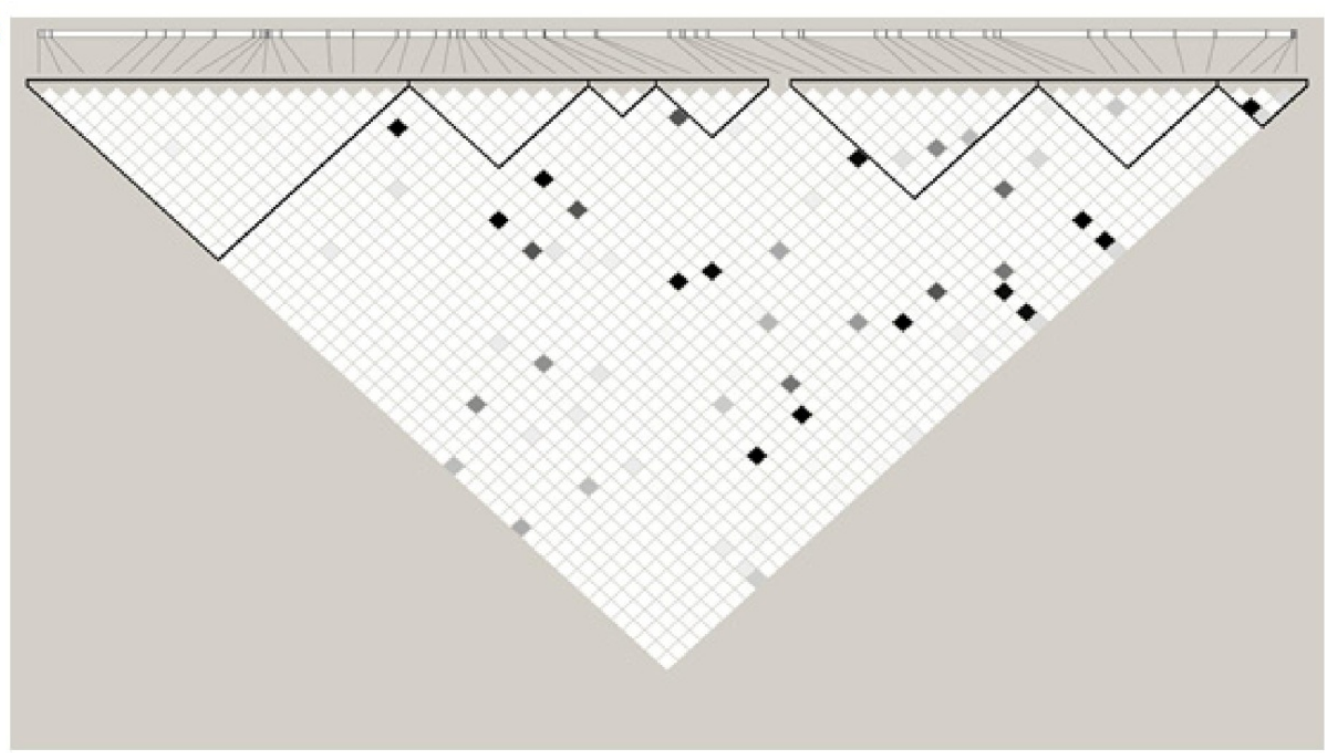

B

Average Fst - KLC2

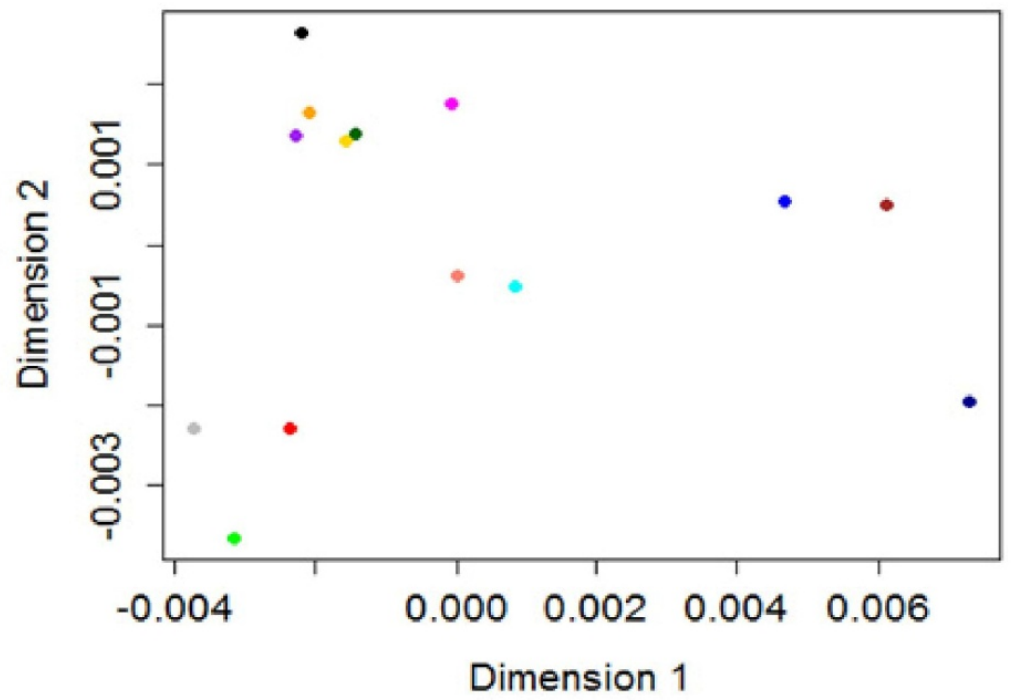

Figure S2 (A) Linkage disequilibrium blocks between $10 \mathrm{~kb}$ up- and downstream of $K L C 2$. Darkest blocks suggest strong LD between markers. (B) MDS plot of PCA based on FST. Distant plots mean higher genetic diversity among populations. 


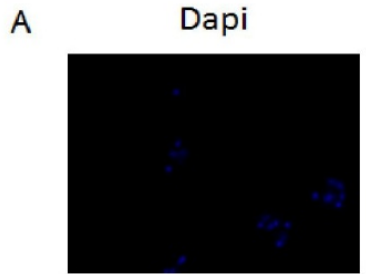

Dapi

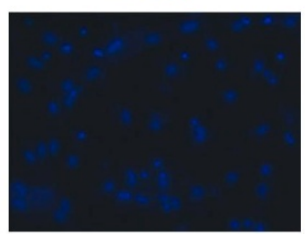

B

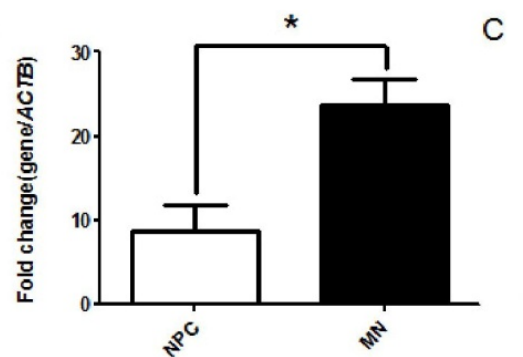

$\mathrm{Hb9}$

C
$\mathrm{Hb9}$
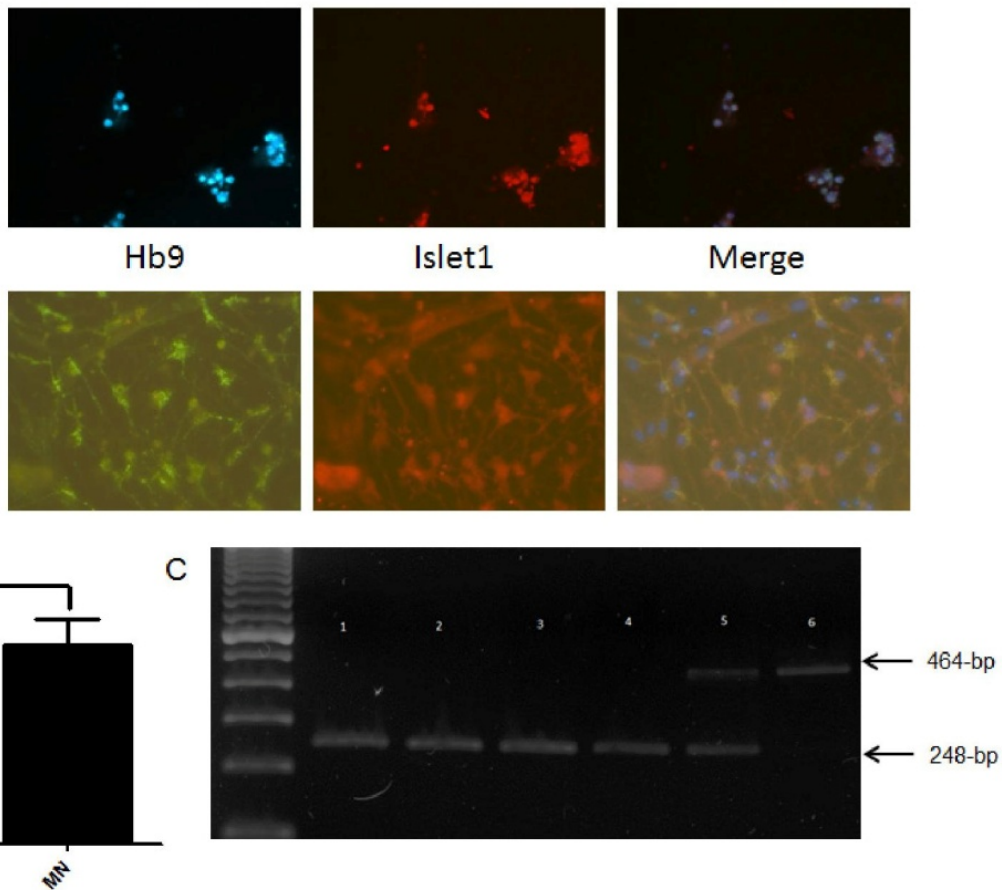

Figure S3 (A) Immunofluorescence using neurons and MN markers. First row shows one heterozygote MN sample and second row shows MN healthy control sample. Original magnification 400X. (B) Relative expression of CHAT measured by qRT-PCR performed in NPC and MN ( $p$-value <0.05). (C) PCR product showing 216-bp deletion visualized in agarose gel (2\%): (1) DNA extracted from blood of affected individual. (2-4) DNA extracted from MN showing 216-bp deletion in homozygosis, (5) in heterozygosis and (6) in wild-type. 
Table S1 Variants detected in WES using GRCh37 as genomic reference and checked for co-segregation using Sanger sequencing.

\begin{tabular}{|c|c|c|c|c|c|c|c|c|c|c|c|c|c|}
\hline \multirow{2}{*}{ Gene } & \multirow{2}{*}{ Variant } & \multirow{2}{*}{$\begin{array}{c}\text { Gene } \\
\text { location }\end{array}$} & \multirow{2}{*}{$\begin{array}{c}\text { Allele } \\
\text { Frequency* }\end{array}$} & \multicolumn{3}{|c|}{ Patients } & \multicolumn{3}{|c|}{$\begin{array}{c}\text { Family } \\
\text { controls }\end{array}$} & \multicolumn{3}{|c|}{$\begin{array}{c}\text { Unrelated } \\
\text { controls } \\
\end{array}$} & \multirow{2}{*}{$\begin{array}{l}\text { Excluded } \\
\text { as } \\
\text { candidate? }\end{array}$} \\
\hline & & & & $-/-$ & $+/-$ & $+/+$ & $-1-$ & $+/-$ & $+/+$ & $-/-$ & $+/-$ & $+/+$ & \\
\hline CLCF1 & $67,135,092 \mathrm{~A}>\mathrm{G}$ & Exon 2 & $8.453 e-06$ & 48 & 0 & 0 & 18 & 0 & 62 & NP & NP & NP & Yes \\
\hline RIN1 & $66,102,179 A>C$ & Exon 5 & 0.002141 & 0 & 0 & 20 & NP & NP & NP & NP & NP & NP & Yes \\
\hline MRPL11 & $66,205,845 \mathrm{C}>\mathrm{T}$ & NCR & NA & 71 & 0 & 0 & 0 & 46 & 23 & 0 & 0 & 140 & No \\
\hline ACTN3 & $66,326,677 \mathrm{G}>A$ & NCR & 0.001239 & 65 & 0 & 0 & 0 & 40 & 20 & 7 & 40 & 95 & Yes \\
\hline RBM4B & $66,444,626 \mathrm{G}>\mathrm{A}$ & NCR & $\mathrm{NA}$ & 71 & 0 & 0 & 0 & 47 & 23 & 0 & 46 & 169 & No \\
\hline NUDT8 & $67,396,600 \mathrm{G}>\mathrm{C}$ & NCR & NA & 29 & 1 & 0 & NP & NP & NP & 8 & 61 & 24 & Yes \\
\hline
\end{tabular}

Table key: NCR - Non-coding region; NA - Not annotated; NP - Molecular test not performed; /-, +/- and +/+ means homozygote for mutated allele, heterozygote and homozygote for wild-type allele, respectively. *Allele frequency obtained from ExAC. 
Table S2 Genes with significant differential expression in SPOAN patients compared to controls.

\begin{tabular}{|c|c|c|c|}
\hline Gene & Fold Change & $p$-value & Chromosome region \\
\hline DPF2 & 1.022 & $1.09 \mathrm{E}-03$ & $11 \mathrm{q} 13.1$ \\
\hline CYB561A3 & 1.017 & $1.49 \mathrm{E}-03$ & $11 \mathrm{q} 12.2$ \\
\hline CCDC88B & 1.029 & $1.90 \mathrm{E}-03$ & $11 \mathrm{q} 12.3$ \\
\hline ATL3 & -1.038 & $2.05 \mathrm{E}-03$ & $11 \mathrm{q} 13.1$ \\
\hline AIP & 1.025 & $2.25 \mathrm{E}-03$ & $11 \mathrm{q} 13.3$ \\
\hline SCYL1 & 1.029 & $2.43 \mathrm{E}-03$ & $11 \mathrm{q} 13$ \\
\hline B3GAT3 & 1.09 & $2.56 \mathrm{E}-04$ & $11 \mathrm{q} 12.3$ \\
\hline MRPL11 & -1.083 & $2.94 \mathrm{E}-03$ & $11 \mathrm{q} 13.3$ \\
\hline FAM89B & 1.025 & $2.97 \mathrm{E}-03$ & $11 \mathrm{q} 13$ \\
\hline TMEM138 & 1.048 & $3.25 \mathrm{E}-03$ & $11 \mathrm{q} 12.2$ \\
\hline STX5 & 1.102 & $3.41 \mathrm{E}-03$ & $11 \mathrm{q} 12.3$ \\
\hline ZFPL1 & 1.071 & $3.43 \mathrm{E}-03$ & $11 \mathrm{q} 13$ \\
\hline CAPN1 & 1.046 & $3.55 \mathrm{E}-03$ & $11 \mathrm{q} 13$ \\
\hline$S N X 32$ & 1.111 & $3.88 \mathrm{E}-03$ & $11 \mathrm{q} 13.1$ \\
\hline EFEMP2 & 1.024 & $4.36 \mathrm{E}-03$ & $11 \mathrm{q} 13.1$ \\
\hline MARK2 & 1.057 & $4.53 \mathrm{E}-03$ & $11 \mathrm{q} 13.1$ \\
\hline RAD9A & 1.03 & $4.99 \mathrm{E}-03$ & $11 \mathrm{q} 13.1-\mathrm{q} 13.2$ \\
\hline SSH3 & 1.078 & $6.09 \mathrm{E}-03$ & $11 \mathrm{q} 13.2$ \\
\hline ATG2A & 1.073 & $6.77 \mathrm{E}-03$ & $11 \mathrm{q} 13.1$ \\
\hline SUV42OH1 & -1.041 & $7.15 \mathrm{E}-03$ & $11 \mathrm{q} 13.2$ \\
\hline FOLH1 & 1.028 & $9.04 \mathrm{E}-03$ & $11 \mathrm{p} 11.2$ \\
\hline FKBP2 & -1.02 & $9.04 \mathrm{E}-03$ & $11 \mathrm{q} 13.1-\mathrm{q} 13.3$ \\
\hline KLC2 & 1.068 & $9.21 \mathrm{E}-04$ & $11 \mathrm{q} 13.2$ \\
\hline
\end{tabular}


Table S3 Primers sequences used in this study.

\begin{tabular}{|c|c|c|c|c|}
\hline Primer ID & Sense & Primers sequencing $\left(5^{\prime}-3^{\prime}\right)$ & Target region & Purpose \\
\hline \multirow{2}{*}{1} & Forward & GCCCTGGGTTCATTGACTTA & \multirow{2}{*}{$\begin{array}{l}\text { KLC2 upstream } \\
\text { region }\end{array}$} & \multirow{2}{*}{$\begin{array}{l}\text { Detect 216-bp deletion amplification } \\
\text { by PCR }\end{array}$} \\
\hline & Reverse & ACCCAGACGGACAAGCTAGA & & \\
\hline \multirow{2}{*}{2} & Forward & CACTGGATGACCTGTTCCCC & \multirow{2}{*}{$\begin{array}{l}\text { KLC2 exon } \\
\text { boundaries (3-4) }\end{array}$} & \multirow{2}{*}{$\begin{array}{l}\text { Evaluate } K L C 2 \text { expression in } \\
\text { SPOAN samples }\end{array}$} \\
\hline & Reverse & ATGCTGACCAGACACATCCC & & \\
\hline 3 & Reverse & CAACAGCACTTTCCCCACG & $\begin{array}{l}\text { 3'UTR of zebrafish } \\
\text { KIc2 }\end{array}$ & $\begin{array}{l}\text { Reverse transcription of } k / c 2 \text { in } \\
\text { zebrafish }\end{array}$ \\
\hline \multirow{2}{*}{4} & Forward & GGGGAATTCAATGTCCACCATGGTTTACCCTC & \multirow[t]{2}{*}{ Whole $k l c 2$} & \multirow{2}{*}{$\begin{array}{l}\text { Microinjection in zebrafish embryos } \\
\text { for } k l c 2 \text { overexpression assay }\end{array}$} \\
\hline & Reverse & CCCGAGCTCACACTGATCAGAGAGTTGCGTCT & & \\
\hline
\end{tabular}




\subsection{Resultados do experimento de WISH em zebrafish}

O experimento de WISH foi realizado com a finalidade de identificar o padrão de expressão espaço-temporal do klc2 em zebrafish, em quatro estágios embrionários diferentes: 4 a 8 células, 15 a 20 somitos, 48- e 72-hpf. Em embriões de 4 a 8 células observou-se um padrão de expressão significativo do $k l c 2$, o que se sugere expressão de origem materna desse gene (Figura 6a). No segundo estágio embrionário avaliado observou-se o padrão de expressão preferencial nos somitos (Figura 6b). A expressão do $k l c 2$ ficou mais definida em estágios embrionários mais avançados, apresentando um padrão específico de expressão na notocorda, retina, nervo ótico, prosencéfalo e em somitos, em embriões no estágio de 48-hpf e 72-hpf (Figura 7). Esse padrão de expressão do $k l c 2$ é similar ao detectado nos genes parálogos $k l c l a$ e $k l c 1 b$ por Thisse $\&$ Thisse (2004).

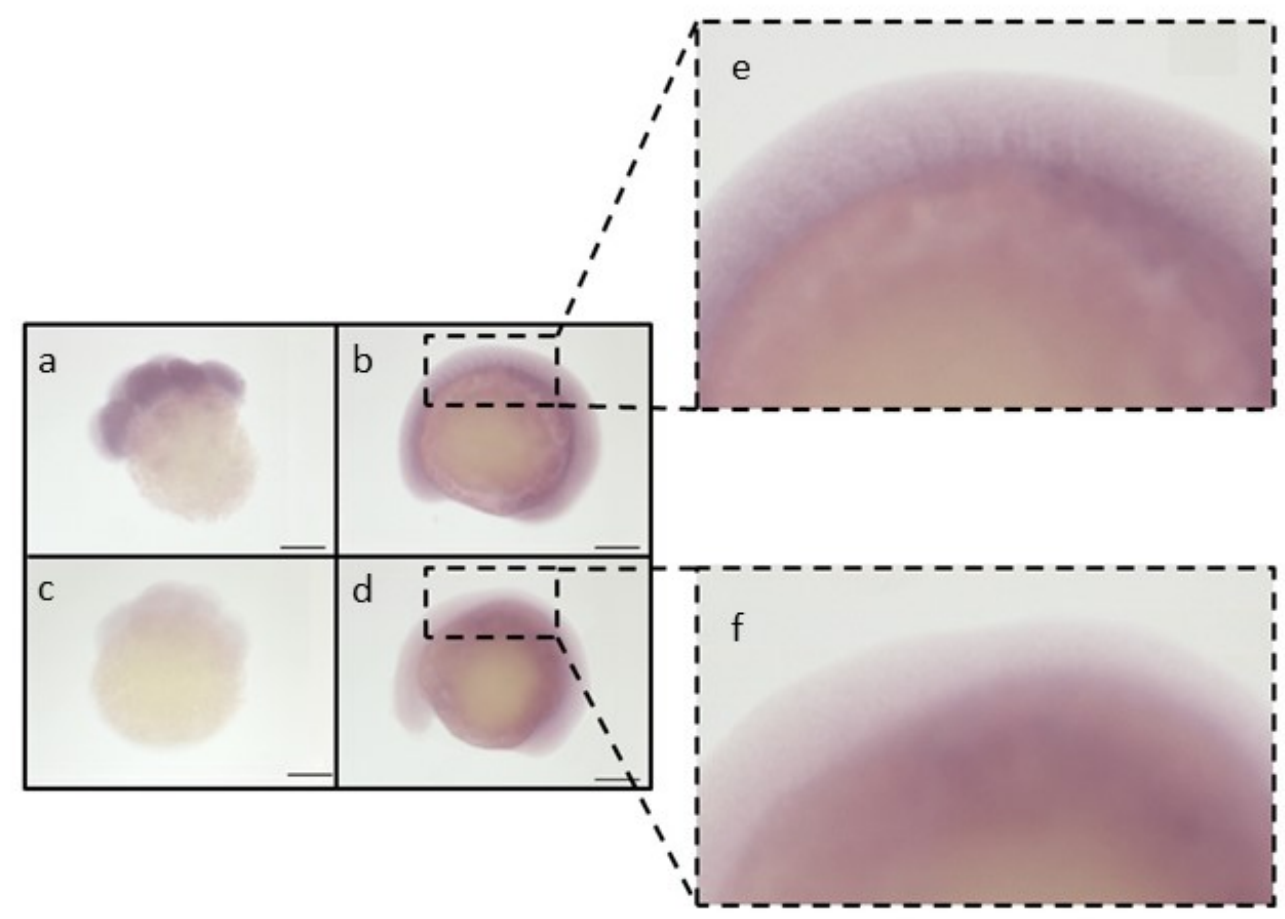


Figura 6. Padrão de expressão do $k l c 2$ por meio de WISH em embriões no estágio de 4 a 8 células $(\mathrm{a}, \mathrm{c})$ e embriões no estágio de 15 a 20 somitos (b,d,e,f). As imagens (c) (d) são controle negativo utilizando a sonda senso. Scale bar $500 \mu \mathrm{m}$.

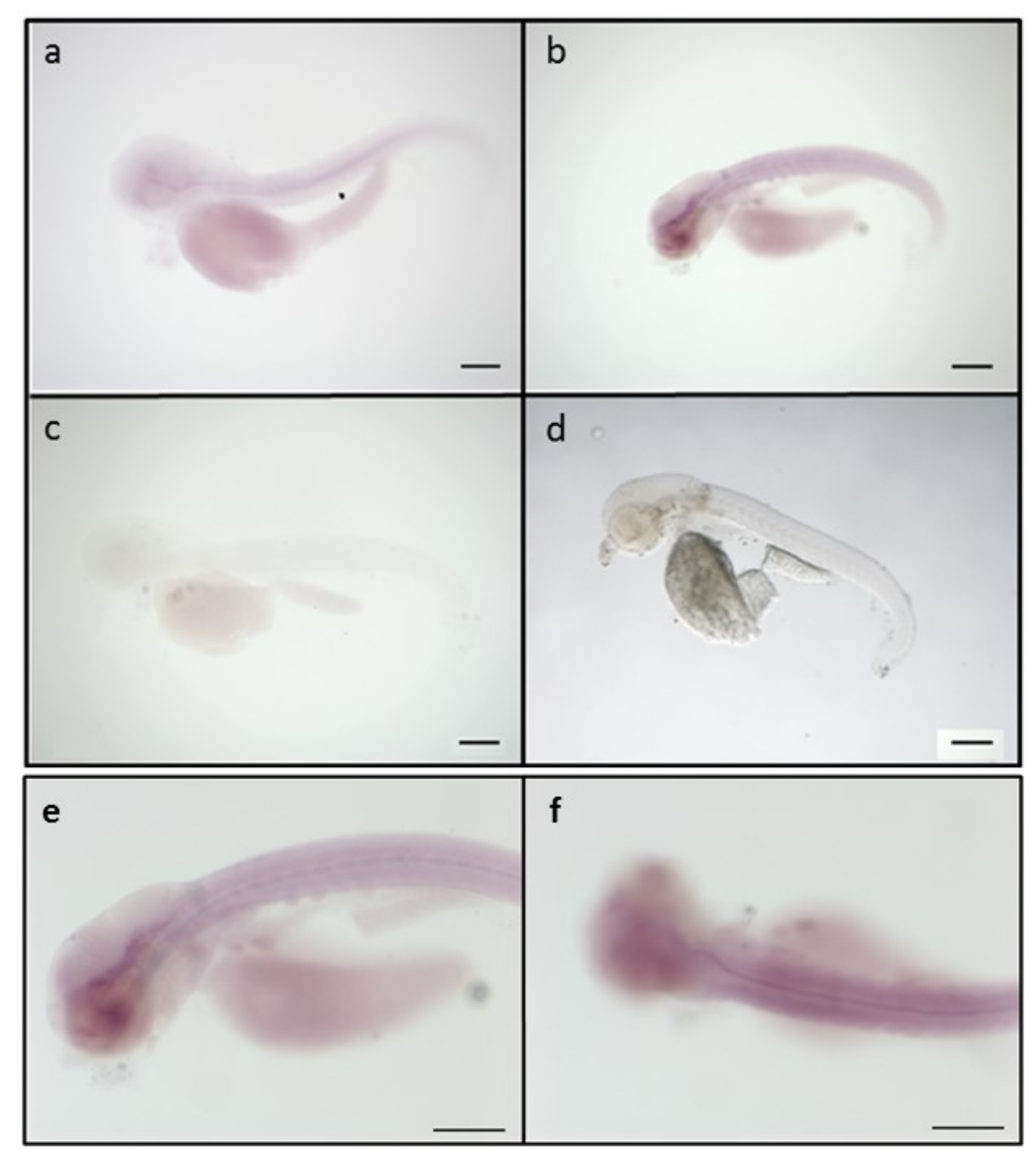

Figura 7. Padrão de expressão do $k l c 2$ por meio de WISH em embriões no estágio de 48-hpf (a,b,c,d) e embriões no estágio de 72-hpf (e,f). As imagens (c) e (d) são controle negativo utilizando a sonda senso em embriões no estágio de 48-hpf. Scale bar $500 \mu \mathrm{m}$.

\subsection{Ensaios realizados em modelo de camundongo}

Ainda dentro do tema da tese de doutorado, sugerimos a realização de outros estudos funcionais visando compreender melhor os mecanismos genéticos e a fisiopatologia da síndrome SPOAN. Durante o período de Março a Dezembro de 2015, foi realizado um estágio do 
doutorando no exterior (“doutorado-sanduíche”) no Lawrence Berkeley National Laboratory, situado na cidade de Berkeley, Estados Unidos, sob supervisão de Len Pennacchio, Ph.D. Nessa colaboração foi utilizado o camundongo como modelo animal da síndrome SPOAN.

Camundongos transgênicos para o KLC2 humano foram gerados durante essa colaboração. Estudos de qPCR e qRT-PCR confirmaram a inserção, número de cópias do transgene e a expressão do mRNA do KLC2 humano nos transgênicos. Estudos de gene reporter usando LacZ também foram realizados, nos quais as construções com a região regulatória wildtype e a com deleção de 216-pb foram microinjetados em embriões para visualizar o padrão de expressão do LacZ das duas diferentes construções.

\subsubsection{Resultados do gene reporter LacZ em embriões de camundongos}

Camundongos com o gene reporter para a região regulatória wild-type coletados no estágio de e.15.5

Embriões com a construção do gene reporter contendo a região regulatória wild-type do KLC2 humano foram coletados no estágio de e.15.5 para coloração por meio do gene reporter LacZ. Nós obtivemos 16 embriões com marcação positiva do gene reporter. Nesses embriões positivos, a expressão do LacZ foi levemente detectada nos rins e na coluna espinhal, além de que alguns embriões apresentaram expressão generalizada, ou seja, expressão não bem definida e sem reprodutividade (Figura 8). Embora tivemos um número significativo de embriões positivos para o LacZ, visto que acima de cinco embriões positivos é considerado válido para caracterizar o padrão de expressão da região regulatória alvo do ensaio, os resultados não foram reprodutíveis, o que nos sugere relatar que estudos utilizando a região regulatória wild-type do 
KLC2 humano foram inconclusivos para identificar o padrão de expressão espacial do gene reporter.
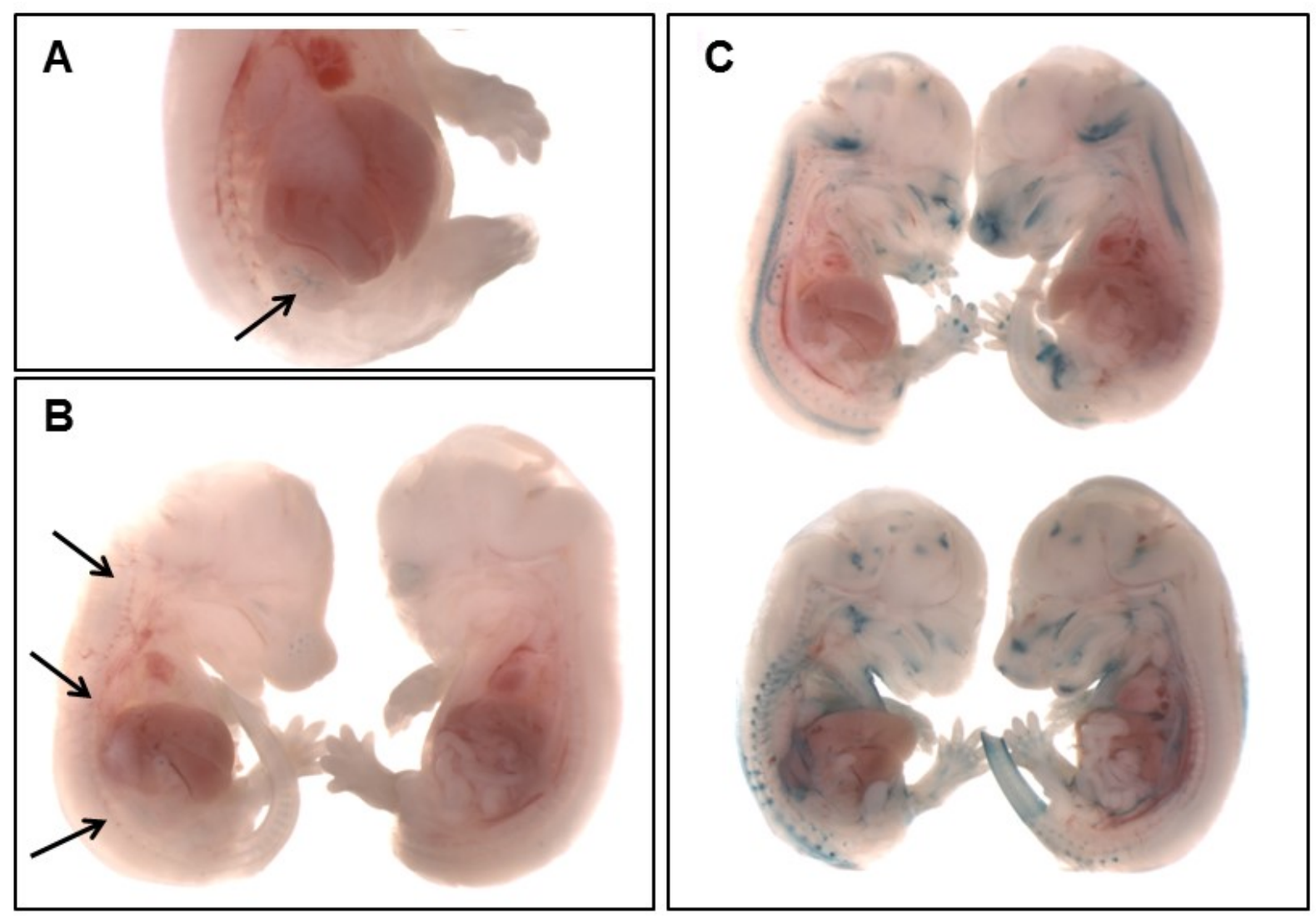

Figura 8. Expressão do LacZ em embriões no estágio e.15.5 usando a construção da região regulatória wild-type. (A) Expressão pouco expressiva no rim $(\mathrm{n}=9 / 16)$. (B) Expressão muito pouco expressiva na espinha $(n=3 / 16)$. (C) Expressão generalizada não bem definida $(n=2 / 16)$.

Camundongos com o gene reporter para a região regulatória com a deleção de 216pb coletados no estágio de e.15.5

Embriões com a construção do gene reporter contendo a região regulatória com a deleção de 216-pb do KLC2 humano foram coletados no estágio de e.15.5 para coloração por meio do gene reporter LacZ. Nós obtivemos oito embriões positivos para o gene reporter, sendo a expressão do LacZ detectada no rim, medula espinhal, narinas e expressão generalizada não bem 
definida (Figura 9). Embora um forte sinal de expressão do LacZ foi detectado na medula espinhal, o que seria relevante em relação ao fenótipo da síndrome SPOAN, os resultados não foram reprodutíveis e nós consideramos o resultado da expressão do gene reporter contendo a região regulatória com a deleção de 216-pb inconclusivos.

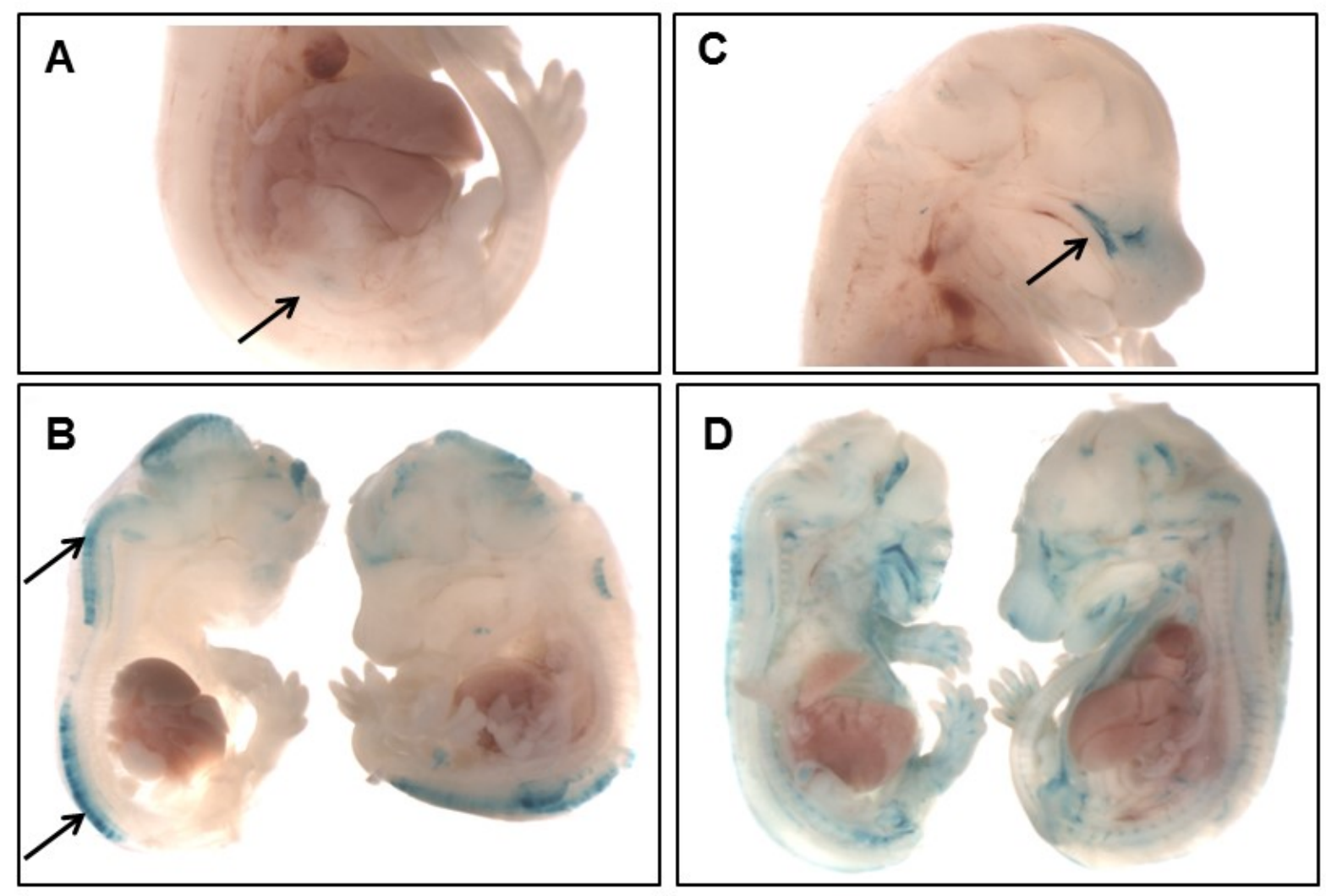

Figura 9. Expressão do LacZ em embriões no estágio e.15.5 usando a construção da região regulatória com a deleção de 216-pb. (A) Expressão com baixa intensidade no rim $(n=3 / 8)$. (B) Expressão com alta intensidade na medula espinhal $(n=1 / 8)$. (C) Expressão na região nasal $(n=2 / 8)$. (D) Expressão generalizada não bem definida $(n=2 / 8)$.

\subsubsection{Superexpressão do $K L C 2$ humano em camundongos}

Nós geramos camundongos transgênicos que continham o $K L C 2$ humano inserido no seu genoma por meio de microinjeções pronucleares do Fosmídeo do KLC2. Após a microinjeção nós obtivemos sete camundongos transgênicos $(\mathrm{n}=7 / 59,12 \%)$ contendo o $K L C 2$ humano. $\mathrm{O}$ 
comprimento da inserção do Fosmídeo do $K L C 2$ no genoma dos camundongos foi avaliado por meio de PCR usando primers para regiões específicas do Fosmídeo (ver Tabela 4 na seção 2.5.2 de materiais e métodos; Figura 10). Os camundongos transgênicos da primeira geração serão chamados a partir de agora de camundongos da geração F0.
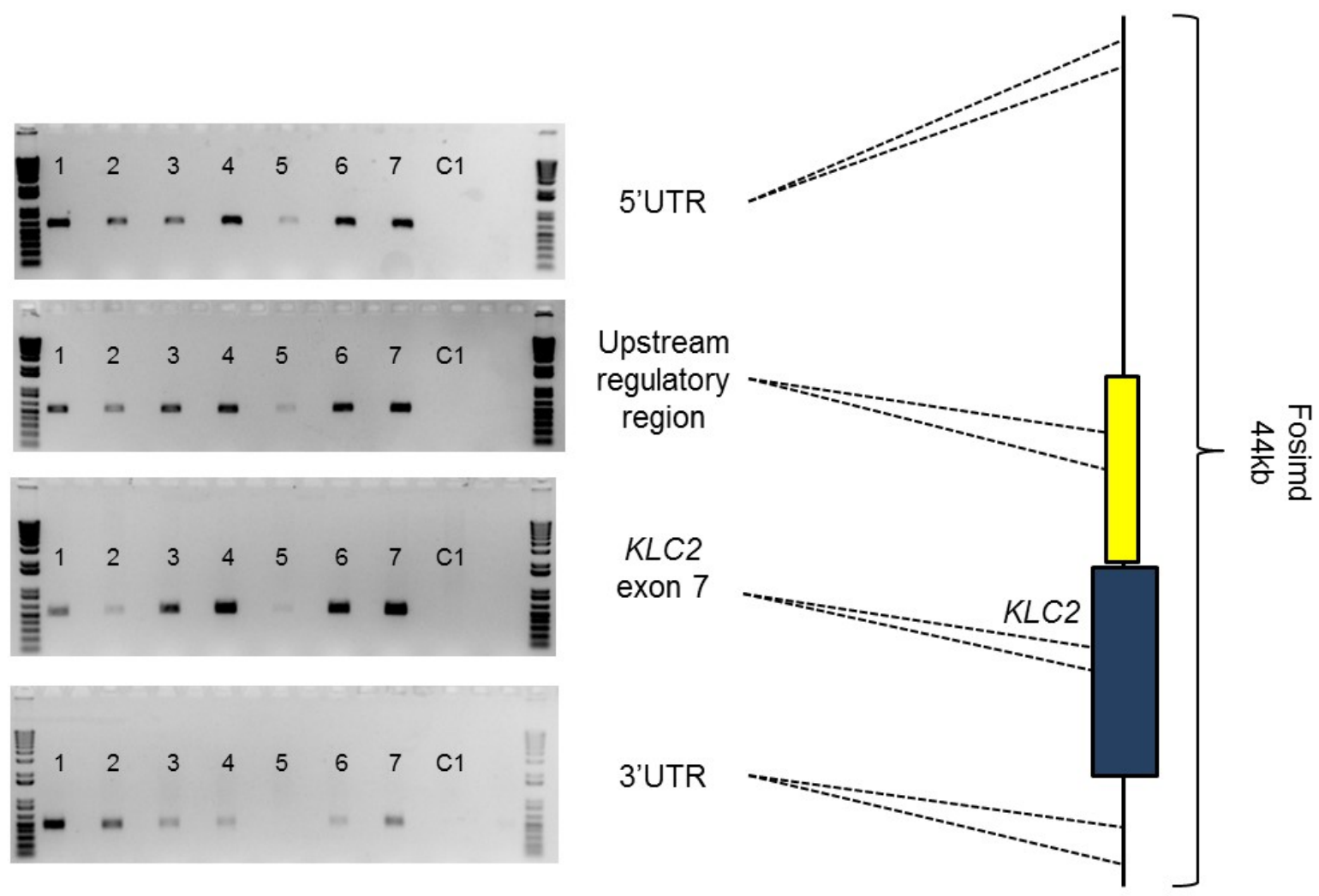

Figura 10. Esquematização da localização dos amplicons da PCR no Fosmídeo. Os produtos de PCR foram submetidos a eletroforese em gel de agarose para checar o comprimento do Fosmídeo do KLC2 inserido no genoma dos camundongos da geração F0. C1 é amostra de camundongo wild-type e foi utilizada como controle negativo.

\subsubsection{Camundongos da geração Fo}

O DNA de camundongos da geração F0 foi submetido ao qPCR para avaliar o número de cópias do KLC2 humano no genoma dos camundongos (Figura 11). Dos sete camundongos positivos para o transgênico $K L C 2$, duas linhagens tiveram baixo número de cópias do transgene 
e esses animais foram sacrificados (a linhagem F4193 apresentou de uma a duas cópias e a linhagem B4676 apenas uma cópia do transgene). As cinco linhagens F0 restantes (F4190, B4648, B4652, B4657 e B4680), sendo todas formadas por indivíduos machos, apresentaram entre seis a 20 cópias do $K L C 2$ humano em seu genoma.

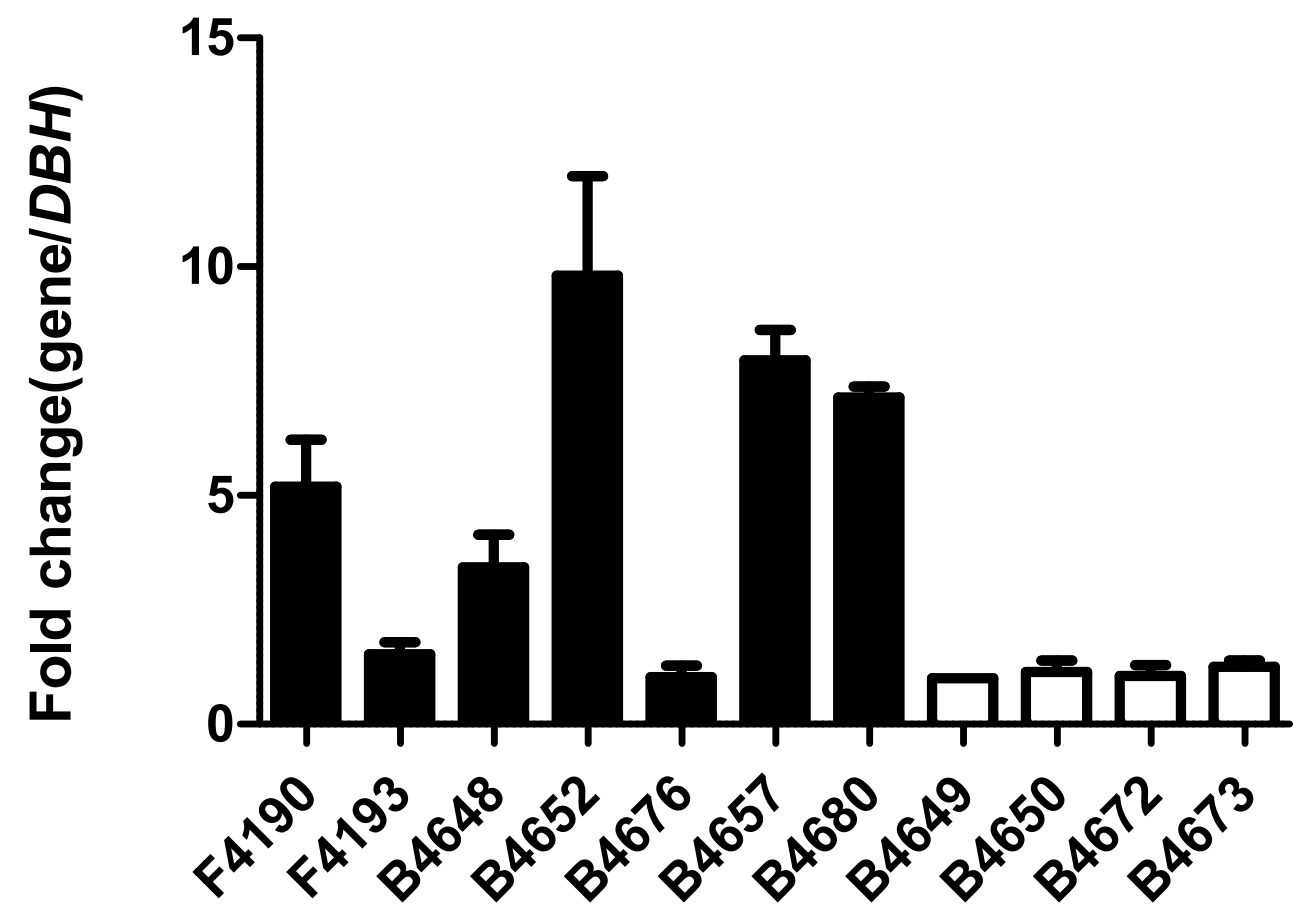

Figura 11. qPCR mostrando o número de cópias do $K L C 2$ humano inseridos no genoma de camundongos da linhagem F0. Os camundongos positivos para o transgene $K L C 2$ estão representados por colunas pretas e os camundongos wild-type para o transgene estão representados por colunas brancas, pareados por ninhada. A linhagem B4649 é wild-type para o transgene e foi usada como calibrador. Cada experimento foi realizado em triplicata e cada amostra de DNA foi replicada duas vezes. As analises da variação do número de cópias foi realizada usando o método $2^{-\Delta \Delta C T}$.

Os cinco camundongos da geração F0 foram avaliados clinicamente durante sete semanas em busca de fenótipos grosseiros associados à neurodegeneração. A principal avaliação foi a perda de peso, o que após 16 semanas de vida não foi detectada nos transgênicos quando 
comparados com controles pareados por sexo e ninhada (Figura 12). Além disso, após a $16^{\mathrm{a}}$ semana os camundongos não apresentaram fenótipo que pudesse ser associado à neurodegeneração, tal qual tremores nas patas e deformidade esquelética.

A

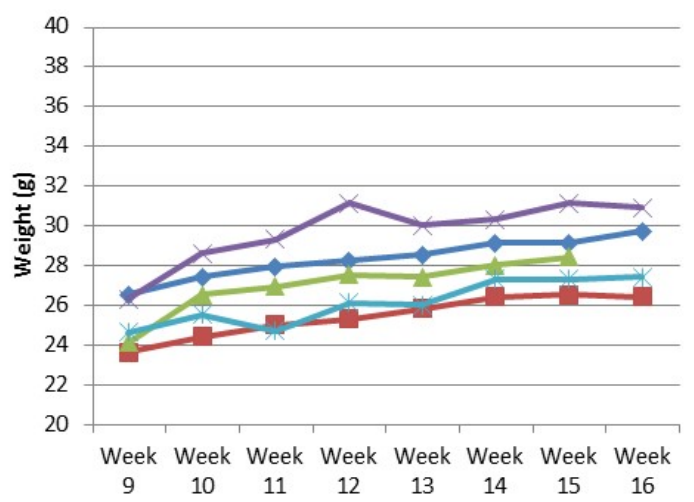

C

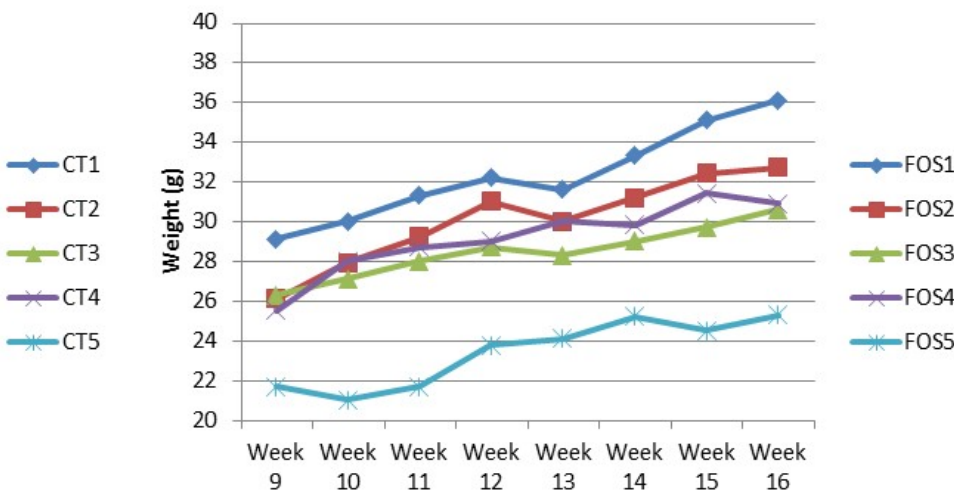

B

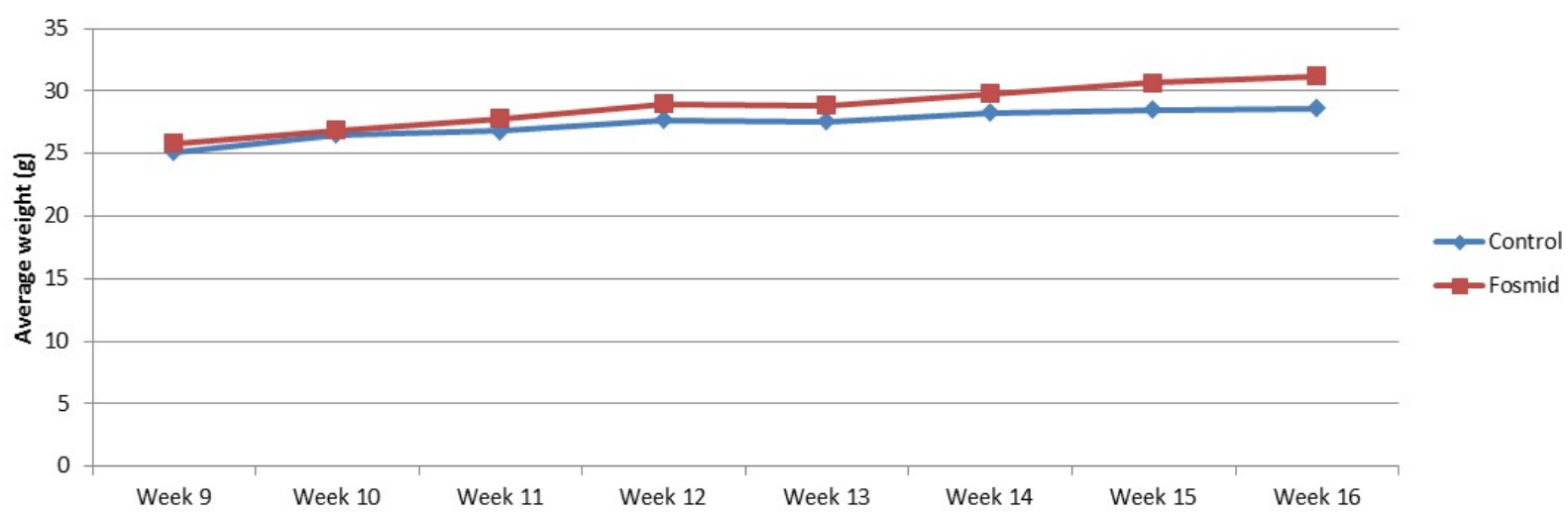

Figura 12. Gráficos mostrando a avaliação do peso dos camundongos transgênicos e controles durante sete semanas. (A) Cinco controles machos wild-type. (C) Cinco transgênicos machos. (B) Média de peso dos camundongos transgênicos e wild-type.

Nós cruzamos as cinco linhagens de camundongos F0 com fêmeas wild-type FVB/N para gerar duas proles de camundongos F1: a primeira ninhada (first breed) foi gerada para coletar RNA de tecido cerebral a fim de confirmar a superexpressão do transgene; e a segunda ninhada (second breed) para gerar linhagens estáveis para estudos posteriores. 


\subsubsection{Camundongos da geração F1}

Os camundongos da geração F1 da primeira ninhada (first breed) foram sacrificados 10 dias após o nascimento (P10) e tiveram seus cérebros dissecados para extração de RNA. qRTPCR usando o cDNA de tecido cerebral mostrou superexpressão do $K L C 2$ em quatro das cinco linhagens testadas (Figura 13). A linhagem B4652 foi considerada mosaico pois não transmitiu o Fosmídeo do KLC2 para sua descendência (nenhum dos 38 filhotes dessa linhagem foram positivos para o transgene), sendo sacrificada em seguida. Os camundongos F1 da linhagem B4648 mostraram uma relativa baixa expressão do transgene (quatro a seis vezes em comparação com controles) e essa linhagem também foi sacrificada e não incluída em estudos posteriores (Figura 13B). Embora os camundongos $F 1$ da linhagem $F 4190$ apresentaram alta expressão do KLC2 humano (média de 20 vezes), os camundongos da geração F0 dessa linhagem apresentou baixo número de cópias no experimento de qPCR (Figura 11), e por isso não demos continuidade a essa linhagem para demais estudos. No final, selecionamos duas linhagens que apresentaram alto número de cópias do transgene detectado no experimento de qPCR da geração F0 combinado com alta expressão do KLC2 em camundongos da geração F1 (B4657 e B4680). Essas duas linhagens foram cruzadas com fêmeas wild-type para gerar linhagens estáveis da second breed. 
A

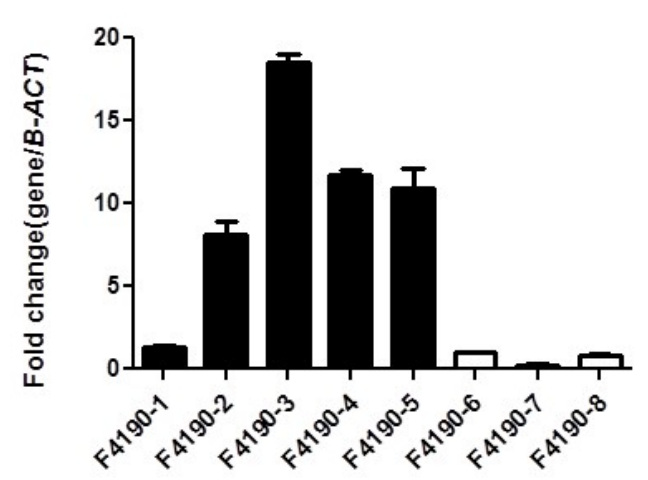

B

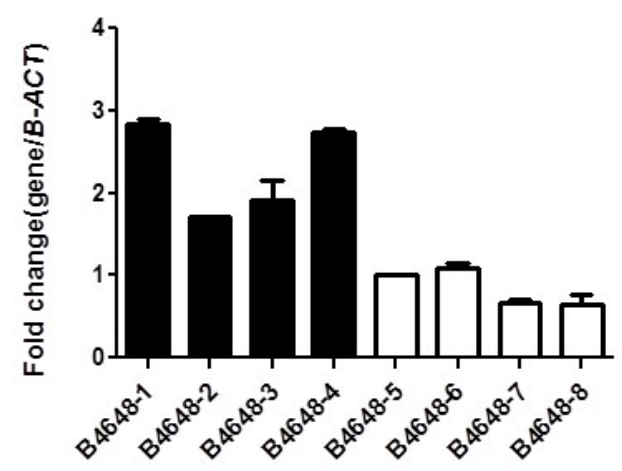

C



D

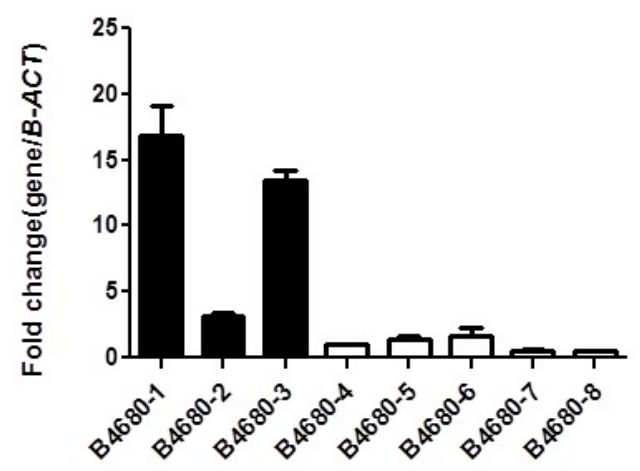

Figura 13. qRT-PCR usando cDNA de cérebro de camundongos transgênicos coletados no estágio de P10 comparados com o mesmo tecido de camundongos wild-type, pareados para a mesma ninhada. Os camundongos positivos para o transgene $K L C 2$ estão representados por colunas pretas e os camundongos wild-type para o transgene estão representados por colunas brancas. (A) Os camundongos F1 da linhagem F4190 apresentaram superexpressão do $K L C 2$, sendo o gene humano superexpresso em média 20 vezes em comparação com controles. (B) A ninhada F1 da linhagem B4648 apresentou superexpressão do $K L C 2$ entre quatro a seis vezes quando comparados com controles. (C) Apenas um camundongo F1 do B4657 foi positivo para o transgene e o gene humano apresentou-se $\sim 20$ vezes mais expresso em comparação com controles. (D) Camundongos F1 do B4680 apresentaram superexpressão do transgene variando de oito a $\sim 30$ vezes em relação aos controles.

As duas linhagens estáveis de camundongos da geração F1 (second breed) tiveram suas amostras de DNA submetidas a analise do número de cópias do transgene por meio de qPCR. Da linhagem B4657, nós obtivemos quatro filhotes (C0682, C0683, C0685 e C0684) que 
apresentaram aproximadamente 14 cópias do $K L C 2$ humano em seu genoma (Figura 14A). A linhagem B4680 gerou seis filhotes (C0697, C0698, C0699, C0696, B4748 e B4749) apresentando em média 30 a 40 cópias do Fosmídeo (Figura 14B). As duas linhagens F1 foram acompanhadas por oito semanas em busca de fenótipos grosseiros relacionados a doenças neurodegenerativas, porém, até a última semana, os camundongos transgênicos não apresentaram nenhuma característica clínica sugestiva de neurodegeneração.

A

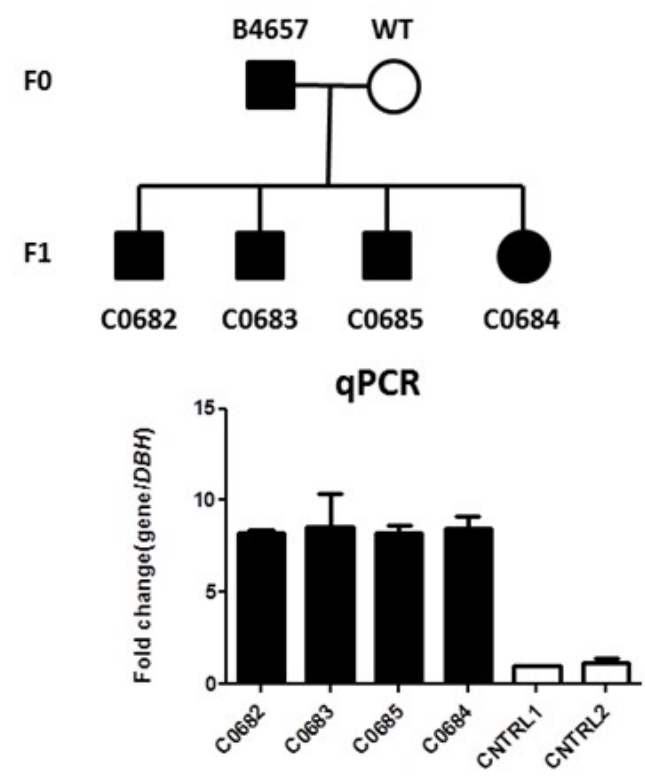

B
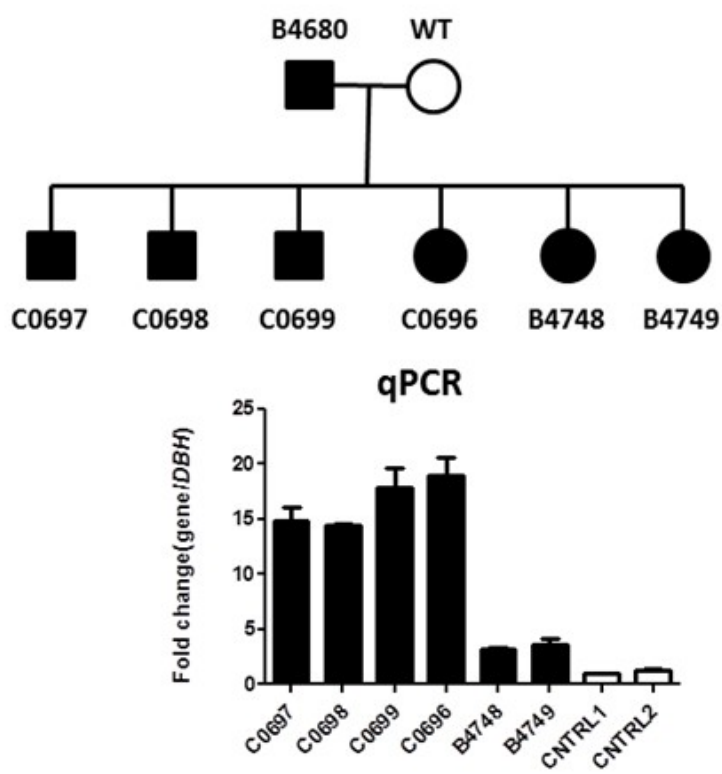

Figura 14. Genealogia dos camundongos e resultado do qPCR mostrando o número de cópias do KLC2 humano nos camundongos transgênicos da geração F1. Os camundongos positivos para o transgene $K L C 2$ estão representados por colunas pretas e os camundongos wild-type para o transgene estão representados por colunas brancas, pareados por ninhada. (A) Os camundongos F1 da linhagem B4657 apresentaram aproximadamente 14 cópias do transgene cada. (B) Os camundongos F1 da linhagem B4680 apresentaram em média 30 a $\sim 40$ cópias do Fosmídeo.

Após não detectarmos nenhuma característica sugestiva de neurodegeneração noss camundongos $\mathrm{F} 1$, decidimos então gerar camundongos da geração F2 intercruzando os da F1, a 
fim de aumentarmos o número de cópias do transgene e consequentemente aumentar a superexpressão do $K L C 2$ humano. Dessa forma, poderíamos observar um fenótipo associado à neurodegeneração em um espaço menor de tempo. Para isso, intercruzamos a fêmea C0684 (da linhagem B4657) com o macho C0697 (da linhagem B4680). Além disso, intercruzamos os irmãos F1 da linhagem B4680 que apresentaram o maior número de cópias transgênicas (macho C0699 com fêmea C0696). Três camundongos da geração F2 apresentaram aproximadamente 80 cópias do transgene em seu genoma (C1851, C1853 e C1857; Figura 15). Esses camundongos foram acompanhados por oito semanas para avaliação de fenótipo grosseiro associado à neurodegeneração, porém, até a última semana de vida eles não apresentaram fenótipo sugestivo e os camundongos foram sacrificados. 

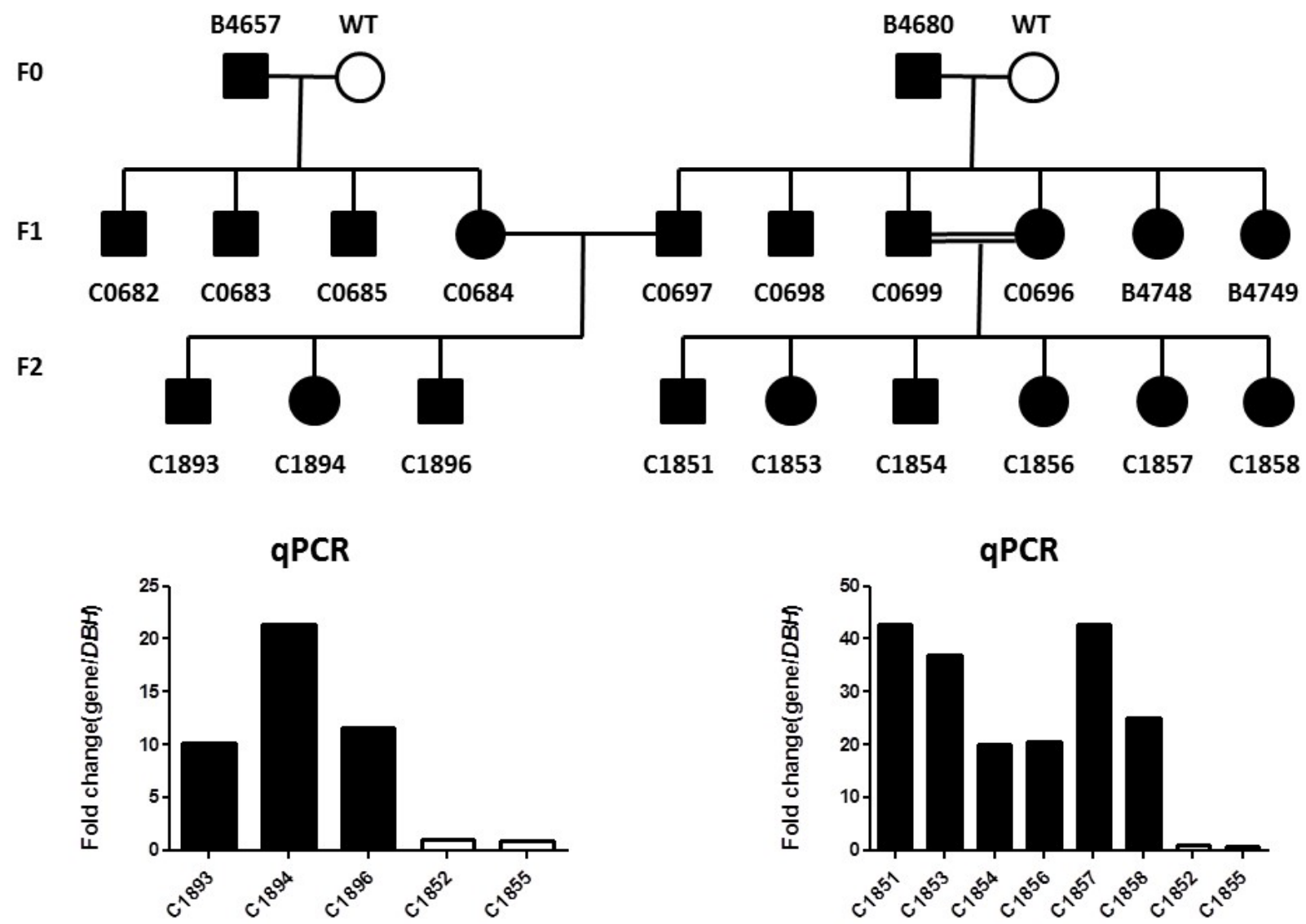

Figura 15. Genealogia simples e qPCR mostrando o número de cópias do $K L C 2$ humano nos camundongos transgênicos da geração F2. Os camundongos positivos para o transgene $K L C 2$ estão representados por colunas pretas e os camundongos wild-type para o transgene estão representados por colunas brancas, pareados por ninhada. Os camundongos F2 resultantes do cruzamento de duas linhagens diferentes (C0684 com C0697) apresentaram entre 20 a 40 cópias do KLC2 humano. O intercruzamento da linhagem B4680 (C0699 com C0696) resultou em camundongos com 80 cópias do Fosmídeo.

Camundongos transgênicos vêm sido utilizados desde a década de 80 como modelo de doenças neuromusculares e neurodegenerativas (Bulfield et al., 1984). Dentre os principais achados clínicos nos camundongos modelos para as doenças neurodegenerativas estão a diminuição da longevidade, fraqueza muscular, tremores nas patas e deformidade e distrofia esquelética. Esses camundongos apresentam uma grande variação em relação ao início do 
surgimento das características sugestivas de neurodegeneração, em alguns casos o aparecimento da condição surge em quatro semanas e em outros em até 20 semanas de vida, como por exemplo em casos mais graves como a perda de função de dois genes simultaneamente (Durbeej \& Campbell, 2002). Em alguns outros modelos, o fenótipo de neurodegeneração é observado apenas após de 12 meses de vida do animal (Vainzof et al., 2008). No caso das diferentes linhagens dos nossos camundongos transgênicos, não observamos nenhum fenótipo sugestivo de neurodegeneração nesses animais. O fato de não termos encontrado nenhum fenótipo sugestivo da síndrome SPOAN nesses camundongos pode ser devido ao curto tempo de observação desses animais, visto que foram sacrificados pouco tempo após a maturação sexual (oito semanas). Além disso, ensaios físicos e comportamentais não foram realizados para verificar diferenças sutís nos camundongos trangênicos em relação aos controles normais.

\section{Considerações finais e perspectivas futuras}

Nesta tese de doutorado foram realizados estudos moleculares da síndrome SPOAN que permitiram identificar o gene e a variante patogênica associada ao fenótipo. Após a descrição da doença em 2005, foram necessários praticamente dez anos para que esta variante patogênica fosse identificada com auxílio de sequenciamento de nova geração. Inicialmente, foi realizado o sequenciamento do exoma e não foi detectada a variante patogênica causadora da síndrome SPOAN, mesmo com o mapeamento da região de ligação associada à síndrome. De fato, a variante patogênica foi encontrada em uma região regulatória do KCL2 e esta descoberta foi possível apenas com uso do sequenciamento completo do genoma. Esta abordagem ainda é muito pouco utilizada para detecção de variantes patogênicas associadas a doenças genéticas raras, visto que o custo financeiro de execução desse sequenciamento, bem como a dificuldade 
para analisar o resultado oriundo desse experimento, ainda não são condições a serem executadas em rotina nos laboratórios brasileiros. Essa metodologia nos permitiu identificar a deleção de 216-pb em homozigose na região regulatória do $K L C 2$, deleção essa que segregou em homozigose nos 75 pacientes com a síndrome SPOAN e não foi detectada em duas cópias em controles normais e familiares.

Surpreendentemente, essa deleção que se localiza em região promotora ao invés de causar perda de função do $K L C 2$ diminuindo sua expressão, causa superexpressão desse gene. Ensaios de qRT-PCR em amostras de fibroblastos e NM, de pacientes em comparação com controles, confirmou essa superexpressão. O mesmo padrão de superexpressão não foi observado usando qRT-PCR em um número maior de amostras de sangue de pacientes, de heterozigotos e de controles familiares, indicando que essa deleção teria apenas função em determinados tipos celulares. Após a validação da superexpressão usando o modelo in vitro, decidimos realizar estudos de knockdown e de superexpressão do klc2 em modelo in vivo usando o Danio rerio (zebrafish). Ambos os ensaios revelaram que a desregulação da expressão do klc2 acarreta em fenótipo sugestivo de neurodegeneração nesse modelo animal. Aqui demonstramos pela primeira vez uma doença de herança autossômica recessiva causada por ganho de função, ou seja, uma deleção em região reguladora do $K L C 2$ causando a superexpressão desse gene.

Por fim, na tentativa de modelar essa síndrome em modelo murino, geramos linhagens transgênicas com o KLC2 humano inserido no genoma dos camundongos em diversas cópias. Estudos de qRT-PCR em tecido cerebral de camundongos transgênicos confirmaram a superexpressão do KLC2. Infelizmente, não houve tempo hábil para realizar ensaios físicos e comportamentais em camundongos com alta expressão do KLC2 humano para verificar 
características sugestivas de neurodegeneração e validar esse transgênico como modelo para essa doença.

Algumas questões continuam em aberto em relação ao mecanismo molecular de atuação da deleção de 216-pb em homozigose como causadora da síndrome SPOAN: Qual o mecanismo molecular é afetado pela deleção na região regulatória do KLC2? Perda de ligação de determinados fatores de transcrição? Ganho de ligação de outros fatores de transcrição na região? Mudança na regulação da cromatina nessa região por meio da mudança molecular das caudas das histonas? Perda de algum repressor que se liga a essa região wild-type? Perda ou alteração do padrão de metilação dessa região? Além dessas questões moleculares, porque os heterozigotos não apresentam nenhum fenótipo relacionado a essa síndrome, mesmo os indivíduos mais velhos? Estudos futuros realizando experimentos específicos para responder cada uma dessas questões podem vir a revelar o mecanismo molecular causador da fisiopatologia de neurodegeneração dos neurônios motores da síndrome SPOAN. 


\section{Referências}

Akhmanova A \& Hammer J. (2010). Linking molecular motors to membrane cargo. Curr Opin Cell Biol 22:479-489.

Altschul S, Madden T, Schaffer A, Zhang J, Zhang Z, Miller W, Lipman D. (1997). Gapped BLAST and PSI-BLAST: a new generation of protein database search programs. Nucleic Acids Res 25(17):3389-3402.

Amorim S, Heise C, Santos S, Macedo-Souza L, Zatz M, Kok F. (2014). Nerve conduction studies in spastic paraplegia, optic atrophy, and neuropathy (SPOAN) syndrome. Muscle Nerve. 49(1):131-3.

Araki Y, Kawano T, Taru H, Saito Y, Wada S, et al. (2007) The novel cargo Alcadein induces vesicle association of kinesin-1 motor components and activates axonal transport. Embo $\mathrm{J}$ $26: 1475-1486$.

Audhya A, Desai A, Oegema K. (2007). A role for Rab5 in structuring the endoplasmic reticulum. J Cell Biol 178(1):43-56.

Baird F \& Bennett C. (2013). Microtubule defects \& Neurodegeneration. J Genet Syndr Gene Ther. 6;4:203.

Bayrakli F, Poyrazoglu H, Yuksel S, Yakicier C, Erguner B, Sagiroglu MS, Yuceturk B, Ozer B, Doganay S, et al. (2015). Hereditary spastic paraplegia with recessive trait caused by mutation in KLC4 gene. J Hum Genet. 60(12):763-8.

Bian X, Iemm R, Liu T, Zhang M, Sun S, Sui X, Liu X, Rapoport T, Hu J. (2011). Structures of the atlastin GTPase provide insight into homotypic fusion of endoplasmic reticulum membranes. Proc Natl Acad Sci USA 108(10):3976-3981.

Blackstone C, O’Kane C, Reid E. (2011). Hereditary Spastic Paraplegia: Membrane traffic and the motor pathway. Nat Rev Neurosci 12(1):31-42.

Bloom G, Wagner M, Pfister K, Brady S. (1988). Native structure and physical properties of bovine brain kinesin and identification of the ATP-binding subunit polypeptide. Biochemistry 27:3409-3416.

Bracale A, Cesca F, Neubrand V, Newsome T, Way M, et al. (2007). Kidins220/ARMS is transported by a kinesin-1-based mechanism likely to be involved in neuronal differentiation. Mol Biol Cell 18: 142-152. 
Brickley K \& Stephenson F. (2011). Trafficking kinesin protein (TRAK) mediated transport of mitochondria in axons of hippocampal neurons. J.Biol.Chem. 286, 18079-18092.

Birsa N, Norkett R, Higgs N, Lopez-Domenech G, Kittler J. (2013). Mitochondrial trafficking in neurons and the role of the Miro family of GTPase proteins. Biochem Soc Trans 41:15251531.

Bulfield G, Siller W, Wight P, Moore K. (1984). X Chromosome-linked muscular dystrophy $(\mathrm{mdx})$ in the mouse. Proceedings of the National Academy of Sciences of the United States of America, 81, 1189-1192.

Butler R, Wood J, Landers J, Cunliffe V. (2010). Genetic and chemical modulation of spasticdependent axon outgrowth in zebrafish embryos indicates a role for impaired microtubule dynamics in hereditary spastic paraplegia. Dis Model Mech 3(11-12):743-751.

Caballero Oteyza A, et al. (2014). Motor protein mutations cause a new form of hereditary spastic paraplegia. Neurology 3, 2007-2016.

Cabeza-Arvelaiz Y, Shih L, Hardman N, Asselbergs F, Bilbe G, Schmitz A, White B, Siciliano M, Lachman L. (1993). Cloning and genetic characterization of the human kinesin lightchain (KLC) gene. DNA Cell Biol 12(10):881-892.

Carter A. (2013). Crystal clear insights into how the dynein motor moves. J Cell Sci. $1 ; 126(3): 705-13$.

Casari G, et al. (1998). Spastic paraplegia and OXPHOS impairment caused by mutations in paraplegin, a nuclear-encoded mitochondrial metalloprotease. Cell 93, 973-983.

Cho K, Cai Y, Yi H, Yeh A, Aslanukov A, Ferreira P. (2007). Association of the kinesin-binding domain of RanBP2 to KIF5B and KIF5C determines mitochondria localization and function. Traffic 8.

Cingolani P, Platts A, Wang le L, Coon M, Nguyen T, Wang L, Land SJ, Lu X, Ruden DM. (2012). A program for annotating and predicting the effects of single nucleotide polymorphisms, SnpEff: SNPs in the genome of Drosophila melanogaster strain w1118; iso2; iso-3. Fly (Austin) 6(2):80-92.

Clemen C, Tangavelou K, Strucksberg K, Just S, Gartner L, Regus-Leidig H, Stumpf M, Reimann J, Coras R, et al. (2010). Strumpellin is a novel valosin-containing protein binding partner linking hereditary spastic paraplegia to protein aggregation diseases. Brain 133(10):2920-2941. 
Collard J, Côté F, Julien J. (1995). Defective axonal transport in a transgenic mouse model of amyotrophic lateral sclerosis. Nature 4;375(6526):61-4.

Connell J, Lindon C, Luzio J, Reid E. (2009). Spastin couples microtubule severing to membrane traffic in completion of cytokinesis and secretion. Traffic 10(1):42-56.

D’Andrea L \& Regan L. (2003). TPR proteins: the versatile helix. Trends Biochem Sci 28: 655662.

Debray F, Stümpfig C, Vanlander A, Dideberg V, Josse C, Caberg J, Boemer F, Bours V, et al. (2015). Mutation of the iron-sulfur cluster assembly gene IBA57 causes fatal infantile leukodystrophy. J Inherit Metab Dis.38(6):1147-53.

Diefenbach R, Mackay J, Armati P, Cunningham A. (1998). The C-terminal region of the stalk domain of ubiquitous human kinesin heavy chain contains the binding site for kinesin light chain. Biochemistry 37(47):16663-16670.

Dion P, Daoud H, Rouleau G. (2009). Genetics of motor neuron disorders: new insights into pathogenic mechanisms. Nature Rev Genet 10:769-782.

Durbeej M \& Campbell K. (2002). Muscular dystrophies involving the dystrophin-glycoprotein complex: an overview of current mouse models. Current Opinion in Genetics \& Development 12, 349-361.

Dykstra K, Pokusa J, Suhan J, Lee T. (2010). Yip1A structures the mammalian endoplasmic reticulum. Mol Biol Cell 21(9):1556-1568.

Ebbing B, et al. (2008). Effect of spastic paraplegia mutations in KIF5A kinesin on transport activity. Hum Mol Genet 17:1245-1252.

Eppig J, Blake J, Bult C, Kadin J, Richardson J, The Mouse Genome Database Group. (2015). The Mouse Genome Database (MGD): facilitating mouse as a model for human biology and disease. Nucleic Acids Res. 28;43:D726-36.

Ernst J, et al. (2011). Mapping and analysis of chromatin state dynamics in nine human cell types. Nature 5, 43-49.

Falzone T, et al. (2009). Axonal Stress Kinase Activation and Tau Misbehavior Induced by Kinesin-1 Transport Defects. J. Neurosci. 29, 5758.

Fassier C, Hutt J, Scholpp S, Lumsden A, Giros B, Nothias F, Schneider-Maunoury S, Houart C, Hazan J. (2010). Zebrafish atlastin controls motility and spinal motor axon architecture via inhibition of the BMP pathway. Nat Neurosci 13(11):1380-1387. 
Fink J. (2006). Hereditary Spastic Paraplegia. Curr Neurol Neurosci Rep 6(1):65-76.

Finsterer J, Loscher W, Quasthoff S, Wanschitz J, Auer-Grumbach M, Stevanin G. (2012). Hereditary spastic paraplegias with autosomal dominant, recessive, X-linked, or maternal trait of inheritance. J Neurol Sci 318(1-2):1-18.

Friedman J \& Voeltz G. (2011). The ER in 3D: A multifunctional dynamic membrane network. Trends Cell Biol 21(12):709-717.

Fujita T, Maturana A, Ikuta J, Hamada J, Walchli S, Suzuki T, Sawa H, et al. (2007). Axonal guidance protein FEZ1 associates with tubulin and kinesin motor protein to transport mitochondria in neurites of NGF stimulated PC12 cells. Biochem. Biophys. Res. Commun. 361(2007)605-610.

Gan-Or Z, Bouslam N, Birouk N, Lissouba A, Chambers D, Vérièpe J, Androschuk A, Laurent $\mathrm{S}$, et al. (2016). Mutations in CAPN1 Cause Autosomal-Recessive Hereditary Spastic Paraplegia. Am J Hum Genet. 2;98(6):1271.

Gindhart J, Desai C, Beushausen S, Zinn K, Goldstein L. (1998). Kinesin light chains are essential for axonal transport in Drosophila. J Cell Biol 141: 443-454.

Glater E, Megeath L, Stowers R, Schwarz T. (2006). Axonal transport of mitochondria requires Milton to recruit kinesin heavy chain and is light chain independent. J.CellBiol. 173, 545557.

Hackney D. (2007). Jump-starting kinesin. J Cell Biol 176(1):7-9.

Halevy A, Lerer I, Cohen R, Kornreich L, Shuper A, Gamliel M, Zimerman B, Korabi I, Meiner V, Straussberg R, Lossos A. (2014). Novel EXOSC3 mutation causes complicated hereditary spastic paraplegia. J Neurol. 261 (11):2165-9.

Hansen J, et al. (2002). Hereditary spastic paraplegia SPG13 is associated with a mutation in the gene encoding the mitochondrial chaperonin Hsp60. Am. J. Hum. Genet. 70, 1328-1332.

Hazan J, Fonknecheten N, Mavel D, Paternotte C, Samson D, Artiguenave F, Davoine Cm Cruaud C, et al. (1999). Spastin, a new AAA protein, is altered in the most frequent form of autosomal dominant spastic paraplegia. Nat Genet 23(3):296-303.

Hirokawa N, Noda Y, Tanaka Y, Niwa S. (2009). Kinesin superfamily motor proteins and intracellular transport. Nat Rev Mol Cell Biol 10:682-696.

Hirokawa N, Niwa S, Tanaka Y. (2010). Molecular motors in neurons: transport mechanisms and roles in brain function, development, and disease. Neuron 68, 610-638. 
Hurd D \& Saxton W. (1996). Kinesin mutations cause motor neuron disease phenotypes by disrupting fast axonal transport in Drosophila. Genetics 144, 1075-1085.

Ikenaka K, Katsuno M, Kawai K, Ishiasku S, Tanaka F, Sobue G. (2012). Disruption of axonal transport in motor neuron diseases. Int J Mol Sci 13(1):1225-1238.

Kamal A \& Goldstein L. (2002). Principles of cargo attachment to cytoplasmic motor proteins. Curr Opin Cell Biol 14: 63-68.

Kamm C, Boston H, Hewett J, Wilbur J, Corey D, et al. (2004) The early onset dystonia protein torsinA interacts with kinesin light chain 1. J Biol Chem 279:19882-19892.

Kimura T, Watanabe H, Iwamatsu A, Kaibuchi K. (2005). Tubulin and CRMP-2 complex is transported via Kinesin-1. J Neurochem 93: 1371-1382.

Konecna A, Frischknecht R, Kinter J, Ludwig A, Steuble M, et al. (2006) Calsyntenin-1 docks vesicular cargo to kinesin-1. Mol Biol Cell 17: 3651-3663.

Koutsopoulos O, Laine D, Osellame L, Chudakov D, Parton R, Frazier E, Ryan M. (2010). Human Miltons associate with mitochondria and induce microtubule-dependent remodeling of mitochondrial networks. Biochim.Biophys.Acta 1803, 564-574.

Lalioti V, Vergarajauregui S, Tsuchiya Y, Hernandez-Tiedra S, Sandoval I. (2009). Daxx functions as a scaffold of a protein assembly constituted by GLUT4, JNK1 and KIF5B. J Cell Physiol 218: 416-426.

Li H \& Durbin R. (2010). Fast and accurate long-read alignment with Burrows-Wheeler transform. Bioinformatics, 26,589-595.

Lipka J, Kuijpers M, Jaworski J, Hoogenraad C. (2013). Mutations in cytoplasmic dynein and its regulators cause malformations of cortical development and neurodegenerative diseases. Biochem Soc Trans. 41(6):1605-12.

Lin P, Li J, Liu Q, Mao F, Li J, Qiu R, Hu H, Song Y, Yang Y, Gao G, Yan C, Yang W, Shao C, Gong Y. (2008). A missense mutation in SLC33A1, which encodes the actyl-CoA transporter, causes autosomal-dominant spastic paraplegia (SPG42). Am J Hum Genet 83(6):752-759.

Lin M \& Sheng Z. (2015). Regulation of mitochondrial transport in neurons. Exp Cell Res. 2015 $15 ; 334(1): 35-44$. 
Lo Giudice T, Lombardi F, Santorelli FM, Kawarai T, Orlacchio A. (2014). Hereditary spastic paraplegia: clinical-genetic characteristics and evolving molecular mechanisms. Exp Neurol. 261:518-39.

Lossos A, Stümpfig C, Stevanin G, Gaussen M, Zimmerman B, Mundwiller E, Asulin M, et al. (2015). Fe/S protein assembly gene IBA57 mutation causes hereditary spastic paraplegia. Neurology. 17;84(7):659-67.

Macaskill A, Brickley K, Stephenson F, Kittler J. (2009). GTPase dependent recruitment of Grif1 by Miro1 regulates mitochondrial trafficking in hippocampal neurons. Mol.Cell.Neurosci. 40, 301-312.

Macedo-Souza L, Kok F, Santos S, Amorim S, Starling A, Nishimura A, Lezirovitz K, Lino A, Zatz M. (2005). Spastic paraplegia, Optic Atrophy and Neuropathy (SPOAN Syndrome) is linked to chromosome 11q13. Annals of Neurology 57(5):730-737.

Macedo-Souza L, Kok F, Santos S, Licinio L, Lezirovitz K, Nascimento R., Bueno C, Martyn M, Ekea L, Zatz M. (2009). Spastic paraplegia, optic atrophy and neuropathy: new observations, locus refinement, and exclusion of candidate genes. Ann Hum Genet 73(3): 382-387.

Maeder C, Shen K, Hoogenraad C. (2014). Axon and dendritic trafficking. Curr Opin Neurobiol. 27:165-70.

Mandelkow E \& Mandelkow E. (2002) Kinesin motors and disease. Trends Cell Biol 12: 585591.

Mannan A, Boehm J, Sauter S, Rauber A, Byrne P, Neesen J, Engel W. (2006). Spastin, the most commonly mutated protein in hereditary spastic paraplegia interacts with Reticulon 1 an endoplasmic reticulum protein. Neurogenetics 7(2):93-103.

Martin E, Yanicostas C, Rastetter A, Naini S, Maoudj A, Kabashi E, Rivaud-Péchoux S, Brice A, Stevanin G, Soussi-Yanicostas N. (2012). Spatacsin and spastizin act in the same pathway required for proper spinal motor neuro axon out growth in zebrafish. Neurobiol Dis 48(3):299-308.

Martin E, Schule R, Smets K, Rastetter A, Boukhris A, Loureiro J, Gonzalez M, Mundwiller E, Deconinck T, Wessner M, Jornea L, et al. (2013). Loss of funciont of glucocerebrosidase GBA2 is responsible for motor neuron defects in hereditary spastic paraplegia. Am J Hum Genet 92(2):238-244. 
McGuire J, Rong J, Li S, Li X. (2006). Interaction of Huntingtin-associated protein-1 with kinesin light chain: implications in intracellular trafficking in neurons. J Biol Chem 281: $3552-3559$.

McKenna A, Hanna M, Banks E, Sivachenko A, Cibulskis K, Kernytsky A, Garimella K, Altshuler D, Gabriel S, Daly M, et al. (2010). The Genome Analysis Toolkit: a MapReduce framework for analyzing next-generation DNA sequencing data. Genome Res., 20, $1297-$ 1303.

Melo U, Macedo-Souza L, Figueiredo T, Muotri A, Gleeson J, Coux G, Armas P, Calcaterra N, et al. (2015). Overexpression of KLC2 due to a homozygous deletion in the non-coding region causes SPOAN syndrome. Hum Mol Genet. 2015 15;24(24):6877-85.

Millecamps S \& Julien J. (2013). Axonal transport deficits and neurodegenerative diseases. Nat Rev Neurosci 14(3):161-176.

Montenegro G, Rebelo A, Connell J, Allison R, Babalini C, D’Aloia M, Montieri P, Schule R, Ishjura $\mathrm{H}$ et al. (2012). Mutations in the ER-shaping protein reticulon 2 cause the axondegenerative disorder hereditary spastic paraplegia type 12. J Clin Invest 122(2):538-544.

Morihara T, Hayashi N, Yokokoji M, Akatsu H, Silverman MA, Kimura N, Sato M, Saito Y, Suzuki T, Yanagida K et al. (2014). Transcriptome analysis of distinct mouse strains reveals kinesin light chain-1 splicing as an amyloid- $\beta$ accumulation modifier. Proc Natl Acad Sci U S A. 18;111(7):2638-43.

Munch C, et al. (2005). Heterozygous R1101K mutation of the DCTN1 gene in a family with ALS and FTD. Ann. Neurol. 58, 777.

Nobrega M, Ovcharenko I, Afzal V, Rubin E. (2003). Scanning human gene deserts for longrange enhancers. Science 302, 413.

Novarino G, et al. (2014). Exome sequencing links corticospinal motor neuron disease to common neurodegenerative disorders. Science 31, 506-511.

OMIM. (2016). Online Mendelian Inheritance in Man. World Wide Web URL: http://www.omim.org Acesso em Junho de 2016.

Park S \& Blackstone C. (2010). Further assembly required: Construction and dynamics of the endoplasmic reticulum network. EMBO Rep 11(7):515-521. 
Park SH, Zhu PP, Parker RL, Blackstone C. (2010). Hereditary spastic paraplegia proteins REEP1, spastin, and atlastin-1 coordinate microtubule interactions with the tubular ER network. J Clin Invest 120(4):1097-1110.

Pernigo S, Lamprecht A, Steiner R, Doodding M. (2013). Structural basis for kinesin-1: cargo recognition. Science 340:356-359.

Philips T \& Rothstein J. (2015). Rodent Models of Amyotrophic Lateral Sclerosis. Curr Protoc Pharmacol. 1;69:5.67.1-5.67.21.

Pilling A, Horiuchi D, Lively C, Saxton W. (2006). Kinesin-1 and Dynein are the primary motors for fast transport of mitochondria in Drosophila motor axons. Mol.Biol.Cell 17, 2057-2068.

Plagnol V, Curtis J, Epstein M, Mok K, Stebbings E, Grigoriadou S, Wood N, Hambleton S, Burns S, Thrasher A, et al. (2012). A robust model for read count data in exome sequencing experiments and implications for copy number variant calling. Bioinformatics, 28, 27472754.

Rahman A, Friedman D, Goldstein L. (1998). Two kinesin light chain genes in mice. Identification and characterization of the encoded proteins. J Biol Chem 273(25):1539515403.

Rahman A, Kamal A, Roberts E, Goldstein L. (1999). Defective kinesin heavy chain behavior in mouse kinesin light chain mutants. J Cell Biol 146:1277-1288.

Reid E, et al. (2002). A kinesin heavy chain (KIF5A) mutation in hereditary spastic paraplegia (SPG10). Am. J. Hum. Genet. 71, 1189-1194.

Renvoise B \& Blackstone C. (2010). Emerging themes of ER organization in the development and maintenance of axons. Curr Opin Neurobiol 20(5):531-537.

Salinas S, Proukakis C, Crosby A, Warner T. (2008). Hereditary Spastic Paraplegia: clinical features and pathogenetic mechanisms. Lancet Neurol 7(12):1127-1138.

Santos S, Kok F, Weller M, Paiva F, Otto P. (2010). Inbreeding levels in Northeastern Brazil: strategies for the prospection of new genetic disorders. Genetics and Molecular Biology $33: 1-2$

Schmittgen T \& Livak K. (2008). Analyzing real-time PCR data by the comparative C(T) method. Nat. Protoc., 3, 1101-1108. 
Schule R \& Schols L. (2011). Genetics of hereditary spastic paraplegia. Semin Neurol 31(5):484-493.

Sheng Z \& Cai Q. (2012). Mitochondrial transport in neurons: impact on synaptic homeostasis and neurodegeneration. Nat.Rev. Neurosci.13, 77-93.

Soderblom C \& Blackstone C. (2006). Traffic accidents: Molecular genetic insights into the pathogenesis of the hereditary spastic paraplegia. Pharmacol Ther 109(1-2):42-56.

Song Y, Wang M, Mao F, Shao M, Zhao B, Song Z, Shao C, Gong Y. (2013). Knockdown of Pnpla6 protein results in motor neuron defects in zebrafish. DIs Model Mech 6(2):404-413.

Southgate L, Dafou D, Hoyle J, Li N, Kinning E, Critchley P, Nemeth A, Talbot K, et al. (2010). Novel SPG11 mutations in Asian kindreds and disruption of spatacsin function in the zebrafish. Neurogenetics 11(4):379-389.

van Spronsen M, Mikhaylova M, Lipka J, Schlager M, van den Heuvel D, et al. (2013). TRAK/Milton motor-adaptor proteins steer mitochondrial trafficking to axons and dendrites. Neuron77 (2013), 485-502.

Stevanin G, Ruberg M, Brice A. (2008). Recent advances in the genetics of spastic paraplegias. Curr Neurol Neurosci Rep 8:198-210.

Stokin G, Lillo C, Falzone T, Brusch R, Rockenstein E, et al. (2005) Axonopathy and transport deficits early in the pathogenesis of Alzheimer's disease. Science 307: 1282-1288.

Stowers R, Megeath L, Górska-Andrzejak J, Meinertzhagen I, Schwarz T. (2002). Axonal transport of mitochondria to synapses depends on milton, a novel Drosophila protein. Neuron 36, 1063-1077.

Tanaka Y, Kanai Y, Okada Y, Nonaka S, Sen Takeda Harada A, Hirokawa A. (1998). Targeted disruption of mouse conventional Kinesin heavy Chain kif5B results in abnormal perinuclear clustering of mitochondria. Cell 93, 1147-1158.

Thisse C \& Thisse B. (2008). High-resolution in situ hybridization to whole-mount zebrafish embryos. Nat Protc 3:59-69.

Thisse B \& Thisse C. (2004). Fast Release Clones: A High Throughput Expression Analysis. ZFIN Direct Data Submission (http://zfin.org).

Trejo H, Lecuona E, Grillo D, Szleifer I, Nekrasova O, Gelfand V, Sznajder J. (2010). Role of kinesin light chain-2 of kinesin-1 in the traffic of Na,K-ATPase-containing vesicles in alveolar epithelial cells. FASEB J. 2010 Feb;24(2):374-82. 
Vainzof M, Ayub-Guerrieri D, Onofre PC, Martins PC, Lopes VF, Zilberztajn D, Maia LS, Sell K, Yamamoto LU. (2008). Animal models for genetic neuromuscular diseases. J Mol Neurosci 34(3):241-8. Review.

Valdmanis P, Meijer I, Reynolds A, Lei A, MacLeod P, Schlesinger D, Zatz M, Reid E, Dion P, Drapeau P, Rouleau G. (2007). Mutations in the KIAA0196 gene at the SPG8 locus cause hereditary spastic paraplegia. Am J Hum Genet 80(1):152-161.

Valenzuela JI, Jaureguiberry-Bravo M, Couve A. (2011). Neuronal protein trafficking: Emerging consequences of endoplasmic reticulum dynamics. Mol Cell Neurosci 48(4):269-277.

Verhey K \& Hammond J. (2009). Traffic control: regulation of kinesin motors. Nat Rev Mol Cell Biol 10: 765-777.

Visel A, Blow M, Li Z, Zhang T, Akiyama J, Holt A, Plajzer-Frick I, Shoukry M, Wright C, Chen F, et al. (2009). ChIP-seq accurately predicts tissue-specific activity of enhancers. Nature 457, 854-858.

Voeltz G, Rolls M, Rapoport T. (2002). Structural organization of the endoplasmic reticulum. EMBO Rep 3(10):944-950.

Voeltz G, Prinz W, Shibata Y, Rist J, Rapoport T. (2006). A class of membrane proteins shaping the tubular endoplasmic reticulum. Cell 124(3):573-586.

Wang K, Li M, Hakonarson H. (2010). ANNOVAR: Functional annotation of genetic variants from next-generation sequencing data. Nucleic Acids Res., 38, e164.

Weiner A, Scampoli N, Calcaterra N. (2012). Fishing the molecular bases of Treacher Collins syndrome. PLoS One 7(1):e29574.

Yip Y, Pernigo S, Sanger A, Xu M, Parsons M, Steiner R, Dodding M. (2016). The light chains of kinesin-1 are autoinhibited. Proc Natl Acad Sci U S A. 1;113(9):2418-23.

Zanetti G, Pahuja K, Studer S, Shim S, Schekman R. (2012). COPII and the regulation of protein sorting in mammals. Nat Cell Biol 14(1):20-28.

Zhao X, Alvarado D, Rainier S, Lemons R, Hedera P, Weber C, Tukel T, APak M, et al. (2001). Mutations in a newly identified GTPase gene cause autosomal dominant hereditary spastic paraplegia. Nat Genet 29(3):326-331.

Zhu P, Soderblom C, Tao-Cheng J, Stadler J, Blackstone C. (2006). SPG3A protein atlastin-1 is enriched in growth cones and promotes axon elongation during neuronal development. Hum Mol Genet 15(8):1343-1353. 
Zhu H, Lee H, Tong Y, Hong B, Kim K, Shen Y, Lim K, Mackenzie F, Tempel W, Park H. (2012). Crystal structures of the tetratricopeptide repeat domains of kinesin light chains: insight into cargo recognition mechanisms. PLoS One. 7(3):e33943.

Zuchner S, Wang G, Tran-Viet K, Nance M, Gaskell P, Vance J, Ashley-Koch A, Pericak-Vance M. (2006). Mutations in the novel mitochondrial protein REEP1 cause hereditary spastic paraplegia type 31. Am J Hum Genet 79(2):365-369. 